UNIVERSIDADE DE BRASÍLIA

MESTRADO PROFISSIONAL EM ARTES - PROFARTES

UNB/UDESC

LANA COSTA FARIA

IMAGEM EM CENA E CORPO QUE DANÇA:

POÉTICAS PEDAGÓGICAS

BRASÍLIA/DF

2016 


\title{
IMAGEM EM CENA E CORPO QUE DANÇA: POÉTICAS PEDAGÓGICAS
}

\author{
Dissertação apresentada à Banca examinadora \\ da Universidade de Brasília, como exigência \\ parcial para obter o título de Mestre em Artes.
}

Orientador: Prof. Dr. Jorge das Graças Veloso 
IMAGEM EM CENA E O CORPO QUE DANÇA:

POÉTICAS PEDAGÓGICAS

BANCA EXAMINADORA

Prof. Dr. Jorge das Graças Veloso (PROFARTES/UNB)

ORIENTADOR

Profa. Dra. Irene Tourinho (PP-GA/UFG)

MEMBRO EXTERNO

Prof. Dr. José Mauro Barbosa Ribeiro (PROFARTES/UNB) MEMBRO INTERNO

Profa. Luzirene Rocha SEE- DF

SUPLENTE MEMBRO EXTERNO 


\section{AGRADECIMENTOS}

A minha família. A meu filho Pedro e a minha mãe, meus irmãos, minha sobrinha, pelo amor, educação e compreensão.

Ao orientador deste trabalho, Dr. Jorge das Graças Veloso, pela dedicação, paciência e seriedade.

À direção, aos funcionários e aos inúmeros amigos do Centro de Estudo e Pesquisa Ciranda da Arte, em especial a Luz Marina de Alcântara e Henrique Lima Assis, pelo incentivo, compreensão e apoio.

Às professoras colaboradoras deste trabalho, Ana Paula Blotta, Alice Assis, Cláudia Cardoso, Mônia Araújo e Itana Fleury, pela paciência, seriedade e dedicação e pela oportunidade de desenvolver essa prática educativa.

À UDESC, à UNB, aos professores do Mestrado em Artes/Profartes, pelo que me ensinaram. Em especial ao Professor José Mauro Barbosa Ribeiro, pela paciência, dedicação e carinho pelo grupo.

Aos colegas do Mestrado, especialmente a Maria Cristina Silva e Luciana Maria Rodrigues Gresta.

Gratidão à família Arakawa - Ana Maria, Mitisu e Henrique, que me acolheram com carinho.

Aos inúmeros amigos e parceiros, pelo carinho e força: Ana Rita da Silva, Luz Marina de Alcântara, Noeli Batista dos Santos, Henrique Lima Assis, Lenir Amaral, Franco Pimentel e, particularmente, a uma grande amiga arte educadora, Vânia Maria Noleto Moraes (in memoriam), que me incentivou a seguir o caminho da arte educação. 
Buscar um código no espaço múltiplo da cena é mergulhar na sequência temporal na linha evolutiva do pensamento simbólico e em seu sentido poético. A dança e o drama encontram-se no vértice de um triângulo cuja base é o indivíduo e a sociedade em que vive, na concretude dos corpos que coexistem. $O$ homem se comunica por meio de sinais, signos, símbolos, ícones, jornais, revistas, pinturas, música, dança, fofocas, filmes, palavras e gestos. A realidade da ação significativa é a realidade que conhecemos, a vida da única maneira possível de ser tocada, sentida, pensada, a não ser pelo corpo

(MOMMENSOHN, 2006, p.105). 


\section{RESUMO}

Esta investigação se propõe levar para a cena um processo criativo do corpo cênico, partindo de uma reflexão - gerada por inquietações e problemáticas vividas por professores no espaço escolar - sobre o universo da dança, no qual se identificou a dificuldade de viabilizar uma prática educativa que propiciasse comunicação e diálogo com o universo simbólico do estudante. Sendo assim a perspectiva deste trabalho é contribuir para a aproximação de professores e alunos, de modo a propiciar uma prática reflexiva que dê ao aluno a oportunidade de ser sujeito da construção do conhecimento em dança, estimulando, consequentemente, sua intervenção na realidade. Ao partir do pressuposto de que as imagens têm influenciado os modos de viver, sentir e perceber o mundo contemporâneo e de que a escola não pode silenciar ante esse processo de subjetivação, o objeto deste estudo centra-se nas repercussões, nos impactos e nos desdobramentos de uma prática educativa em dança - a partir de narrativas de imagens - para uma formação continuada de professores que lhes possibilite comunicar e dialogar com os estudantes através de produções de corpos em cena. Ao ampliar as visualidades para além do contexto da dança, abrangendo o universo simbólico mais amplo proporcionado pela cultura visual, um conjunto de aprendizagens envolvendo as narrativas de imagens foi planejado e desenvolvido com um grupo de professoras de dança de escolas públicas, visando tornar possível a tomada de consciência corporal e a criação e recriação de movimentos capazes de inserir vozes ausentes nas vivências em dança no contexto escolar. Com essas narrativas visuais criaramse novas imagens passíveis de informar, formar, dialogar e comunicar com o universo do aluno; configurar e construir traços identitários. O processo de criação em dança, autoral e dialógico, elaborou-se com base nos elementos estruturais do movimento de suas formas externas e das dimensões mental e emocional, segundo estudos da Coreologia, princípios de Rudolf Laban e jogos corporais propostos por Angel Vianna. Centrado nas narrativas de imagens, gerou escuta e reflexão a partir da produção "Poéticas do corpo em cena", construindo diálogos com o corpo, com a dança e com a sociedade. A investigação foi composta por cinco professoras colaboradoras que atuam na rede estadual do ensino de dança, perfazendo sete cenas no processo criativo. Processo criativo este que promoveu diálogos e conexões com som, imagem e corpo na cena, reverberando composição instantânea de uma arte efêmera. Todo este processo foi registrado em fotos, filmado pelas professoras, compostos por narrativas orais das imagens e gravado e os relatos inseridos em diário de bordo em forma de narrativas individuais sobre as impressões obtidas. Consideramos que esta abordagem se mostrou capaz de estimular e suscitar a discussão, a reflexão e a interpretação crítica das especificidades do universo ampliado da dança e de promover o reencantamento do espaço escolar. As imagens trazem concepções estéticas de danças que não são neutras, mas perpassam e integram ideias, valores, relações de poder das estruturas sociais em que se realizam, sendo o ensino de dança na escola um espaço de crítica, interpretação e criação. Assim, esta é uma prática pedagógica plena de abertura para novas experimentações e produções interativas, visto ser um processo do qual participam subjetividades diversas, com suas histórias, de desejos e experiências que conformam a singularidade de cada um. Transformam a sala de aula em um espaço de investigação, aprendizagem e compartilhamento de experiências.

Palavras-chave: Processo criativo. Imagem. Escuta. Corpo em cena. Prática educativa. 


\begin{abstract}
This research aims at taking to the scene a creative process of scenic body, starting from the reflection - generated by the concerns and problems experienced by teachers at school - on the dance universe, in which we identified difficulties in visualizing an educative practice that provided communication and dialogue with the student's symbolic universe. Therefore, this research aims to contribute to approach teachers and students by developing a reflexive practice that gives the students the opportunity to be part of the construction of a dance knowledge and consequently stimulate their intervention in the reality. Assuming that images have influenced the way people live, feel and perceive the contemporary world as well as that the school cannot silence itself while facing this subjectivation process, the object of this study focuses on the impacts and consequences of an educational practice in dance. It looks at imagery narratives for continued training of teachers to enable them to communicate and interact with students through bodies' productions on the scene. By expanding the visual arts beyond the dance context and encompassing the broader symbolic universe provided by the visual culture, a set learning involving narrative images, planned and developed with a group of public school dance teachers. It intends to make body awareness and the creation and recreation of movements capable of contextualizing absent voices in dance experiences in the school context. With these visual narratives, new images are created to inform, form, dialogue, and communicate with the student universe; they are configured and built up identifying features. The process to create dance, copyright and dialogic is prepared based on structural elements of movement from their external forms and from mental and emotional dimensions, according to Choreology studies, Rudolf Laban's principles and body games proposed by Angel Vianna. Once it is focused on narrative images, it generates listening and reflection from the production "Body Poetry on stage" builds dialogues with body, dance and society. The research consisted of five teachers, who teach dance in public schools. They all made seven scenes in the creative process, which promoted dialogues and connections with sound, images and body during the scene, reverberating instant composition of an ephemeral art. All this process was photographed and filmed by the teachers. It was also recorded and included in the study individual oral narratives of the images. We consider that this approach was able to stimulate and evoke discussion, reflection and a critical interpretation of the expanded dance universe specificities as well as to promote re-enchantment of the school space. The images bring aesthetic conceptions of dances that are not neutral, but that permeate and integrate ideas, values, and power relations of social structures where they take place. It makes dance teaching in schools a space for critic, interpretation and creation. Thus, this is a sufficient pedagogical practice opened to new exploratory and interactive productions. This process embraces different subjectivities, which present stories, desires and experiences able of transforming their own singularities. It transforms the classroom in a space for investigation, learning and sharing experiences.
\end{abstract}

Keywords: Creative process. Image. Listening. Body in scene. Educational practice. 


\section{LISTA DE FIGURAS}

Figura 1 - Gráfico do Processo Criativo em Dança ...............................................26

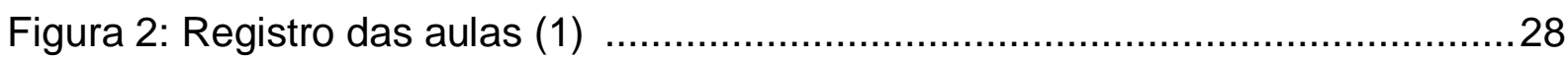

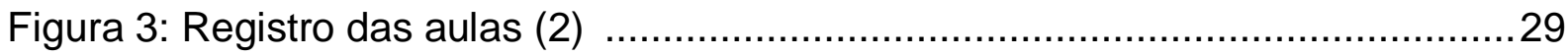

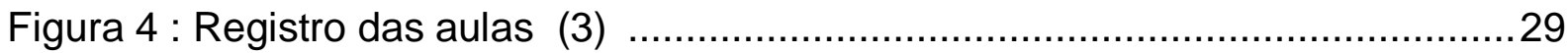

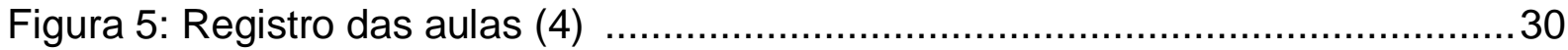

Figura 6: Movimento - Estrela máxima da dança ...................................................... 31

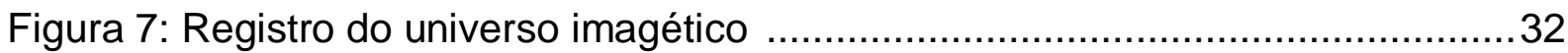

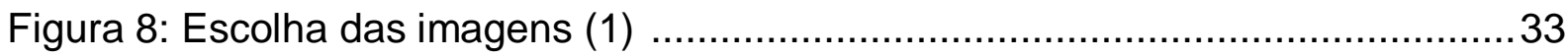

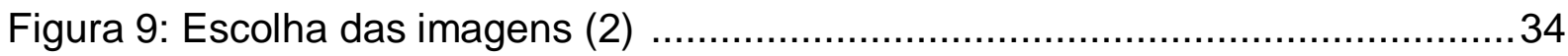

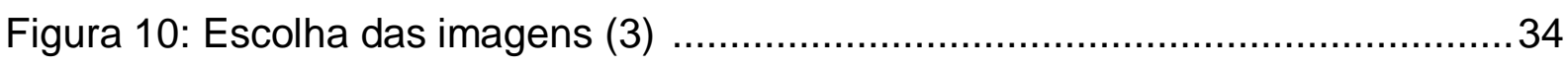

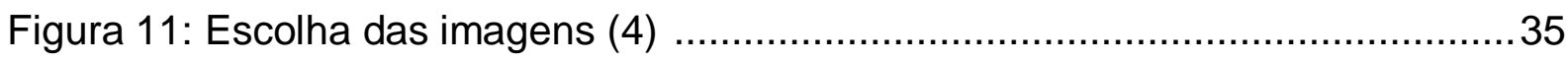

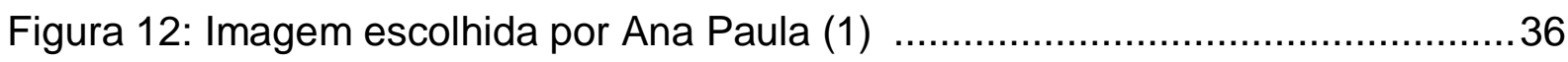

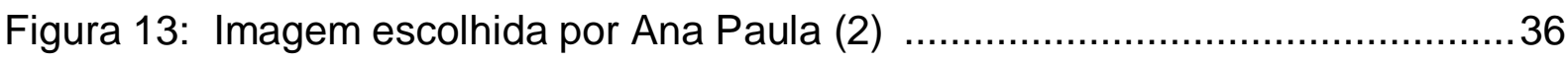

Figura 14: Imagem escolhida por Ana Paula (3) .............................................. 37

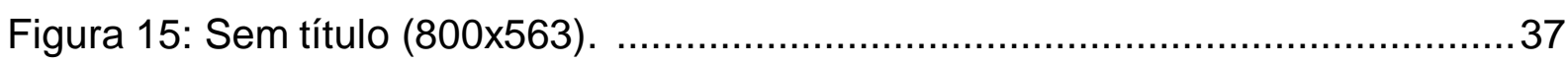

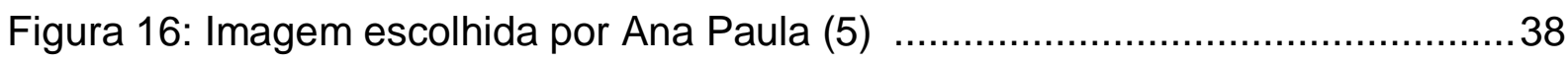

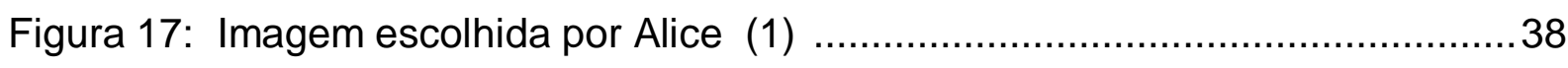

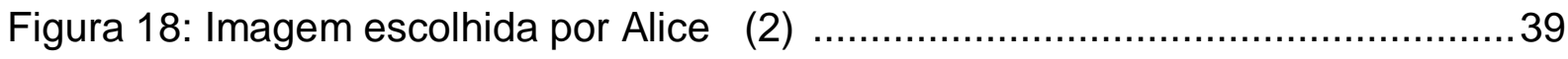

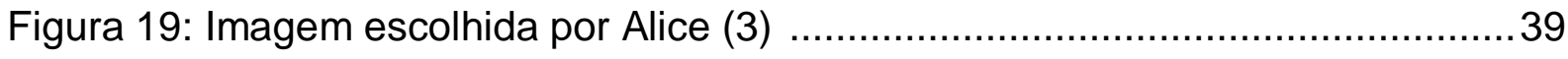

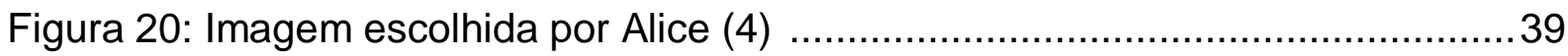

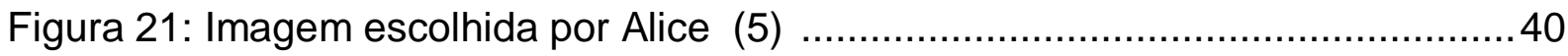

Figura: 22: Imagem escolhida por Cláudia (1) ……................................................ 40

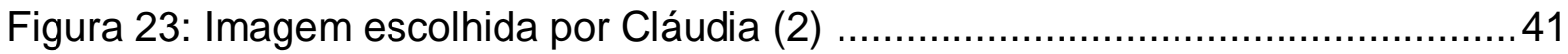

Figura 24: Imagem escolhida por Cláudia (3) ………............................................. 41

Figura 25: Imagem escolhida por Cláudia (4) ……............................................... 42

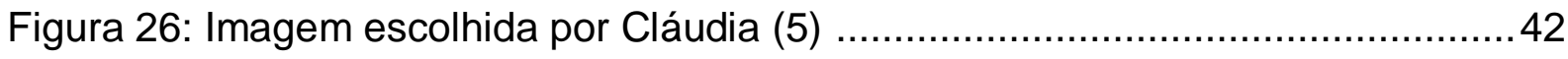

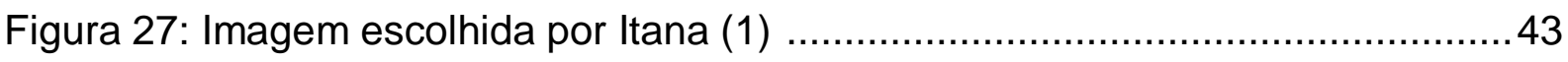

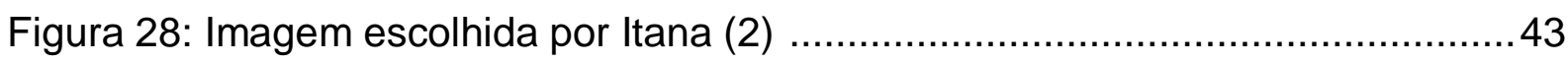

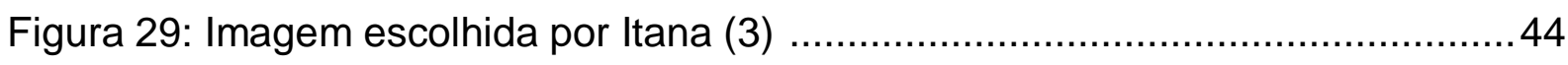

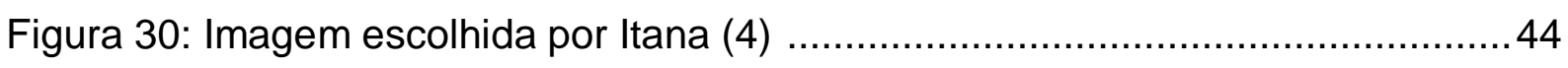

Figura 31: Antropofagia (1929) Tarsila do Amaral .................................................. 44 
Figura 32: Imagem escolhida por Itana (6) 45

Figura 33: Imagem escolhida por Mônia (1) 45

Figura 34: Imagens de Poteiro 648×558 - Imagem escolhida por Mônia (2) .46

Figura 35: Imagem escolhida por Mônia (3) 46

Figura 36: Imagem escolhida por Mônia (4) 47

Figura 37: Imagem escolhida por Mônia (5) 47

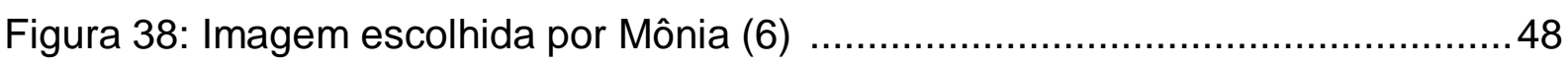

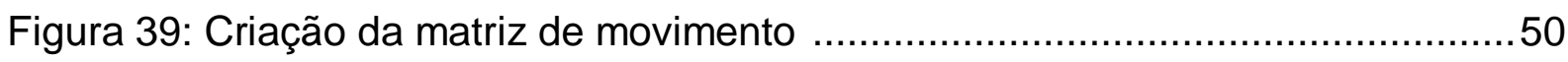

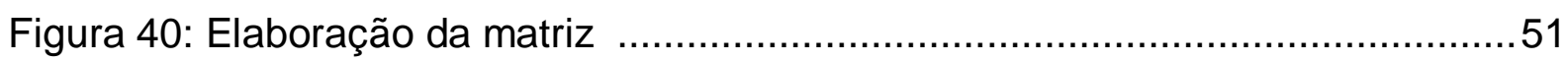

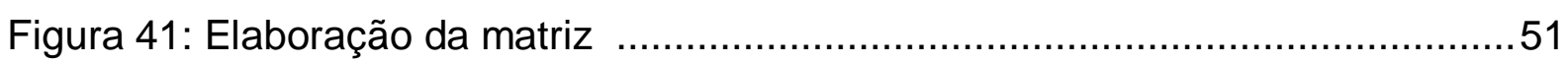

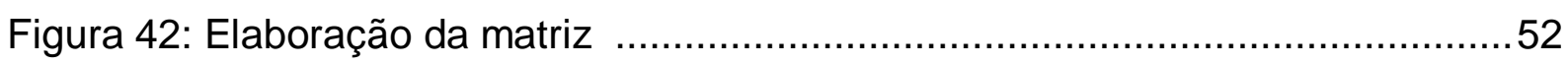

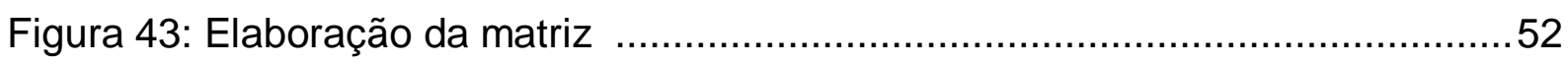

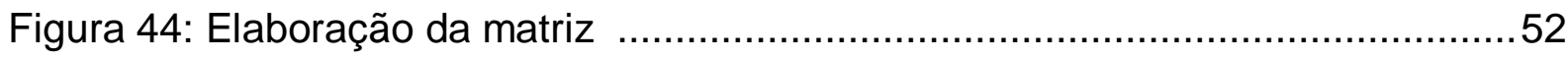

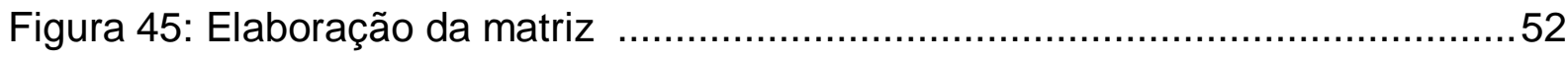

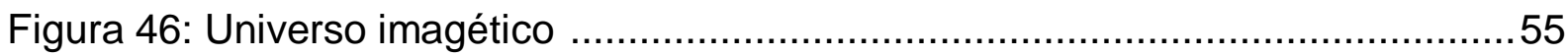

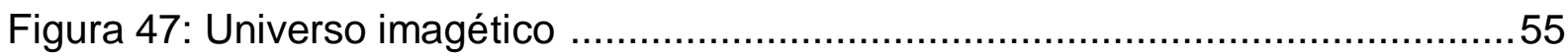

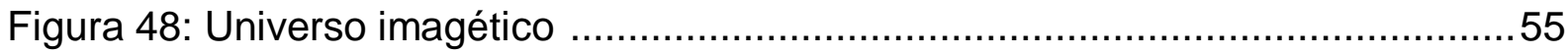

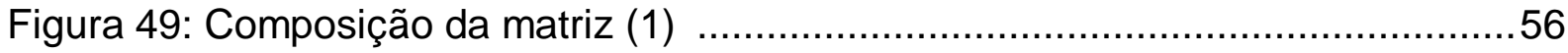

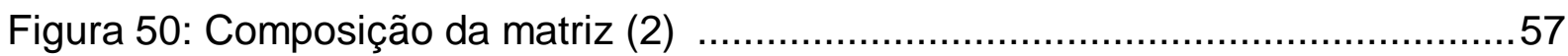

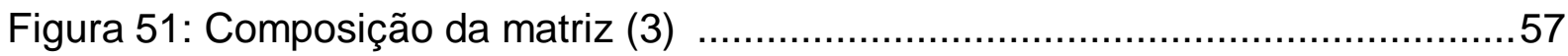

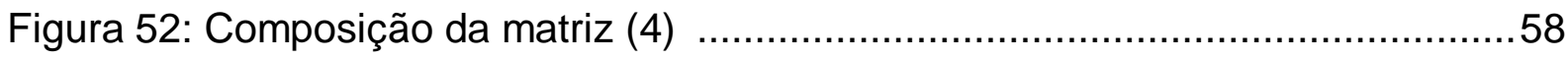

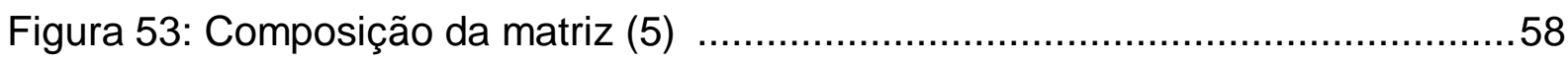

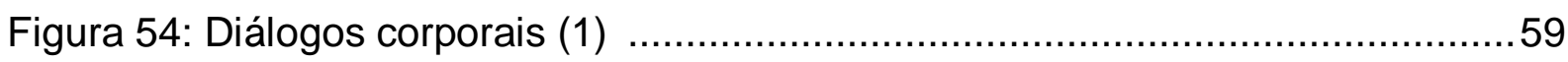

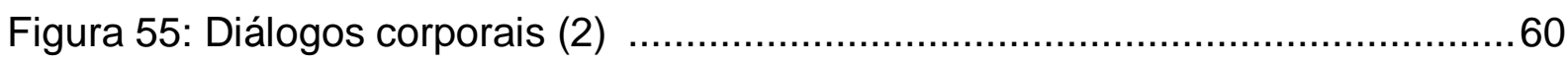

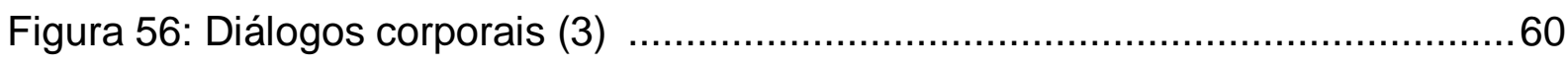

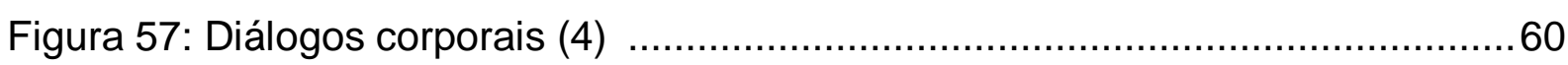

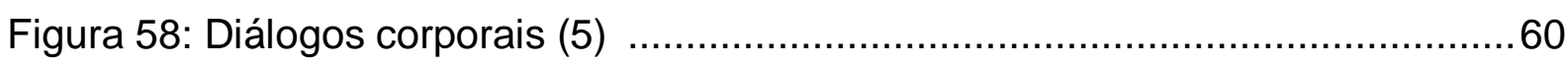

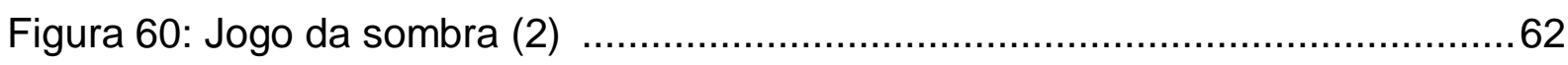

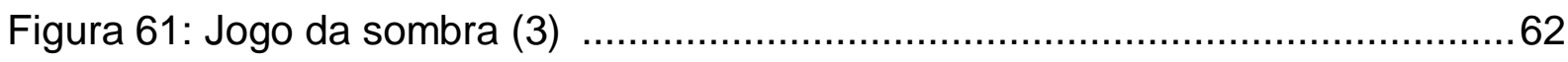

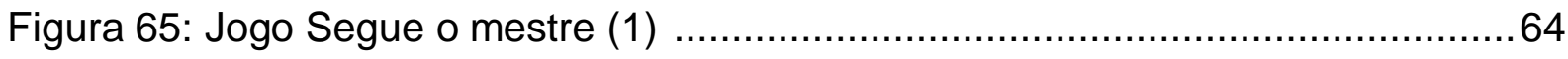

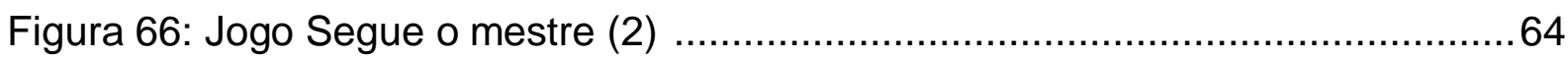

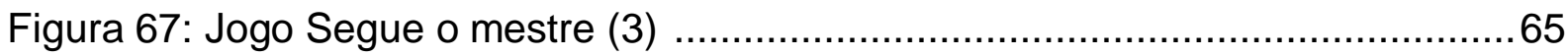

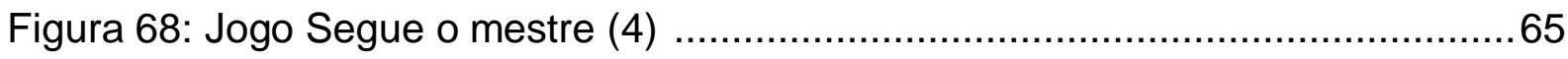

Figura 69: Individuais simultâneas (1) ..........................................................66

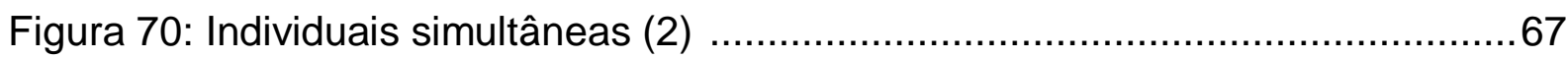

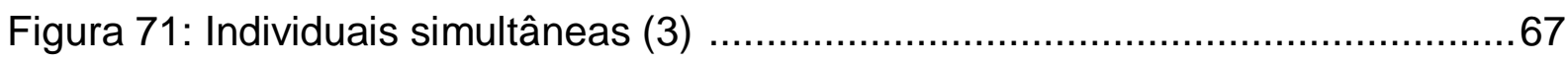




\section{SUMÁRIO}

1 INTRODUÇÃO

1.1 Interface das visualidades e a dança: ver e ser visto .................................14

2. TRILHANDO CAMINHOS: PROPOSIÇÕES DE UMA PRÁTICA EDUCATIVA EM DANÇA

2.1 Processo Criativo em Dança para a Ação Cênica .........................................26

2.2 Reflexões do Processo Criativo …………….......................................... 30

2.3 Elaboração das Matrizes de Movimento e o Corpo em Cena ...........................49

2.4 "Poéticas do Corpo em Cena" .....................................................................54

3 CONCLUSÕES POSSÍVEIS PARA UMA PROPOSIÇÃO EM DANÇA .................68

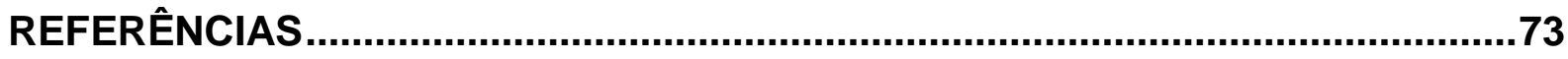

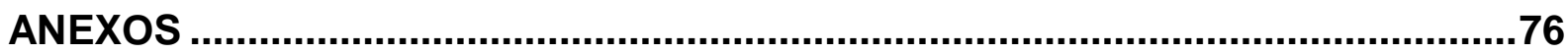


Para situar o presente trabalho, inicio descrevendo minhas experiências, escolhas, inquietações, interesses, no percurso da docência e na trajetória como professora, artista e pesquisadora. Apresento as motivações que me fizeram buscar caminhos, na investigação do mestrado, no estudo do que está por conhecer.

Iniciei minha vida acadêmica no curso de licenciatura em Educação Física na Universidade Estadual de Goiás - UEG. Durante o curso, meu interesse foi, inicialmente, despertado pela Ginástica Rítmica (1981), me levando a fazer o curso de Pós-Graduação em nível de especialização Lato Sensu, quando conheci a metodologia de Call Worf e a rítmica de Emile Jaques Dalcroze, teóricos da música e do movimento. Depois, especializei-me em Educação (1989) e Educação Motora (1990), também na Escola Superior de Educação Física de Goiás- ESEFEGO/UEG.

Em seguida, iniciei meus estudos sobre dança, ingressando no Grupo "Dançarte" (1984 - 1987,) da Universidade Federal de Goiás. A partir dessa experiência, comecei a estudar dança educação e a fazer aulas de diversos estilos de dança. Esse estudo no grupo de pesquisa contribuiu para minha formação inicial.

Participei de vários cursos no espaço Caleidos Arte Ensino, em São Paulo, de 2004 a 2008; na Quasar Cia de Dança em Goiânia (2005, 2010, 2014); no trabalho com a técnica Klauss Vianna, com Angel Vianna, em Goiânia (2009). Tomei parte em Congressos, Seminários em Artes Cênicas, Cultura Visual em Goiânia (2006 2009, 2015); Seminários e Simpósios em Educação - Encontro Estadual de Didática e Práticas de Ensino (EDIPE) - em Goiânia (2011, 2015); mostras: o I e o II Festival Latino-Americano de Arte e Cultura (FLAAC/UNB) em Brasília; várias edições do Festival de Arte da cidade de Goiás, de Educação Estética (2002 - 2004, 2010, 2013); encontros na Federação Nacional dos Arte Educadores do Brasil (CONFAEB) em 2003, 2004, 2007 - 2011 e 2015 em várias cidades do Brasil; encontros sobre Laban no Museu de Arte Moderna - MAM- RJ ( 2002 , 2004), Encontro da Ci-Brasil no 3th e 9th Dance and the child internacional na UNICAMP(1996) e na Faculdade Social da Bahia FSBA (2003), dentre outros nesta área de conhecimento.

Participei, ainda, da comissão organizadora de eventos Folia de Reis, da Secretária da Cultura - SECULT, em Goiânia (2014 - 2016); de vários Seminários do Ensino de Arte: desafios e possibilidades (2007 - 2013), da coordenação de oito mostras de Dança das escolas estaduais (2004 - 2013), promovidas pelo Centro de 
Estudo e Pesquisa Ciranda da Arte, da Secretaria da Educação do Estado de Goiás, em Goiânia.

Simultaneamente tenho desenvolvido meus estudos em dança educação: o Sistema de Rudolf Laban, seus estudos do movimento humano e o Método Klauss Vianna e Ivaldo Bertazzo, além de outros teóricos que têm contribuído para o ensino de dança. Tomo também como referências os estudos teóricos das educadoras, artistas e pesquisadoras Ana Karenina (2009), Angel Vianna ( 2007), Isabel Marques (2000, 2003, 2012), Jussara Miller (2007), Klauss Vianna (2005), Lenira Rengel (2003, 2008), Marcia Strazzacappa (2007), Maria Mommensohn e Paulo Petrella (2006). Toda essa experiência veio a contribuir para a minha pesquisa, pois foi me oportunizado vivenciar diferentes práxis pedagógicas em dança com diferentes processos metodológicos e técnicas.

Iniciei minha atuação em grupos de produção artística em dança no Grupo "Dançarte", da UFG, dirigido por Lenir de Lima, a quem já fiz referência aqui. Logo nos unimos com um "Grupo Teatro Universitário" da UFG (1987), dirigido por Lenir Lima e Carlos Fernando. Participei de um dos grupos na criação do espaço cultural da Secretaria da Cultura de Goiânia "Martim Cererê" (1988), tendo como diretores Mauri de Castro e Marcos Fayad; atuei como intérprete criadora em um grupo formado por professores de dança "Araticum"(2012), com trabalhos destinados ao público infantil. Envolvi-me na criação de um grupo de pesquisa em dança (2014) sobre memória e história de vida com professores da rede estadual de ensino, fruto de um curso de formação. Foi produzido um espetáculo com intérpretes criadores "Rede, corpo e memória em dança", uma composição instantânea, ainda em processo de pesquisa. Esse estudo veio contribuir com minha atual investigação.

Minha experiência na docência iniciou-se em uma escola regular por um ano; depois atuei na escola de Arte Educação da Secretaria Educação do Estado de Goiás "Escola de Arte Veiga Valle" (1984 - 2002), de ensino não formal. Ministrei para crianças e adolescentes a disciplina Dança Educação, Jazz, Contemporâneo e História da dança. Atuei também como coordenadora pedagógica de dança e participei da direção geral de inúmeros espetáculos. Nesse espaço, me foi oportunizado, por vários anos, aprofundar meus conhecimentos, frequentando eventos e cursos nesta área de atuação. Toda minha experiência em arte educação e a base de minhas investigações na área foram ali vivenciadas. Atuei como professora de dança efetiva no curso de graduação em Educação Física no Campus 
avançado de Catalão - UFG (1990 - 1999), com a disciplina Dança Educação e Movimento Criativo; atuei no ensino de arte em escolas da Secretaria Municipal de Educação de Goiânia na rede rural no ensino formal (2000 - 2004). Atualmente estou à disposição da Secretaria de Cultura de Goiânia, atuando no Centro Livre de Artes (CLA) com aulas de dança criativa na oficina integrada.

Como professora convidada, colaborei no projeto de extensão de Arte educação na Universidade Federal de Goiás, no Centro de Estudo e Pesquisa Aplicado à Educação (CEPAE), na sistematização e na elaboração de vários musicais (2000 - 2011), com uma equipe de arte multidisciplinar. Todas essas experiências me oportunizaram estabelecer conexões entre 0 universo dança/educação e o espaço escolar. Também atuei como tutora em três disciplinas no Plano Nacional de Formação de Professores (EAD/PARFOR), no curso de Licenciatura de Artes Visuais da UFG (2007, 2010). Aproximei-me dos estudos da Cultura Visual, ao participar de Encontros, Colóquios e Seminários. Esse foi o início do meu interesse pelos estudos da cultura visual.

Em 2002 fui convidada a trabalhar com capacitação de professores no Centro de Estudo e Pesquisa Ciranda da Arte, instituição vinculada à Secretaria de Educação do Estado de Goiás. Iniciei as atividades, fazendo acompanhamento dos Projetos de Atividades Educacionais Complementares (PRAECs), que consistiam no desenvolvimento de projetos na área de arte nas unidades escolares da rede estadual, nas quatro linguagens artísticas, realizados no contraturno das aulas regulares. Esses projetos reverberaram na proposição de cursos de capacitação para professores de Dança (2002 - 2010). Nesse Centro me envolvi também na criação e no desenvolvimento de vários cursos e grupos de estudos da área de dança como apoio pedagógico para os professores que atuam em sala de aula.

Outras atividades que considero relevantes no meu percurso formativo e profissional foram a elaboração da Matriz Curricular em Arte e as Sequências Didáticas de Dança (2008); a implementação curricular do ensino de Arte na Rede Estadual de Educação de Goiás (2009, 2010); a organização de várias mostras de dança (2004 2012); e trabalhos desenvolvidos nas escolas pelos professores da rede.

Essa trajetória formativo-profissional gerou observações e indagações que me instigaram a realizar esta pesquisa, propondo uma prática educativa em dança no espaço escolar. Ao desenvolver o trabalho no Centro de Estudo e Pesquisa "Ciranda da Arte", no processo de discussão e elaboração do Currículo de Artes do Estado de 
Goiás, me aproximei das outras linguagens, em especial as artes visuais. Para a elaboração, optamos pela concepção de um currículo culturalista, de acordo com Tomaz Tadeu da Silva (2011), que é considerado pós-crítico. Segundo ele, o currículo deve ser pensado para atender às necessidades a partir das diferenças, valorizando o que cada cultura afirma como importante para sua comunidade.

Ao longo de 11 anos, venho ministrando cursos de formação na rede estadual de Educação e sempre me deparei com as dificuldades dos professores de dança para viabilizar uma prática pedagógica em que dialoguem e se comuniquem com seus alunos. A escuta das inquietações sobre o currículo me levou à aproximação com a cultura visual, que apresenta reflexões sobre o uso de imagens em sala de aula. Em minhas aulas as imagens se tornaram presentes, e, ao expor conteúdos e o seu universo estético, passei a contextualizar, por meio de imagens, os elementos de compreensão e interpretação crítica. Assim surgiu a ideia de ampliar as visualidades para além do universo da dança, abrangendo o universo simbólico mais amplo proporcionado pela cultura visual, com imagens da arte, da publicidade, do cinema, da propaganda e das demais visualidades.

Considero que a minha relação com a cultura visual também está diretamente ligada a minha memória de fatos de minha infância, uma vez que cresci ao lado de um pai fotógrafo, em uma cidade pequena no interior, Bela Vista de Goiás. As imagens foram referências, gravadas em toda minha vida, fotografadas no quintal de casa, no ateliê de fotos de meu pai, em casamentos, festas de família, eventos sociais, políticos e culturais na cidade, na escola, nas fazendas, nos funerais e nas quermesses. Até o processo de revelação das imagens eu acompanhava, observando-o. Portanto, meu fascínio pelas imagens se deve a um imenso acervo de fotos que, por cinco gerações seguidas, incluem registros de memórias, vidas, experiências.

Trazer as imagens para o cotidiano do estudante oferece a oportunidade de escolhas que permitam identificar como vemos e somos vistos na contemporaneidade. Como comenta Tourinho (2011, p.6):

Imagens são artefatos que articulam informações, conhecimentos, entretenimento e comunicação. Elas influenciam, direcionam, alteram e transformam sentidos e significados de experiências de papéis sociais de alunos e professores. Desenhando nossos jeitos de ser, sentir e agir, as 
imagens nos formam, construindo e configurando traços identitários que nos identificam, e nos representam.

A cultura visual discute as visualidades e as visualizações e seus usos na vida social, repleta de imagens televisivas, celulares, fotografias, outdoors, roupas, vitrines, entre outros.Com a presença das imagens na vida do aluno, ele vê o que quer e aquilo que não quer ver. Elas estão diretamente relacionadas não só à questão de ver, mas também de ser visto - dois focos em conexão. Consequentemente, elas têm influenciado nos modos de viver, sentir e perceber o mundo contemporâneo. $E$ a escola não pode silenciar.

De acordo com a cultura visual, as imagens possibilitam acesso ao mundo de experiências, sonhos, memórias - ao universo do eu e do outro. Como menciona Tourinho (2011, p.4 ), "as imagens contam de nós, dos outros, para nós, para os outros". A escola pode contribuir para a formação humana dos alunos a partir dessa relação; por isso, proponho a interface do universo imagético com a dança nesse espaço.

\subsection{Interface das visualidades e a dança: ver e ser visto}

Os meios de comunicação veiculam informações que antes eram prerrogativa principalmente da família e da escola, e não só alteram o tipo de acesso, mas passam a ser um instrumento de socialização, construindo valores, modos de ser e padrões de comportamento. Ao circundar o saber na atualidade, os meios de comunicação exigem das gerações esforços para incorporar valores e hábitos de produção de conhecimento que estão além do âmbito da família e da escola, os quais antes legitimavam o saber. Sobre isso, Fiorentini e Carneiro (2002, p.80) argumentam que

os alunos vivem hoje uma realidade inteiramente nova para uma parcela considerável de professores. A imagem ocupa todos os espaços no interesse de crianças e jovens. Como transmissora de cultura e geradora de conhecimento, a escola precisa interpretar os fatos do dia-a-dia, pois não pode mais ficar distanciada dos meios de comunicação. Elas exercem hoje uma influência decisiva na educação de crianças e jovens.

Com efeito, a utilização da imagem como meio de comunicação e diálogo com 
a escola passa a ser um instrumento para atender a uma finalidade que consiste no exercício da cidadania, o que é, sem dúvida, um caminho possível (LUCKESI, 1986). Os meios de comunicação tornaram-se ferramentas imprescindíveis à vida social, política, profissional, cultural e educacional na atualidade.

Minha proposta de investigação, a partir do diálogo entre cultura escolar e cultura midiática, é possibilitar aos educandos a comunicação mediada pelas imagens, de modo que esta seja significativa e crie sentidos para o envolvimento e o desenvolvimento durante a práxis pedagógica da dança. Espero abrir, assim, possibilidades ao estudante para experienciar, vivenciar e valorizar artefatos e manifestações culturais de grupos e segmentos sociais denominados hegemônicos, para operar com as vozes ausentes, consideradas por Santomé (1998, p.131), "as culturas ou vozes dos grupos sociais minoritários e/ou marginalizados, que não dispõem de estruturas importantes de poder, costumam ser silenciados, ou mesmo estereotipados e deformados para anular suas possibilidades de reação". Acredito que elas, as imagens, são capazes de estimular e suscitar a discussão, a reflexão e a interpretação crítica das especificidades do universo homossexual, feminino, indígena afro-brasileiro, da classe trabalhadora, dos sujeitos com necessidades especiais, da cultura infanto-juvenil; e de promover o reencantamento do espaço escolar.

Proponho nesta investigação uma educação ativa, crítica e solidária, que colabore para a reconstrução da realidade, valorizando os conteúdos culturais da comunidade em que se insere a escola, que deve respeitar e valorizar a identidade social dos diferentes grupos humanos. A aceitação da própria identidade é uma das principais condições para saber valorizar a dos demais. Ao lidar com esse contexto, ressalta-se a relação entre as imagens e a identidade, como afirma Martins (2011a, p.16-17):

As marcas culturais que constroem nossas identidades servem para rachar, fraturar a solidez das nossas convicções. Somos infiltrados e invadidos pelos elementos das culturas que nos constituem e que vão, gradativamente, nos transformando, assim como deixamos vazar nossas diferenças pelas frestas e rachaduras dos e entre os diversos papéis e posições de sujeito que experimentamos. Nesse sentido, o conceito de diferença é elemento fundamental nas discussões sobre os processos culturais pós-modernos. A premissa fundamental que orienta essas discussões é a de que "não se pode estabelecer uma hierarquia entre culturas humanas [pois] todas as culturas são epistemologicamente e antropologicamente equivalentes" (Silva, 2002, p. 86). A partir dessa premissa, compreendemos que "não é possível estabelecer nenhum critério transcendente pelo qual uma determinada cultura possa ser julgada superior a outra" (ibidem). 
Trabalhar com as imagens e discutir as diferenças pode orientar nossas práticas e reflexões pedagógicas para o respeito às individualidades e às diferenças do outro, sem criar o juízo de valor de alta e ou baixa cultura. Na relação com o outro nós nos reconhecemos e nos reconstruímos.

Presentes na vida do educando, as imagens trazem concepções estéticas de danças que não são neutras, inocentes, mas que perpassam e integram ideias, valores, relação de poder das estruturas sociais em que se realizam. Circulam e articulam sentidos que devem ser discutidos em sala de aula. A escola tem um papel social, como relata Strazzacappa (2007, p.11) "aquilo que as crianças sabem de dança não pode se limitar ao que aparece na televisão. O papel da escola é incentivar a criança a re-significar, trazer outros modelos", nos quais possam refletir sobre suas práticas e contextualizá-las, não simplesmente reproduzir. O ensino de dança na escola é um espaço de discussão e reflexão crítica sobre o que dançam, como, onde, quando e por que dançam. Uma discussão inesgotável entre os educadores, conforme acredita Marques (2003, p.2):

\begin{abstract}
A questão da identidade nas danças da TV: por serem moda, todos dançam a mesma coisa. A moda e o modismo são imperativos sócio-econômicoculturais e devem, sem dúvida, ser discutidos com mais propriedade e profundidade. Mas é notório que uma das facetas encontradas na moda, no entanto, é a necessidade de pertencimento. Será que as crianças e jovens não veem no aprendizado das danças da mídia uma forma de pertencer ao grupo, de construir uma identidade individual dentro do coletivo? - mesmo que saibamos da massificação ali presente, quem está na moda tem como resposta à sua necessidade de individualização o fato de não pertencer aos que não estão na moda.
\end{abstract}

Essa realidade preocupa o professor em sala de aula, tornando-se motivo de embates e conflitos de problematização e de desconstrução das práticas já existentes, promovendo diálogos entre o corpo, a dança e a sociedade. Isso me fez pensar sobre qual o papel do arte educador no espaço escolar e sobre como esse conhecimento específico em dança tem significado e se torna significativo para o educando. Os alunos já nascem nessa realidade que é nova para nós. Para os professores, hoje, a tecnologia e seus impactos sobre processos e instituições sociais, como a educação, exigem de todos uma adaptação aos modos de ver, ler e aprender.

A sociedade atual, predominantemente midiatizada, estabelece um sistema escolar que favorece conhecimentos e competências para uma participação eficaz que permeie significados. Enquanto a escola se apoia na linguagem verbal e na 
escrita, as fontes sonoras e imagéticas - é incontestável - tomam espaço pela chamada civilização das imagens e do som. Analisando esse contexto, ficou clara a dificuldade de comunicação, ao fazer referências à produção da mídia. Como a influência das imagens da mídia vem reverberando no contexto desse corpo que dança? Que significados ela, a mídia, dá para o fazer artístico? Essas questões são discutidas no ensino de dança na escola? Como?

Ao analisar os relatos de professores participantes do curso de formação realizado em 2007, foi identificada a dificuldade para viabilizar uma prática educativa que propiciasse comunicação e diálogo com o universo simbólico do estudante. Segundo as professoras, a reflexão sobre o universo da dança, a partir de inquietações e problemáticas identificadas no espaço escolar, levantou a questão: a mediação, ao lidar com modelos estéticos de dança, como o funk, o break, a axé music, entre outras, tem influenciado nas suas práticas pedagógicas? A referência que esses alunos estão vivendo - funk ou break - interfere significativamente na pedagogia? Precisamos ir além, discutir e refletir sobre as repercussões e os impactos desse consumo, sobre o que ele provoca.

Esses são caminhos questionáveis. Será que os professores e a escola têm se preocupado com a forma como a prática da dança tem se aproximado das crianças, dos jovens e dos adultos nos dias de hoje? Como nos vemos e somos vistos, ao dançar? Será que sou visto e/ou escutado? Quando é oportunizada essa escuta? A escola oportuniza ao aluno ver e ser visto em algum momento do processo ensino-aprendizado em dança? Como? Onde? Quando? O que se tem discutido e refletido sobre esse consumo? Que sentido e significado têm essas imagens para o estudante que as consome? Pesquisadores discutem sobre 0 assunto, e um deles, Tourinho (2011, p.9, p.10), comenta:

\footnotetext{
Precisamos, considerar, então, as práticas de consumo acelerado de imagens, estimuladas em todas as faixas etárias, e nos impactos desse consumo que, dentre outras implicações, coincidem a felicidade a alegria, fincados em estereótipos que "materializam" o prazer, o poder, a satisfação.
}

Ao propor uma prática educativa a partir de narrativas de imagens de diversas fontes do universo visual, desde das imagens mais corriqueiras, presentes em revistas, jornais, campanhas publicitárias, logomarcas, imagens de arte, imagens de dança, entre outros, que significados atribuímos a essas imagens? Como e quando se pode provocar a reflexão da ação cênica na produção do corpo para cena? Há possibilidades, por meio das imagens da mídia e da arte, de dialogar com o universo 
simbólico dos dançantes e mediar discussões entre os diferentes espaços que ocupam no contexto contemporâneo, desestabilizando saberes?

Importa refletir sobre o significado que as imagens possuem para o fazer artístico, sobre a forma como interferem no olhar do corpo que dança e como as representações em dança, articuladas com as imagens, interferem e modificam o olhar do estudante. Olhar e ver a que elas aludem, o que mostram, omitem, transformam, gerando multiplicidades de sentidos. Como menciona Tourinho $(2011$, p. 6):

\begin{abstract}
Trabalhar pedagogicamente com imagens pressupõe refletir sobre seu poder e força polissêmica. Pressupõe, ainda, compreender que nem todos veem a mesma coisa quando olham algo e, portanto, a escola necessita refletir sobre o que vemos e porque vemos de determinada maneira. $\mathrm{O}$ papel que as imagens têm na vida cultura e, especialmente, deveriam ter na vida escolar, é colocar em cena e fazer circular a diversidade sentidos e valores que elas geram na interação com os indivíduos. As relações entre imagens, identidade e escola suscitam discussões que questionam e desestabilizam saberes.
\end{abstract}

A crescente penetração dessas formas de cultura visual e da liberdade com que elas cruzam os limites tradicionais pode ser apreciada na utilização em danças criadas e recriadas, nas imagens geradas por diversas fontes como revistas - Isto é, Caras, Veja - jornais, imagens de arte, fotografias cotidianas, catálogos, cartões postais, calendários, folders de teatro de dança e modelos estéticos de danças: uma bailarina, um capoeirista, um passista de frevo, um catireiro sapateando, um dançante de jongo, de lundu, de maracatu, de congada, de ciranda, dos orixás, entre outros. Assim, optar pela cultura visual para o ensino da dança foi uma forma de subsidiar a mediação, o diálogo com o mundo contemporâneo. Como enfatiza Martins (2011b, p.38),

professores e alunos estão diretamente expostos à cultura visual e, como tal, são vulneráveis às imagens que nos cercam. Trabalhar pedagogicamente com essas imagens, temas e questões, ajuda a entender como e porque certas influências são construídas, a desenvolver uma compreensão crítica em relação às representações da cultura visual e, sobretudo, a vivenciar e aprender um sentido de discernimento e autocrítica. Como perspectiva educativa, a cultura visual pode propiciar aos alunos e professores oportunidade para discutir e se posicionar sobre os dilemas morais, sociais e éticos que afligem e demandam a atenção da sociedade contemporânea.

Essa perspectiva pode contribuir para a aproximação de professores e alunos, de modo a propiciar uma prática reflexiva e dar ao aluno a oportunidade de ser sujeito 
de sua própria história na construção do conhecimento em dança, estimulando, consequentemente, sua intervenção na realidade. Partindo desse pressuposto, a proposta da dança e da imagem em cena vem do meu interesse em usar as narrativas para construir composições em dança do corpo em cena. Proporcionar uma escuta, aproximar-me da cultura midiática como uma possibilidade de comunicação e diálogo com o universo simbólico do aluno e oportunizar experiências estéticas. Como considera Pellegrin (2011, p.33), "experiência estética é essencial para o ensino de dança e o campo da estética lida diretamente com a sensibilidade, com a capacidade de relacionarmos com o mundo e com os outros pelos sentidos".

Assim, o foco deste estudo centra-se nas repercussões, nos impactos e nos desdobramentos da prática educativa em dança a partir de narrativas de imagens para a formação continuada de professores, que possibilite a eles comunicar-se e dialogar com os estudantes por meio de produções de corpos em cena.

O ponto de partida foi a visualização de várias fontes imagéticas com um grupo de seis professores de dança da rede estadual de ensino, com o intuito de propor um processo criativo em dança com narrativas de imagens: partindo de suas escolhas pessoais, criar uma matriz de movimento, fazendo a reflexão da ação cênica sobre a experiência de levar o corpo para cena. A investigação centra-se na linha de pesquisa "abordagem teórica e metodológica das práticas docentes", buscando, com o recorte metodológico experimental, as práticas em sala de aula. Este projeto propõe-se investigar as repercussões, os impactos e os desdobramentos que poderão gerar e reverberar na práxis pedagógica desses professores de dança que atuam no espaço escolar.

A questão central é como as imagens podem contribuir para uma prática educativa no ensino da dança e como podem nos aproximar do universo artístico do estudante. As imagens podem gerar a mediação e a discussão nos diferentes espaços que elas ocupam no contexto contemporâneo. Reforça Farina (2008, p.101, p.102):

As imagens e os discursos que compõem nosso universo estético têm o poder de orientar ética e politicamente nosso comportamento, pois dão referências sobre o que vemos, pensamos e fazemos. A experiência estética permite-nos fazer imagens de nós mesmos e da realidade: faz-nos ver e entender as coisas de maneira concreta.

É uma discussão que norteia o processo de construção do conhecimento em arte, partindo do mundo imagético. As imagens são significativas, pois compõem 
discursos que formam a sensibilidade e a consciência sobre a realidade concreta. Como afirma a autora, a percepção constitui os modos de ver, escutar e tocar o que nos afeta, sensitiva e intelectualmente. As narrativas de imagens podem contribuir na prática educativa em dança, pois elas estabelecem diálogos entre as experiências do educando e as imagens. Podem compor relações com a ação do corpo em cena - ao ver e ser visto -, quando nos permitem criar diálogos, conexões, desdobramentos composicionais com o que expressam sobre nós, configurando uma experiência estética. Essa é, como afirma Pellegrin (2011, p.33), a capacidade de nos relacionarmos com mundo e com os outros sentidos:

\begin{abstract}
Desse modo, a experiência estética no caso de quem dança, se expressa na capacidade de atribuir sentidos aos movimentos, de transformar o gesto em movimento humanamente significado. A experiência estética lida também e necessariamente com o sentimento que é despertado naquele que assiste a alguém que dança. Quando vemos alguém dançar, não percebemos apenas a materialidade do corpo, do gesto, do espaço, dos sons e dos instrumentos musicais, mas também o universo de significações que ali se expressam e que não poderiam ser expressas sem essa materialidade.
\end{abstract}

As imagens podem contribuir para desenvolver a prática artística do professor e de seus alunos, pois a dimensão pedagógica das práticas estéticas interfere em nossa percepção, no corpo e nas formas de entender o que nos acontece.

A partir dessas relações, no decorrer da investigação foram surgindo algumas questões colocadas pelos professores: Qual a relação de alunos e professores com a arte, que ultrapassa as contribuições da escola para a compreensão política e cultural da sociedade contemporânea? Como as imagens podem contribuir para o ensino de dança e como, com elas, nos podemos aproximar do universo simbólico do estudante? Que significado as imagens possuem no fazer artístico em dança? Como as representações das danças, veiculadas pelas imagens, interferem e modificam os significados e o olhar dos estudantes? Como viabilizar uma prática educativa em dança que contribua para o ensino-aprendizado em dança, relacionado às questões?

A investigação busca discutir a repercussão, os impactos e os desdobramentos, ao propor conteúdos específicos do ensino de dança, abordando as relações de corpo em movimento, o modo como se move; com que se identifica; o que o move; como pode ser observado, sentido, dançado, quando se movimenta. Consideramos um mundo imagético composto por diferentes imagens, não 
necessariamente de "corpo" - que poderia remeter, acionar relações com as experiências, as memórias e o universo simbólico -, mas usando a narrativa de imagem, segundo a cultura visual, como mediação entre a concepção de corpo na dança e o universo do estudante.

Essa prática reflexiva instigou-me a pensar sobre o jovem na pedagogia contemporânea. Levou-me a pensar mais detidamente em como o ensino de dança tem sido tratado no espaço da escola em relação à cultura midiática, presente na realidade do jovem, e em como lidar com essas práticas e os saberes cotidianos. A partir da experiência em um grupo de professoras em um curso de formação que ministrei em 2007, hoje decidi dar continuidade à investigação e convidar outro grupo de seis professores de dança da rede pública, visto que surgiram percepções, olhares e dizeres a partir das narrativas das imagens antes não observadas, do processo criativo até o corpo na cena.

Este trabalho de investigação tem como objetivo geral investigar a possibilidade de refletir e sistematizar sobre uma prática educativa em dança, a partir de imagens. Proponho como objetivos específicos: apresentar, a partir do universo visual de imagens do cotidiano, da arte e em modelos estéticos de dança - bailarina, um capoeirista, um passista de frevo, catireiros sapateando, um dançante de jongo, dos orixás, entre outros -, uma proposta educativa para elaboração e sistematização do processo criativo autoral da ação cênica até o corpo em cena; ampliar o repertório e a experiência estética dos jovens, nas mais diversas instâncias artísticas, tendo como referência as imagens; compor, por meio de reflexão, análise e percepção, uma dança autoral e dialógica que produza significados e experiências estéticas; e promover, com uma prática educativa, via imagens, a criação de movimentos capazes de contextualizar, através de jogos corporais, a escuta da dança com as vozes ausentes das vivências no espaço escolar.

Assim, este trabalho está organizado em dois capítulos. No primeiro, "A interface das visualidades e a dança: ver e ser visto", proponho a utilização das imagens como meio de comunicação e diálogo com a cultura escolar e a cultura midiática, possibilitando aos estudantes experienciar, vivenciar e valorizar artefatos e manifestações culturais de grupos e segmentos sociais denominados hegemônicos, e compreender a experiência de ver e ser visto.

O segundo capítulo, "Trilhando caminhos; proposições de uma prática educativa em dança", efetiva a proposição de uma prática educativa que surgiu das 
inquietações sobre a realidade do ensino da dança vividas por um grupo de professores com dificuldades de mediar uma prática significativa. Propõe uma investigação com professores colaboradores, embasada na pesquisa-ação. $\mathrm{Na}$ primeira seção desse capítulo, sobre o processo criativo em dança para a ação cênica, foi elaborado um gráfico que estabelece interfaces entre as experiências individuais dos participantes da investigação e o processo criativo em dança proposto. A segunda seção, "Reflexões sobre o processo criativo em dança", descreve como o processo acontece em sala de aula, desde sua elaboração até levar o corpo para cena. A terceira seção, "Elaboração das matrizes de movimento e o corpo em cena", traz a descrição do processo de construção das matrizes de movimento de cada dançante, a partir de narrativas imagéticas, até levar o corpo para cena, na produção das "Poéticas do corpo em cena". A quarta e última seção, "Poéticas do corpo em cena", descreve, passo a passo, o processo criativo das cenas produzidas para levar o corpo para cena. 


\section{TRILHANDO CAMINHOS: PROPOSIÇÕES DE D A N Ç A}

A escola é um dos espaços em que se produzem significados sobre 0 quotidiano, por meio de práticas culturais, conceitos e valores. Como espaço pedagógico e cultural, a instituição escolar fez-se o abrigo desta investigação, que objetiva compreender melhor o ensino de dança e suas proposições dentro da realidade da educação pública, com as suas implicações políticas e culturais. Conforme já relatamos aqui, foi a partir das inquietações de um grupo de professores sobre a realidade do ensino de dança, com dificuldades de mediar uma prática educativa significativa, que optamos por este objeto de estudo. Para trilhar caminhos, tomamos como referência a experiência visual e o contexto educacional, como considera Martins (2011b, p.31):

\footnotetext{
Não podemos negar e muito menos ignorar $o$ fato de que na contemporaneidade, objetos e imagens são trabalhados como eixos convergentes de narrativas "espetacularizadas" e "ressignificadas" que propõem e discutem conflitos políticos e morais, problemas econômicos e sociais, dilemas éticos e práticas de ensino/pesquisa que acabam por fazer narrativas imagéticas um recurso importante para pensar, refletir e educar.
}

As imagens, segundo a cultura visual, trazem recursos e operam de diferentes óticas, mediando a quebra de paradigmas entre baixa e alta cultura, trazendo para a discussão as diferentes interpretações e os significados dos objetos e das imagens artísticas que podem mudar a partir dos modos de ver e ser visto. É possível romper, assim, com categorias formais e institucionalizadas como a dicotomia entre arte popular e arte erudita, imagens de arte e imagens publicitárias.

A partir dessas referências, optamos por trilhar caminhos metodológicos para efetivar a proposição da prática educativa embasados, na pesquisa-ação, por compreendê-lo, a partir de seus objetivos reflexivos como construção do conhecimento, permitindo um ambiente privilegiado para a interação, a sensibilidade e a reflexão sobre o processo de construção de conhecimento. A pesquisa-ação é caracterizada por Thiollent (2004, p. 14), como:

Tipo de pesquisa social com base empírica que é concebida e realizada em estreita associação com uma ação ou com a resolução de um problema coletivo e no qual os pesquisadores e os participantes representativos da situação ou problema estão envolvidos de modo cooperativo ou participativo. 
Ela não é apenas uma orientação emancipatória ou mediadora de resolução para as problemáticas de grupos das classes dominantes. No ambiente da educação, ela pode mediar uma tomada de consciência da realidade observada - ou na qual que se esteja inserido - que necessita de uma intervenção transformadora. Thiollent (2004) assegura que, por meio de pesquisas orientadas pelas concepções teórico-práticas da pesquisa-ação, é possível entender a não neutralidade das ações das escolhas e estudar as dinâmicas dos problemas, das ações, das decisões, das negociações, dos conflitos. Merece, ainda, especial atenção, a possibilidade de tomadas de consciência entre os sujeitos durante o processo de transformação da situação.

A partir dessas considerações, na busca de uma prática educativa para o ensino de dança, propomos promover um trabalho com a dimensão da realidade entre os sujeitos, criar possibilidades de uma prática libertadora não reprodutora de relações de dominação e alienação na escola, mas, sim, um trabalho de intervenção e diálogo na relação do corpo que dança. Fundamentada em relações poéticas que permitam maior conscientização do corpo dançante, a partir de expressões cênicas, na busca por uma ação pedagógica crítico-reflexiva, focada na intervenção das realidades dos participantes, partimos do individual para o coletivo. Essa ação conduz a visões e percepções acerca das singularidades, dos diálogos corporais, das conexões rizomáticas, dos diálogos composicionais e dos desdobramentos composicionais por meio da criação e da recriação de ações do corpo em cena.

A imagem mediadora do processo ensino-aprendizagem, na organização do trabalho pedagógico voltado para essa prática reflexiva no processo criativo de uma ação cênica, possibilita pensar no ser social com sua identidade e cultura, sujeito de sua própria história e de suas relações. Como afirma Freire (1996, p.41):

\footnotetext{
Uma das tarefas mais importantes da prática educativo-crítica é propiciar as condições em que os educandos em suas relações uns com os outros, e todos com o professor ou a professora ensaiam a experiência profunda de assumir-se. Assumir-se como ser social e histórico, como ser pensante, comunicante, transformador, criador, realizador de sonhos, capaz de ter raiva porque capaz de amar. Assumir-se como sujeito porque capaz de reconhecer-se como objeto.
}

Esta é uma proposta de valorização da identidade cultural de que fazemos parte. A valorização de experiências e narrativas é fundamental, pois ao mesmo tempo, oportuniza condições aprendizagem de um conjunto de conhecimentos que possibilitem uma leitura da realidade contextualizada e apresenta a dança como 
linguagem específica, desenvolve uma criação lúdica, uma dança possível, não excludente e fundamentada culturalmente. As questões sobre o corpo podem tender para a humanização ou a alienação, dependendo da proposta educativa que é levada para a escola. Existe uma dicotomia no pensamento pedagógico que ora considera a cultura cotidiana, discriminando-a, ora investe no cultural, ignorando a sistematização dos elementos simbólicos.

A cultura visual permite compreender melhor os processos ideológicos que vêm sendo reforçados nos discursos sociais, políticos e econômicos do modo de produção vigente; quanto mais o jovem estiver exposto às mensagens da mídia e da cultura visual, maior será a probabilidade de que adote atitudes e crenças veiculadas nessas mensagens (GERBNER, 2006 apud HERNANDEZ, 2007). Com esse entendimento, buscamos aproximar-nos das poéticas visuais, promovendo diálogos com o ensino de dança e com as visualidades. Conforme Martins (2011b, p. 21):

A cultura visual não estuda apenas um setor, uma parcela ou recorte desse
mundo simbólico denominado "arte", mas se preocupa com as
possibilidades de percepção que se irradiam através das imagens de arte,
de informação, de publicidade e de ficção transpassando o mundo em
muitas direções. Deslocando-se através do espaço, como artefatos prenhes
de sentidos e significados, objetos e imagens de arte se oferecem para
conexões rizomáticas potencialmente abertas para uma diversidade de
interpretações e aprendizagem.

Nessa direção, as imagens foram utilizadas com o intuito de intensificar os sentidos e os significados estéticos que elas oferecem para o corpo que dança abertos a várias interpretações e recriações. Uma das principais preocupações foi tornar possível, por via da compreensão crítica de imagens, a composição de uma matriz em dança, de modo a provocar a investigação artística, numa concepção dialógica do movimento humano e, por conseguinte, fazer do corpo, seu agente para a elaboração do processo criativo da composição de movimentos em uma ação cênica. Martins (2011b, p.27):

Para desenvolver uma compreensão crítica de objetos e imagens de arte, é necessário considerar que 0 mundo simbólico e suas formas são construções sociais mediadas por contradições que ocupam [...] espaços instáveis e contraditórios, abertos a novas intepretações e aprendizagens.

São espaços possíveis, em que podemos oportunizar aos estudantes a experimentação e a pesquisa para construção de relações com ideias, visualidades e práticas que, com seu mundo simbólico, façam parte do repertório artístico e imagético contemporâneo. 


\subsection{Processo Criativo em Dança para a Ação Cênica}

Para relacionar as interconexões teóricas e metodológicas do processo investigativo, elaboramos um gráfico que estabelece interfaces entre as experiências individuais dos participantes e o processo criativo proposto, conforme Figura 1.

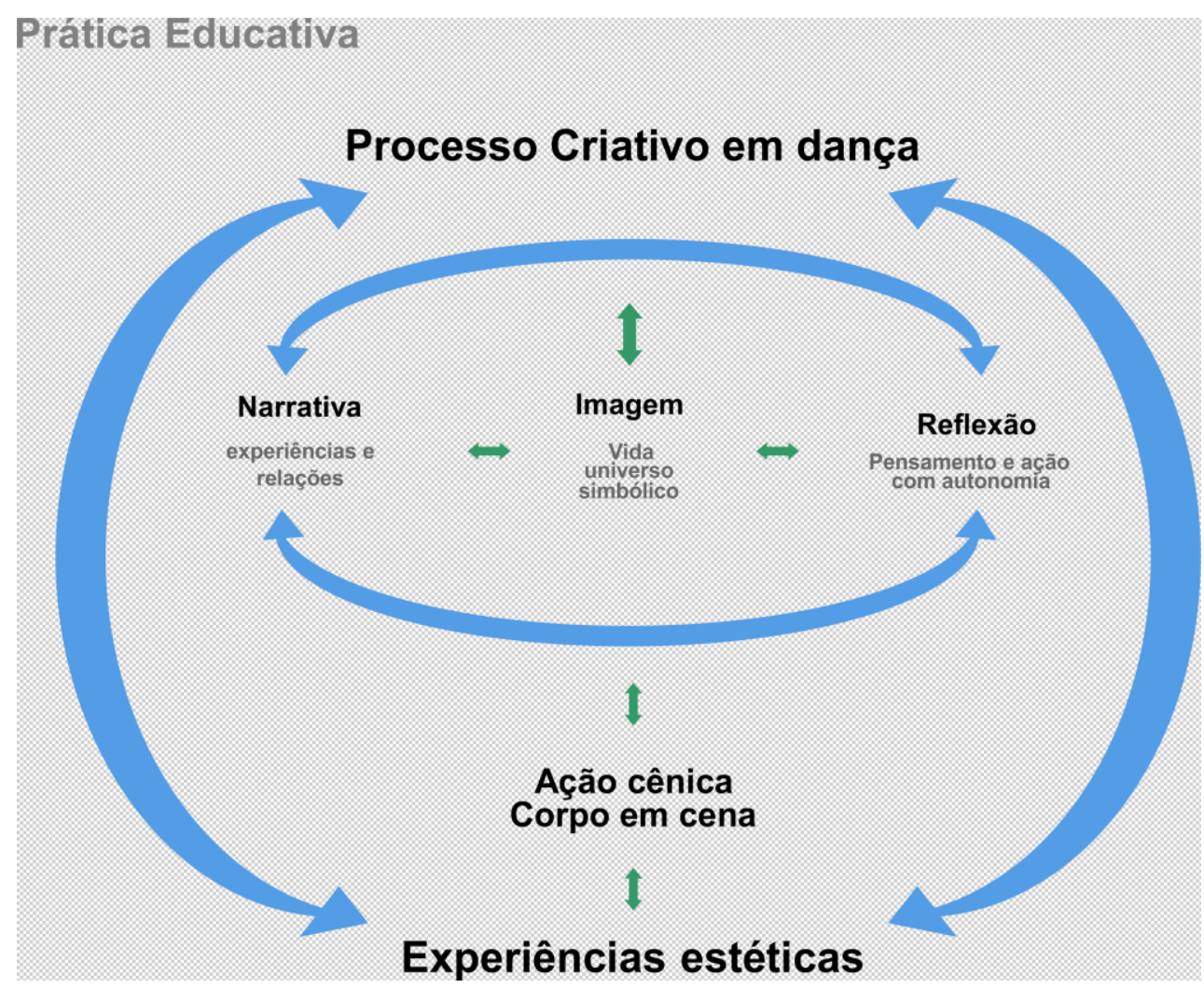

Figura 1 - Gráfico do Processo Criativo em Dança Fonte: Lana Costa Faria

A prática investigativa se formou por meio de um grupo de 6 professoras de dança da rede estadual de ensino da cidade de Goiânia, com encontros que ocorreram semanalmente por um período de 3 horas. Para convidar as professoras utilizamos, como critérios, estar atuando em sala de aula por mais de 5 anos, ser professor/artista e ter disponibilidade de horário. Os encontros se iniciaram em 2015, na segunda quinzena de maio até junho, perfazendo o total de 7 reuniões. Depois das férias coletivas de julho, retornamos em agosto e, até novembro, realizamos 17 encontros. Em 2016, nos meses de fevereiro e março, houve 6 encontros. Iniciamos a investigação com 6 professoras, porém, no segundo semestre de 2015, a professora Leticia deixou o grupo, devido a mudança de horário na escola e a outros projetos pessoais. 
Foram colaboradoras da investigação: Ana Paula Mello Blotta, Alice Batista Assis, Cláudia Cardoso Barreto, Mônia Cristina G. A. Santana e Itana Parreira Fleury, todas professoras concursadas em dança, em exercício há mais de cinco anos na rede estadual de educação, onde atuam dançando, e algumas delas também dançam fazendo parte de grupos de pesquisa e produção. O percurso de cada uma delas pode assim ser descrito:

Professora Ana Paula Blotta Melo: fez dança desde sua adolescência, no SESC/ São Carlos, participando de grupos de dança e frequentando vários cursos oferecidos, como jazz, ballet contemporâneo, dança afro, danças populares brasileiras, entre outras. Sua formação inclui Licenciatura em Educação Física, com especialização em Educação Física Escolar, na Universidade Federal de Goiás (UFG). É concursada como professora de dança na rede estadual de Educação de Goiânia. Trabalha com dança em uma escola de inclusão do Fundamental dessa mesma rede há mais de oito anos.

Professora Alice Batista Assis: sua primeira experiência com dança foi com jazz e ballet aos 18 anos, tendo iniciado seus estudos teóricos em dança no curso de Licenciatura em Educação Física. É concursada como professora de dança na rede estadual de Educação de Goiânia. Trabalha com dança no ensino fundamental e médio, há mais de seis anos na rede. Atualmente continua fazendo cursos de formação em dança.

Cláudia Cardoso Barreto: tem formação em Licenciatura em Educação Física, com experiência em dança em várias escolas e em projetos como os da Escola de Dança e Integração Social para Crianças e Adolescentes (EDISCA) em Fortaleza. Posteriormente, em Goiânia, frequentou cursos de formação em dança de vários estilos. Concursada em dança pela rede de Educação do estado, fez especialização em Pedagogias da dança, definindo sua área de atuação. Trabalhou em escolas de tempo integral e várias escolas do ensino formal na rede estadual de Educação de Goiânia. Hoje participa do grupo de Pesquisa Artística Núcleo Coletivo 22, da UFG, com a arte popular e a dança contemporânea e trabalha com formação de professores no Centro de Estudo e Pesquisa Ciranda da Arte. Atua há mais de cinco anos na rede.

Professora Mônia Cristina G. A. Santana: iniciou seus estudos em dança aos 6 anos de idade na cidade de Anápolis - Go. Aos 15 anos, ministrou aulas de dança para escolas particulares de Anápolis. Aos 16 anos, participou do grupo Spazzio. Mudou-se para Goiânia, onde frequentou vários cursos de dança, como: jazz, sapateado, ballet, dança moderna, dança contemporânea e Danças Populares Brasileiras. Cursou 
Licenciatura em Educação Física, foi professora de dança no primeiro Projeto de Atividades Educacionais Complementares (PRAEC) na rede estadual de Educação de Goiânia em 1998. É concursada em dança pela rede estadual de Educação de Goiás há mais de oito anos. Participou do grupo "Ciranda de Fogo", com pesquisa em Dança Popular tradicional, e atualmente compõe o Grupo de produção "Grupo Experimental de Dança" ambos do Centro de Estudo e Pesquisa "Ciranda da Arte".

Professora Itana Parreira Fleury: iniciou seus estudos aos 6 anos em uma escola de artes, estudou piano e ballet clássico em Santos, no estado de São Paulo. Depois, nos anos 70, dança moderna e contemporânea em Niterói. Mudou-se para Goiás nos anos 80, estudou ballet, jazz e sapateado. Iniciou sua carreira docente ministrando aulas de dança nas academias. Mudou-se para Porangatu, onde administrou uma academia de dança por 10 anos. Em 98 retornou a Goiânia, trabalhou na escola de arte Veiga Valle. Depois atuou no Centro Livre de Artes e na secretaria da Cultura Municipal, onde permanece até os dias de hoje. Atualmente trabalha também com ensino de dança - ensino especial - na rede estadual de Educação de Goiânia. Participou de um grupo de produção - Araticum - como intérprete criadora. Atua com ensino de dança na rede do ensino estadual há 24 anos.

Todo o processo aqui revelado foi registrado em fotos, filmado pelas cinco professoras, e relatos foram inseridos no diário de bordo em forma de narrativas individuais sobre as impressões obtidas por elas (Figuras 2, 3 e 4, a seguir). A professora colaboradora Cláudia Barreto assim revelou: "Registrar ou melhor fotografar as colegas em movimento, foi como jogar uma lente de aumento sobre partes do corpo, trajetória ou mesmo dinâmica dos movimentos realizados. Quantas possibilidades para danças..." (Figura 2).

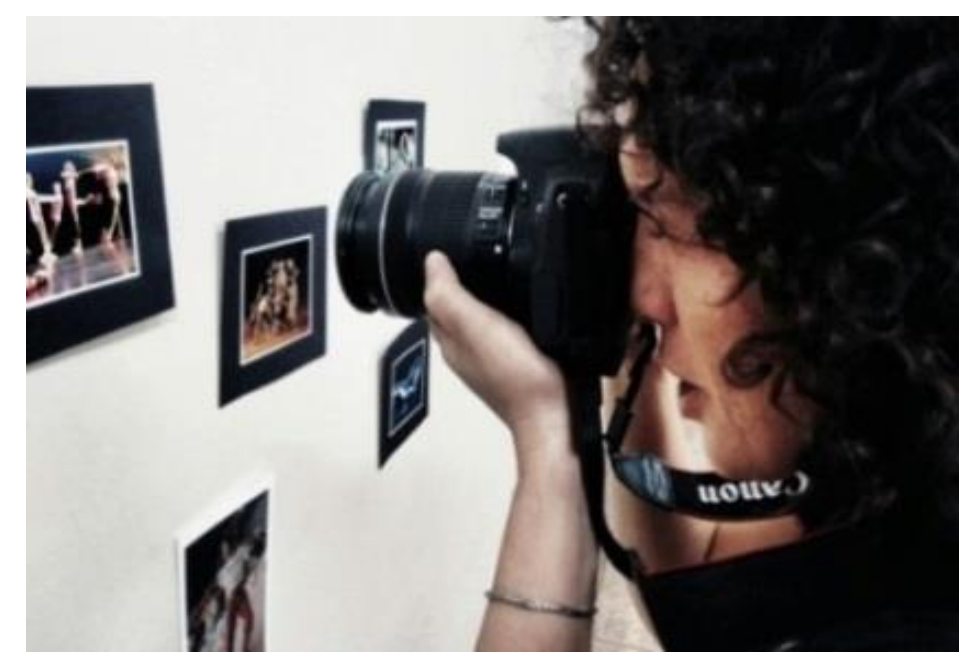

Figura 2: Registro das aulas (1)

Fonte: Integrantes do grupo 


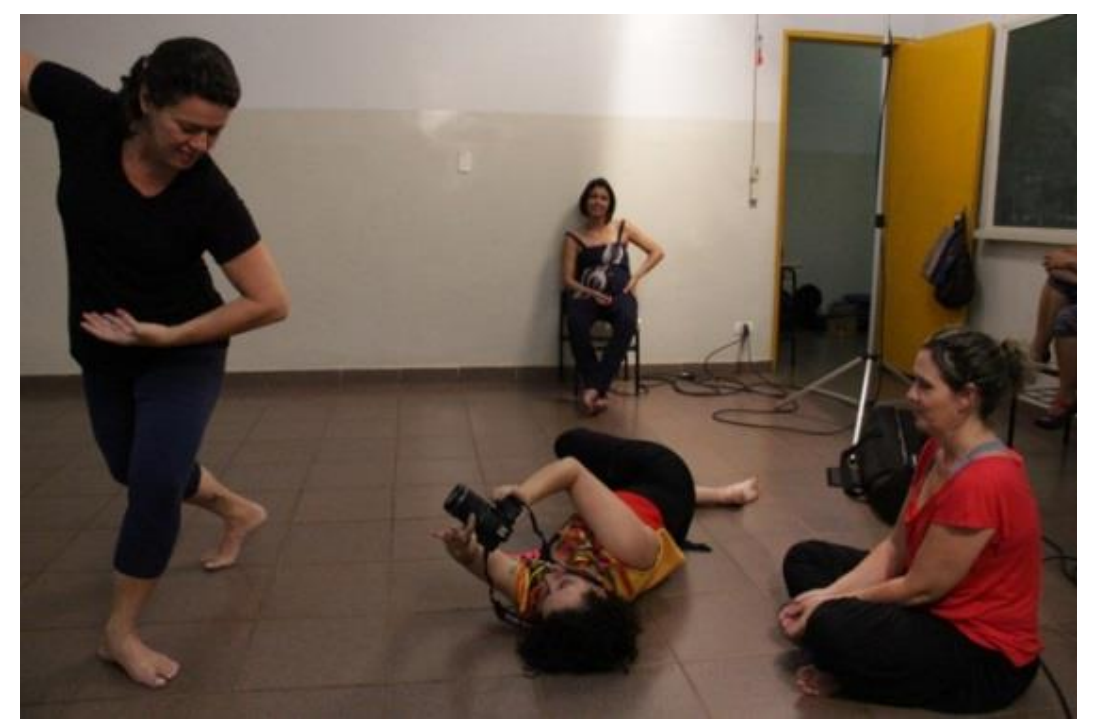

Figura 3: Registro das aulas (2)

Fonte: Integrantes do grupo

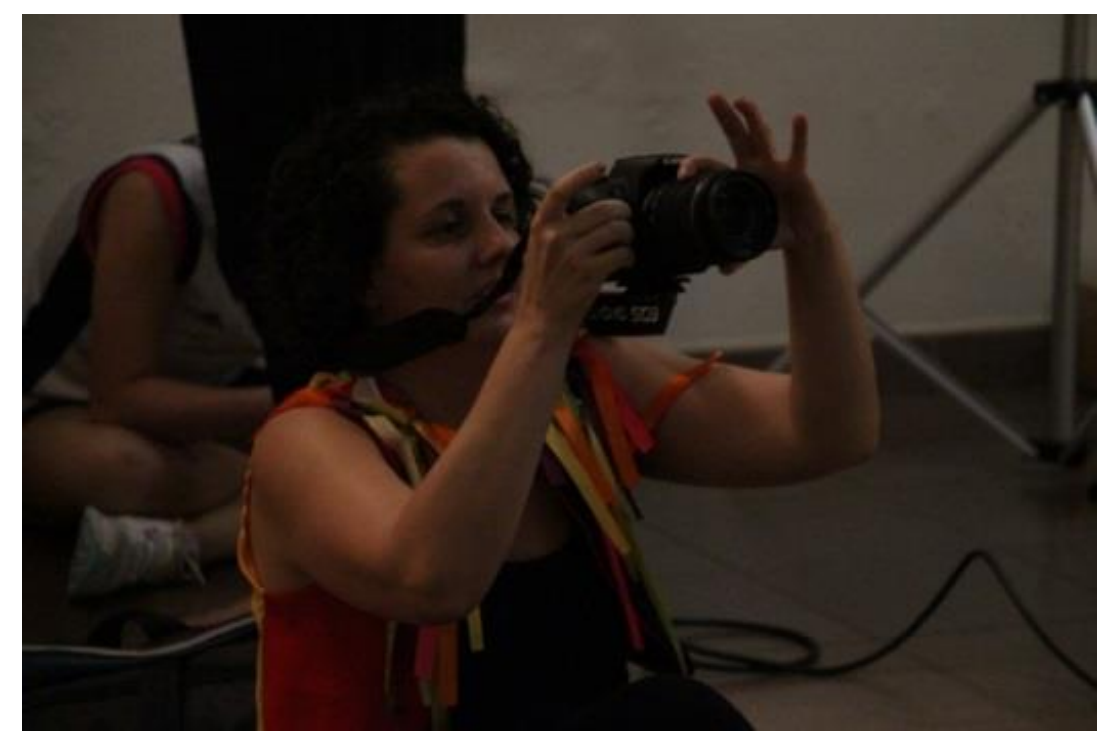

Figura 4 : Registro das aulas (3) Fonte: Integrantes do grupo

O diário de bordo foi utilizado como registro de nossos encontros e reuniões, em que os impasses e as reflexões construíram narrativas de nossas práticas, dados esses utilizados na investigação para que possamos evidenciar a aprendizagem como processo, em íntima relação com o que cada uma percebeu e sentiu durante o processo de criação em dança. A construção se deu coletivamente, cada uma no seu tempo e ritmo individual, contribuindo com a outra, respeitando os limites e as diferenças. Ao longo do processo de criação em dança, conversas e mais conversas teceram um caminho unitário, formado de nuances singulares. Ao 
elaborarem a narrativa de seus processos individuais de criação, as colaboradoras se tornaram autoras do acontecimento, pois vivenciaram-no de maneiras diferentes, porém, compondo um desenho único (Figura 5).
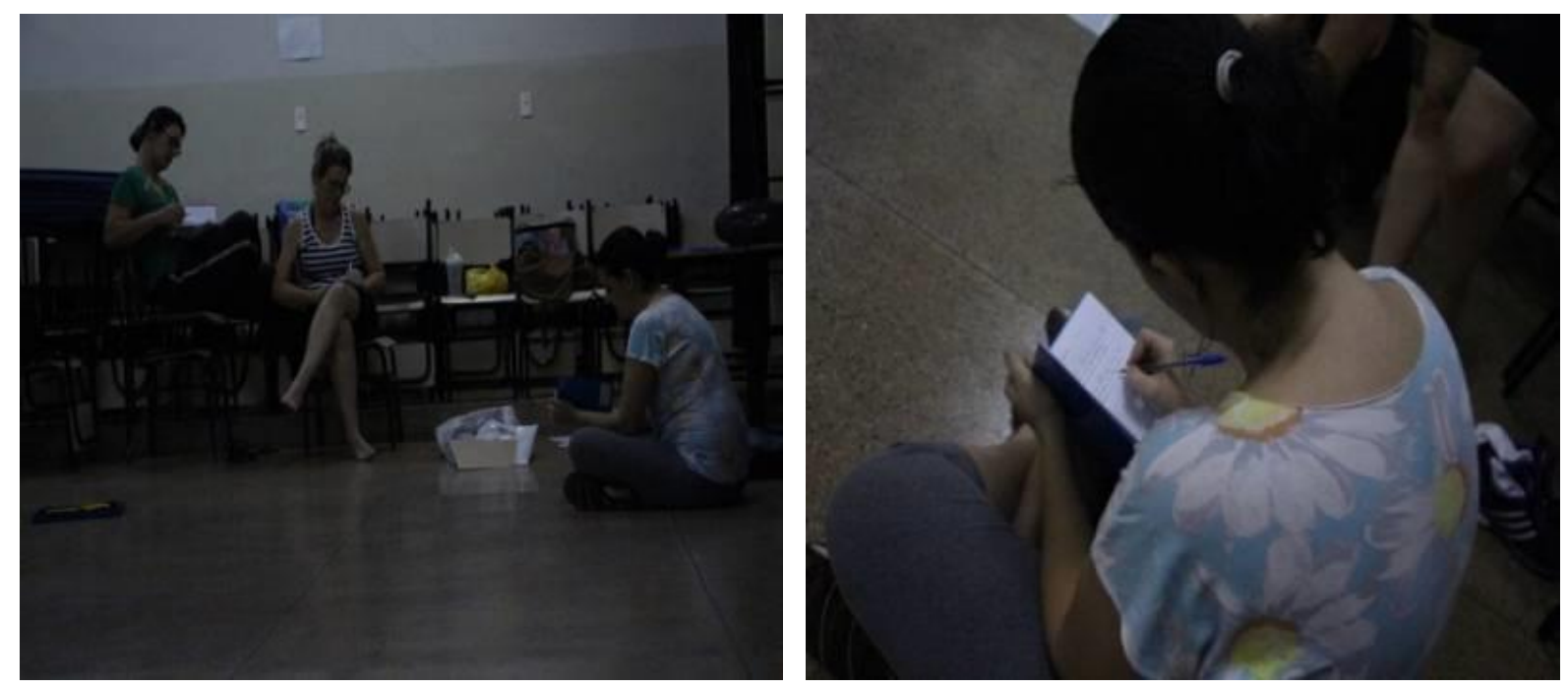

Figura 5: Registro das aulas (4)

Fonte: Integrantes do grupo

\subsection{Reflexões do Processo Criativo}

A prática investigativa do processo criativo em dança se deu por meio do grupo das cinco professoras de dança, a partir de vivências para ação cênica. Desenvolvemos uma proposta elaborada com base nos elementos estruturais do movimento não apenas de suas formas externas, mas também das dimensões mental e emocional, segundo estudos da Coreologia, princípios de Rudolf Laban. Laban foi um dos inovadores e revolucionários do pensamento humano de sua época. Segundo Arruda (1988, p.6):

Laban conseguindo sintetizar a linguagem do movimento, contribuiu para uma nova visão, de expressão do corpo que também pressiona, talha, soca, sacode, pontua, desliza. Percebeu a alienação causada pelo movimento mecânico e apontou um caminho liberador através da consciência do corpo e do movimento natural. Mostrou que os gestos padronizados induzidos pelas ações das máquinas por exemplo, ou impostos pelos papéis sociais terminaram por dessensibilizar 0 homem, restringindo sua potencialidade expressiva, submetendo-o a uma rotina de gestos seriados, mesquinhos e pobres.

A partir desse pressuposto, procuramos levar o corpo para cena, concebendo não uma dança regida por uma lógica cartesiana, mas como uma proposta aberta às 
múltiplas experiências sensíveis das protagonistas. A dança fundamentada na linguagem do movimento, partindo das estruturas coreológicas. Propusemos, por meio delas e nas conexões entre elas, o emprego dos repertórios pessoais na elaboração de composições criadas durante o processo individual e coletivo. Composições essas que partiram de movimentos estruturados como Lobo e Navas (2008, p.40) sustentam:

Estrutura do movimento é aquela realizada pelo corpo cênico organizandose em um contexto. Assim como as palavras são organizadas para dar significado ao texto - frases, parágrafos e capítulos - e as linhas, volumes e cores organizados para compor a pintura, os movimentos também são organizados para estruturarem os conteúdos e imagens de uma dança.

Para abordar a dança como linguagem do movimento, é necessária a organização em estruturas. A nossa proposta utilizou como estruturação a Estrela Labaniana da dança, elaborada por Laban e Preston, que se subdivide nas seguintes dimensões: partes do corpo, ações, espaço, dinâmicas e relacionamentos (MARQUES, 1992, p. 07) (Figura 6).

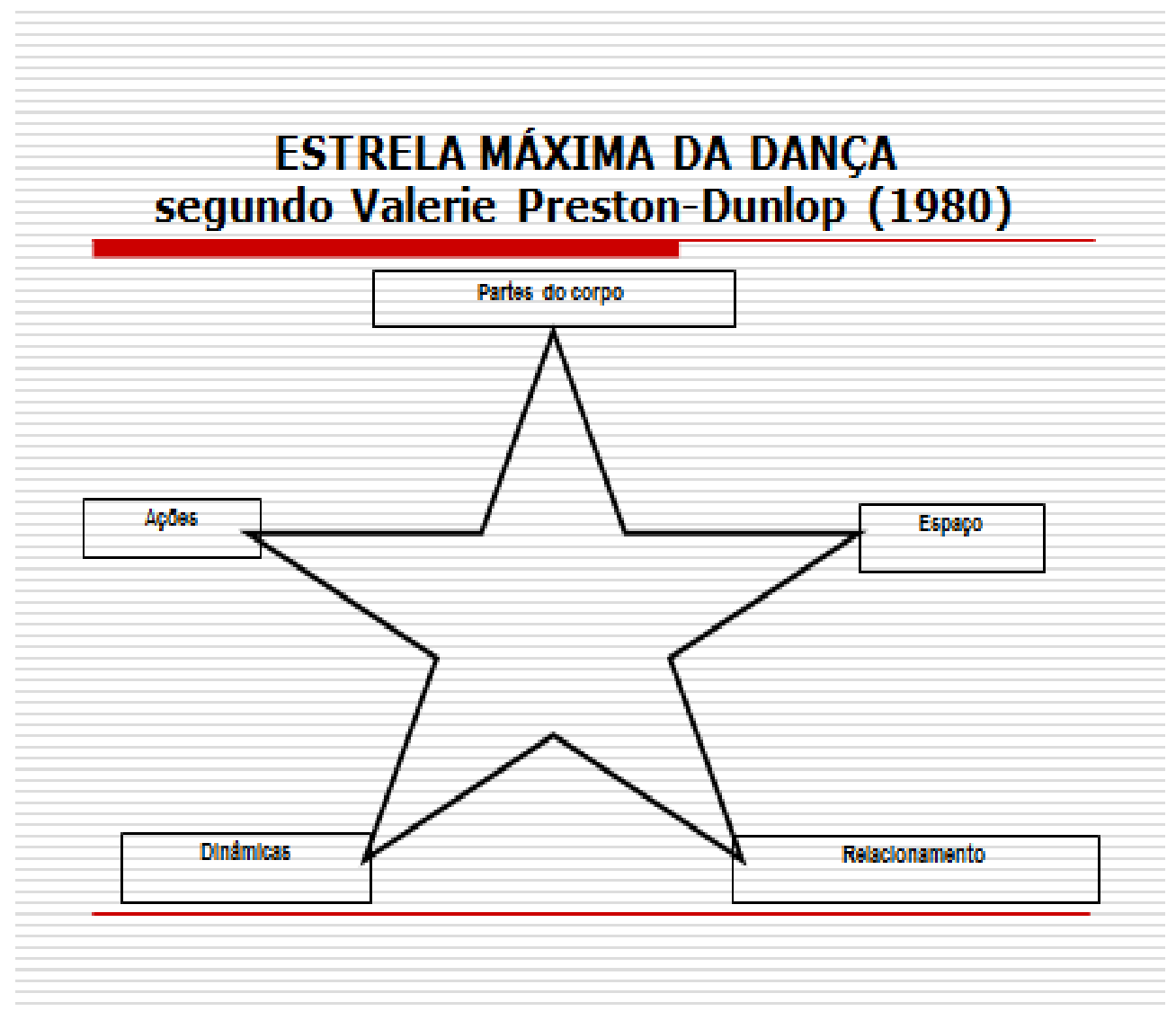

Figura 6: Movimento - Estrela máxima da dança Fonte: Valerie Preston - Dunlop (1980) 
Tomemos os elementos das estruturas dos movimentos como partes do corpo: por dentro - consciência corporal (Alexander, Ivaldo Bertazzo etc.) e por fora - estudo da Coreologia, ou seja, aquilo que se pode ver, observar em um movimento a ser compartilhado como articulações; tronco; membros; cabeça; e superfícies. Ações básicas estão presentes nas danças a serem criadas, como golpear, sacudir, socar, torcer, flutuar, chicotear etc. As dinâmicas: peso (leve, firme); tempo (prolongado, repentino, acelerado); espaço (direto, flexível); e fluência (livre, controlado). O espaço (Kinesfera): níveis (alto, médio, baixo); plano (porta, mesa, roda); tensões; progressões; projeções. Essa é a base utilizada na elaboração dos movimentos corporais das matrizes das narrativas visuais.

A elaboração dos processos criativos do movimento estruturado vivenciado ocorreu a partir da improvisação, da composição de movimentos e repertórios. As professoras tornaram-se integradas com seu próprio corpo e desenvolveram vocabulário de movimentos, criando, assim, um repertório próprio, ampliando e afirmando a personalidade, revelando suas preferências.

$O$ processo de criação teve início ao ser apresentado às professoras colaboradoras um universo de visualização imagética (Figura 7) de várias fontes (Anexo 1), como fotografias cotidianas, recortes de revistas, jornais, catálogos, calendários, folders e modelos estéticos de danças, como uma bailarina; um capoeirista; um passista de frevo; um catireiro sapateando; um dançante de jongo, de lundu, de Maracatu, de congada, de ciranda, um orixá, entre outros, distribuídos pelo espaço.
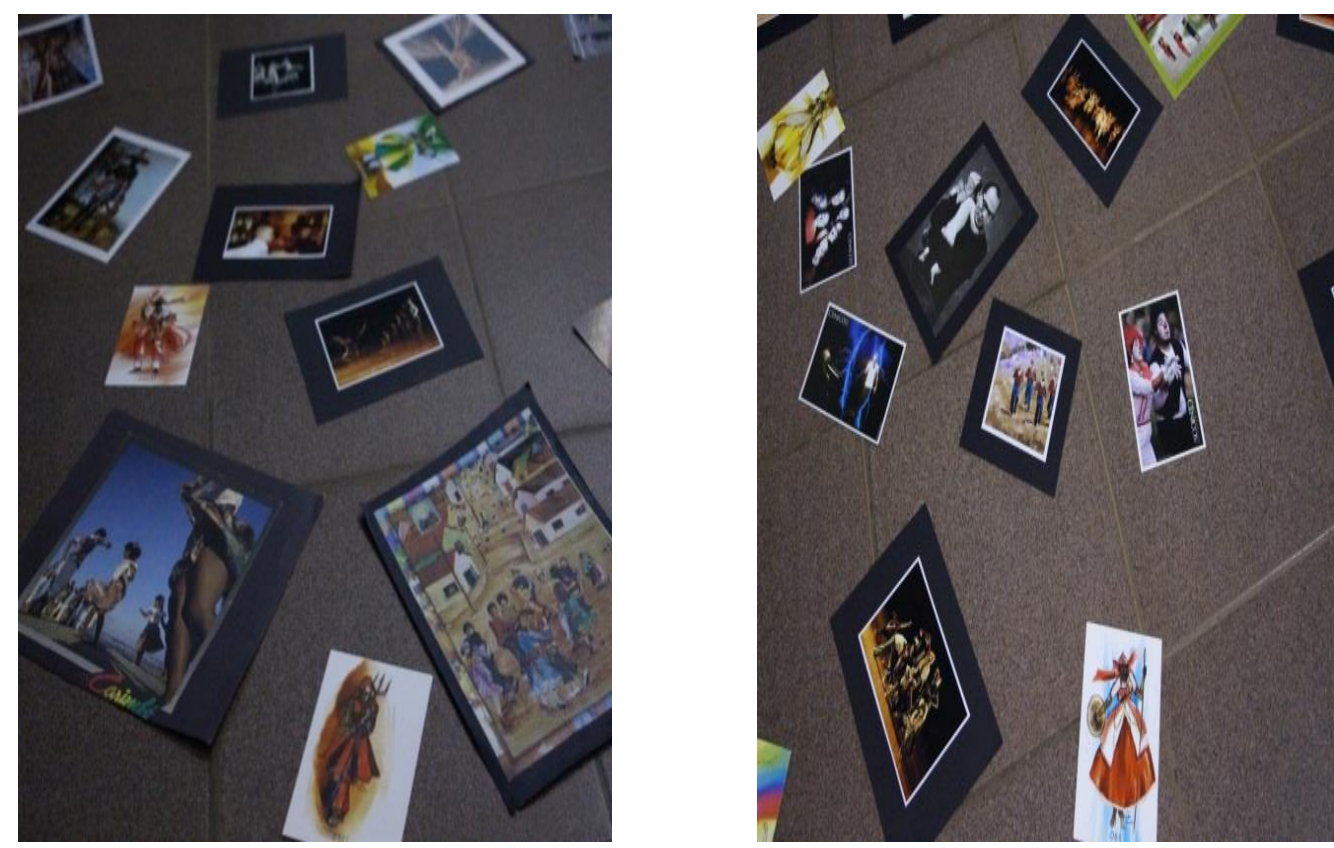

Figura 7: Registro do universo imagético Fonte: visualidades imagéticas de várias fontes 
Em seguida foi proposto que as alunas selecionassem algumas imagens segundo seu gosto pessoal, com as quais se identificassem (Figura 8), a partir das seguintes provocações: como me vejo na imagem; o que elas me permitem pensar; que relação pode ser estabelecida entre elas e o que eu vivo, penso, sou; quais imagens têm sentido e significado para minha vida; quais das imagens me representam; falam sobre mim; a partir de minhas experiências, quais das imagens reverberam em minhas memórias.

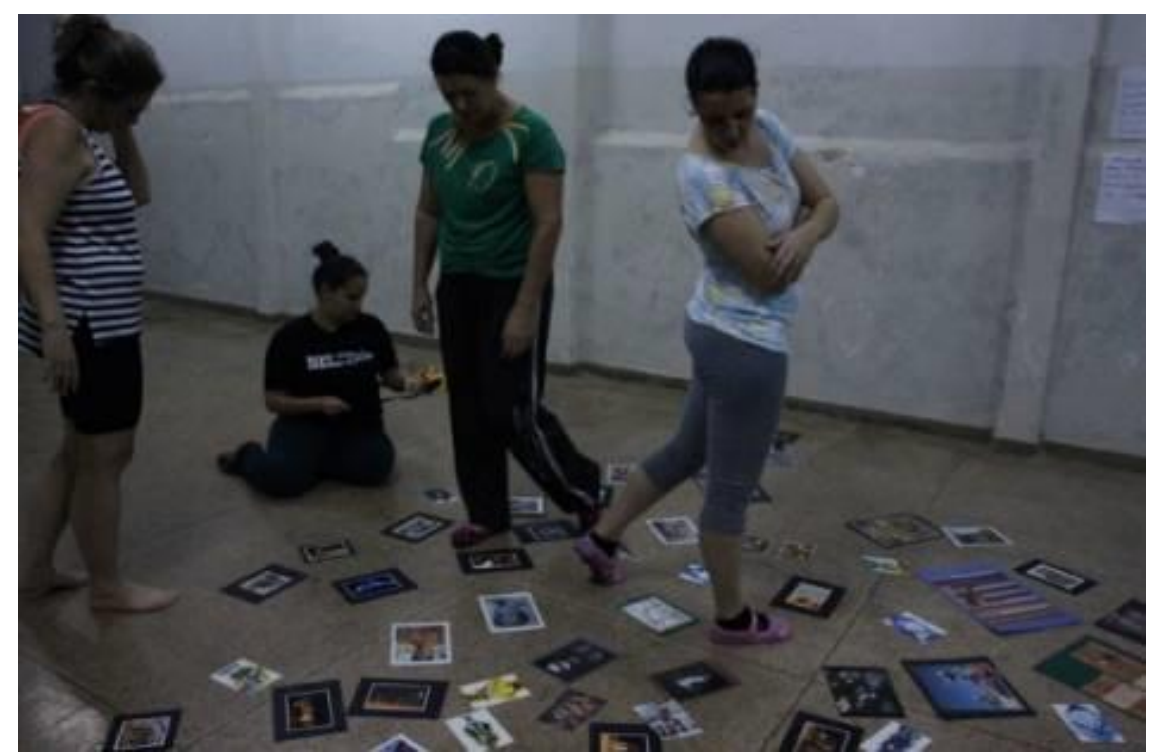

Figura 8: Escolha das imagens (1) Fonte: Integrantes do grupo

A partir dessas escolhas (Figura 9), apresentamos os seguintes questionamentos: comente sobre suas escolhas: por que a escolha? Onde me vejo na imagem? Como me vejo? Como me reconheço nas imagens? Cada dançante poderia indicar quantas imagens Ihe conviessem, segundo seu interesse. Argumenta Tourinho $(2011$, p.10) que:

compreender a experiência de ver e ser visto, não significa, apenas, restringir-se a um olhar, a uma visão ou uma perspectiva. Significa "o ver e ser visto" compreendido também em suas parcialidades, ou seja, no aspecto fragmentado que essas experiências oferecem quando nos damos conta dos significados que atribuímos às imagens. Significados que se constroem não apenas em consequência das limitações, cegueiras, vieses e circunstâncias que nos constituem e formam os modos, ângulos e contextualidades das experiências visuais, mas, também, significados construídos em consequência das diferenças e diversas maneiras como as imagens podem ser (re)construídas, transfiguradas, postas em circulação e "recepcionadas". 

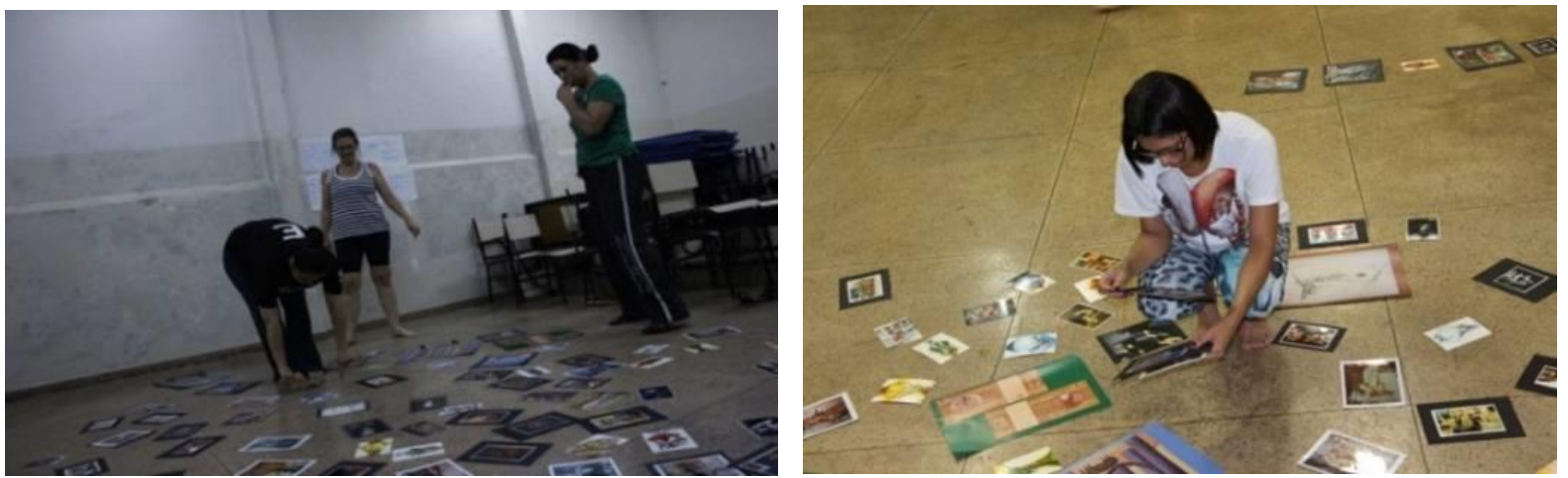

Figura 9: Escolha das imagens (2) Fonte: Integrantes do grupo.

Partindo dessa relação, as escolhas foram relacionadas à realidade vivida pelas alunas no universo onde cada uma, com suas escolhas e diferenças, faz opção por trilhar caminhos. São escolhas que falam de si, sobre si; em que se veem, se expressam ou se reconhecem em suas narrativas visuais sobre a vida, 0 cotidiano, as memórias e a subjetividade.

Iniciamos assim o processo criativo para levar o corpo para cena, como revela o relato da professora Mônia (Figura10):

um dos primeiros estudos foram apresentação de um gráfico criativo em dança onde foram feitos cartazes nos encontros a serem trabalhados. Primeiramente a escolha das imagens que estavam espalhadas na sala onde escolhi seis imagens que mais chamaram minha atenção, de acordo com eu estava vivendo nesses últimos três anos, tanto no trabalho com dança como nas minhas experiências vividas até o momento. (Diário de bordo, 2015)

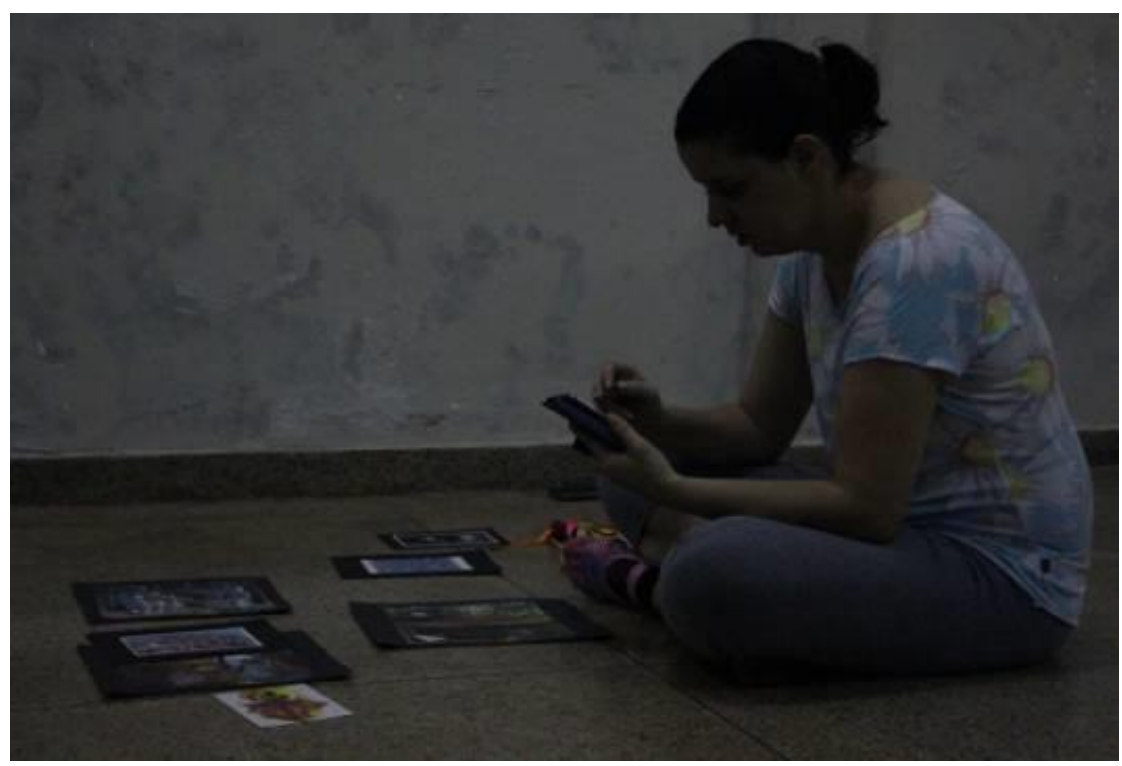

Figura 10: Escolha das imagens (3) Fonte: Integrantes do grupo. 

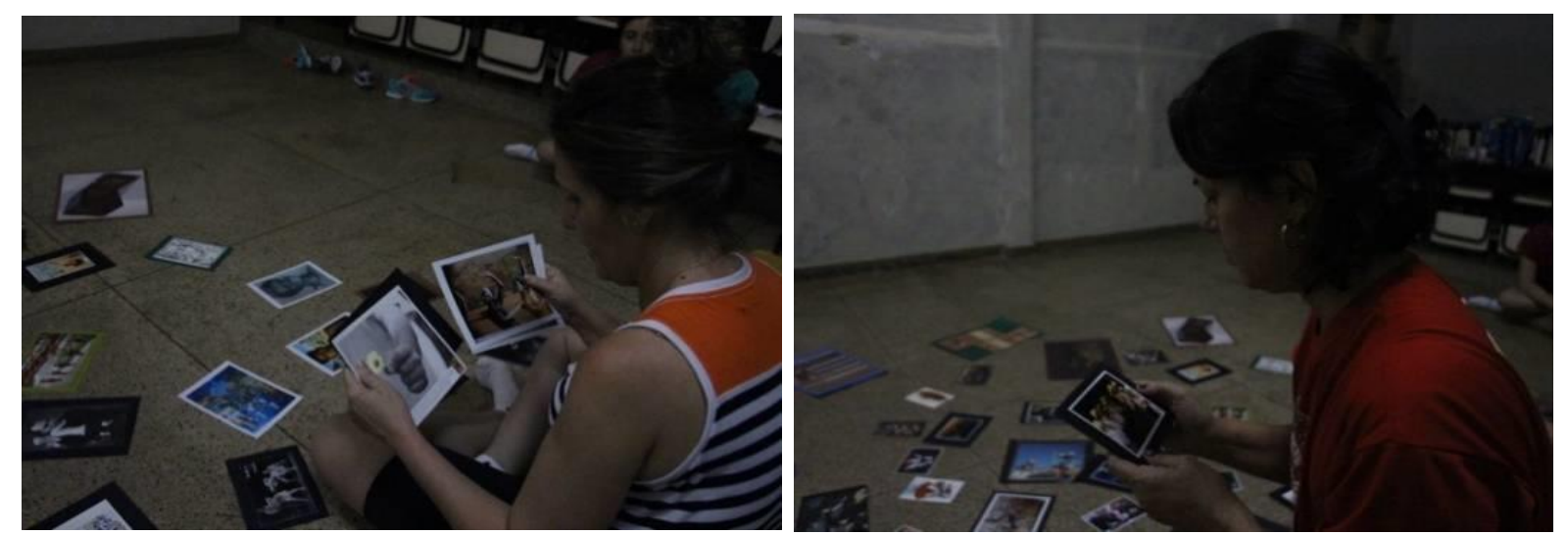

Figura 11: Escolha das imagens (4)

Fonte: Integrantes do grupo

A professora colaboradora Ana Paula (Figura 11) também fez suas considerações sobre as escolhas das imagens:

o trabalho com as imagens me remete sempre a um diálogo com a memória numa relação dialética de ação reflexão. As imagens que eu escolhi têm relação com a minha individualidade, gostos, desejos, saudade, tempo e também com a história de dança que tenho escrita no meu ser. Elas me levaram a um universo de relação com a construção da minha história com a dança. Fiz escolhas de imagens pontuais, como se fosse um percurso histórico da dança na minha vida até que ela viesse a se tornar fruto do meu trabalho. (Diário de bordo, 2015).

A professora colaboradora Alice afirma: "Algumas imagens foram escolhidas devido a minha história na dança e meu processo/percurso de trabalho" (Diário de bordo, 2015).

Depois das escolhas, foi proposta a construção da narrativa oral com base nas questões provocativas, a partir das imagens escolhidas, com a intenção de relacionar os sentidos e significados para aproximação da subjetividade de cada participante - um espaço de reflexão de si.

As narrativas de suas práticas vêm auxiliar a reflexão sobre a ação, são uma oportunidade de apropriação do fazer, como também de processamento da identidade da consciência de si. Larrosa (1994, p.33-34), ao estudar a constituição do sujeito, destaca que,

ao narrar-se, a pessoa diz o que conserva do que viu de si próprio, percebe sua permanência no tempo, presta conta a si mesmo, numa ação valorativa. A narrativa também nos permite algo que a interpretação não alcança. $A$ narrativa como articulação de ações no mostrar o movimento de criar condições favoráveis à reflexão sistemática sobre as práticas 0 desenvolvimento da capacidade de estar a sós, da sensibilidade estética. 
As narrativas das imagens possibilitam acionar as experiências e as relações com a vida, que cada uma atribui à sua cultura, à sua identidade e à sua memória.

Ao elaborar sua narrativa, as participantes são provocadas a pensar em que medida as relações com as imagens da cultura visual produzem olhares sobre 0 mundo, sobre nós próprios, sobre os outros; e a considerar como, no espaço educacional, essas questões podem ser problematizadas e contempladas em um trabalho de investigação. Como afirma Martins (2011b, p. 22):

\begin{abstract}
A interpretação de objetos e imagens é uma prática que mobiliza a memória visual e reúne sentidos da memória social construída pelos indivíduos professores e alunos que interpretam. Nesse processo de interpretação ao tentar compreender o sentido simbólico das imagens, indivíduos são influenciados pelo imaginário dos lugares sociais por onde passam, vivem ou habitam. O território visual onde as pessoas estão situadas - moram, frequentam etc. -, ou seja, o contexto das esferas das suas relações com o mundo as coloca num processo de construção de sentidos e significados, de práticas de interpretação.
\end{abstract}

A escolha de imagens promove relações com a história de vida de cada dançante no momento presente ou com memórias corporais únicas e singulares, ganhando sentido e significados no encontro com o mundo da dança e no seu percurso no ensino das práticas de interpretação. Como relata a professora Ana Paula em sua narrativa, entremeada pelas imagens - Figuras 12,13, 14, 15, e 16 escolhidas:

As escolhas das imagens têm a ver com a minha identidade e com a relação corporal que eu tenho com a dança na minha história de vida. Eu vivi a dança no palco, mas efetivamente na minha adolescência isso marcou muito a minha construção corporal ao longo da vida. (Figuras 12,13 e 14)

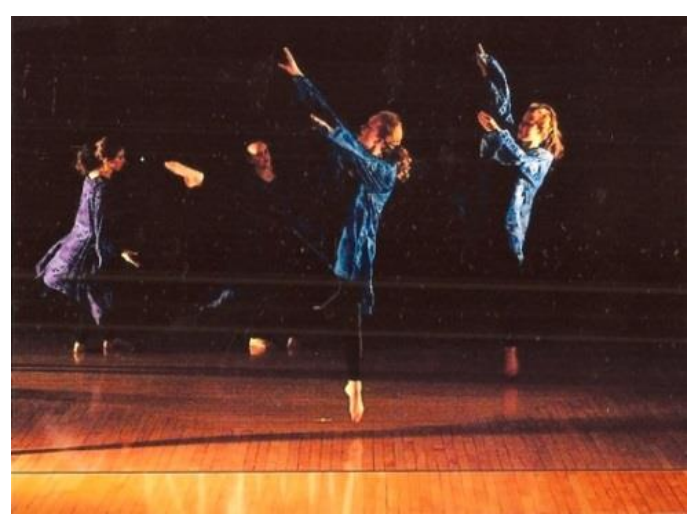

Figura 12: Imagem escolhida por Ana Paula (1) Fonte: Creative Dance

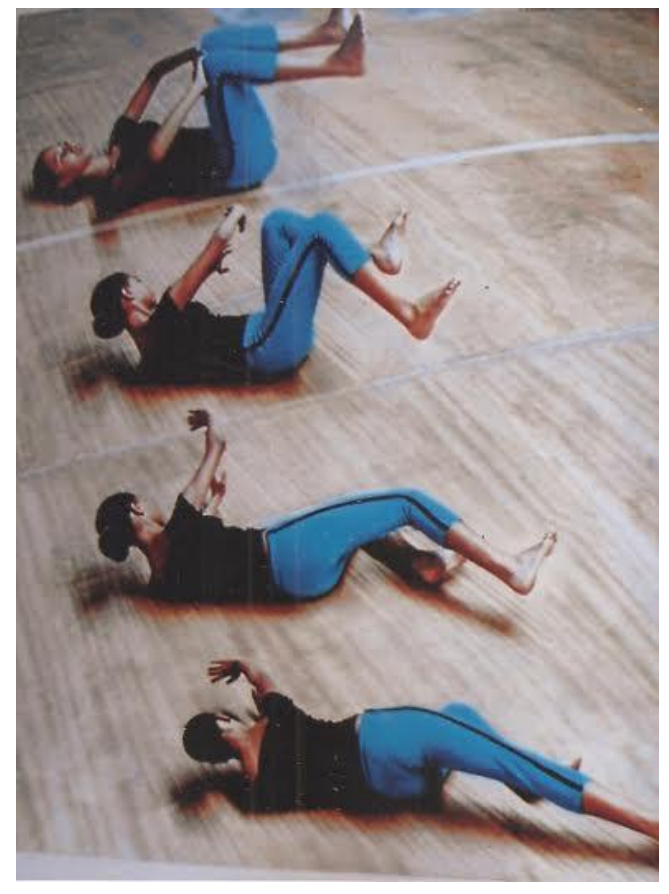

Figura 13: Imagem escolhida por Ana Paula (2) Fonte: Ivaldo Bertazzo 


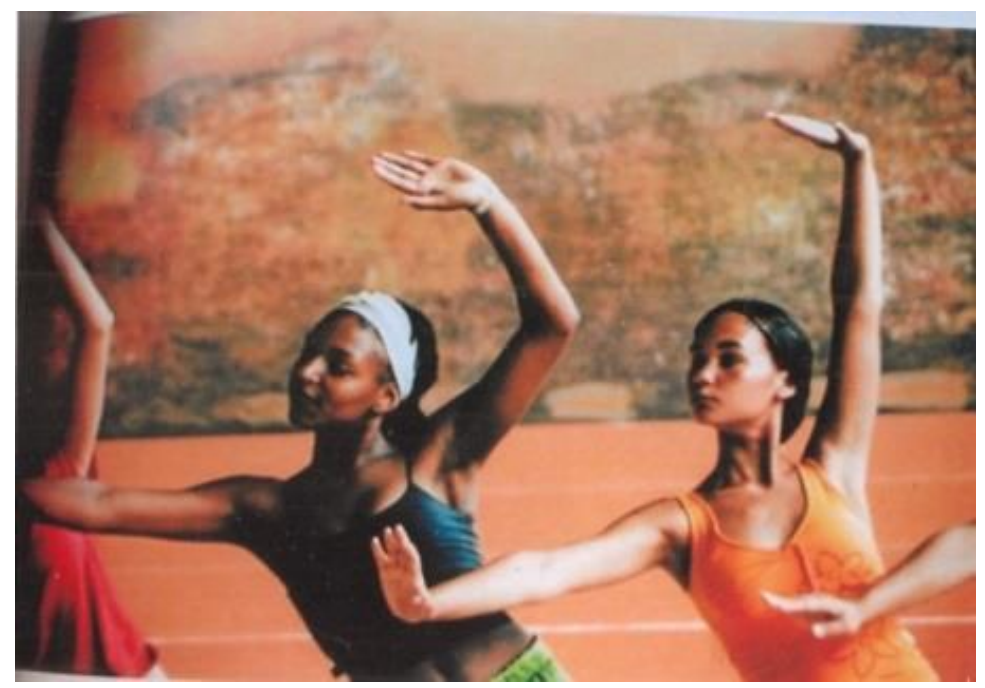

Figura 14: Imagem escolhida por Ana Paula (3) Fonte: Ivaldo Bertazzo

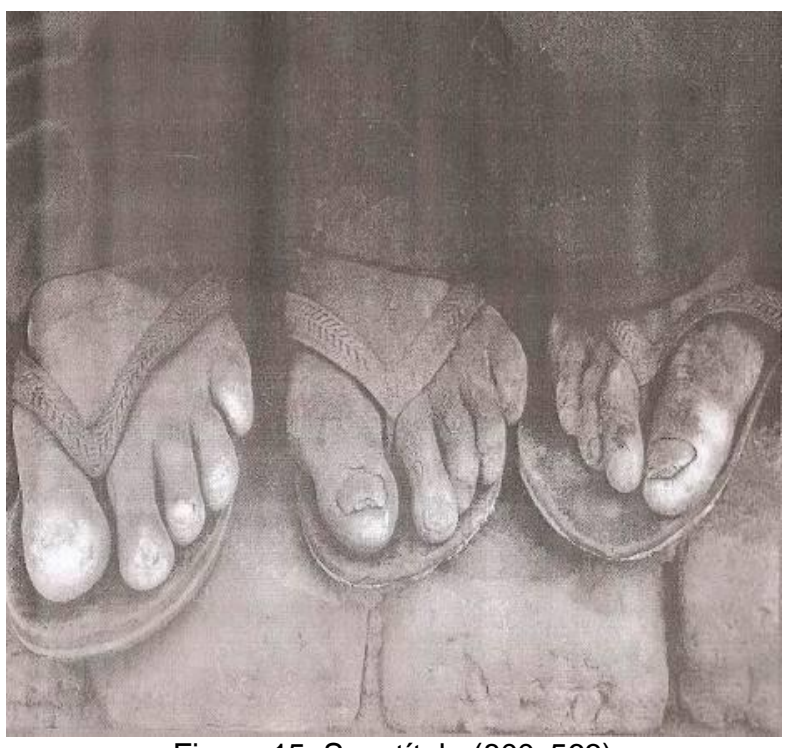

Figura 15: Sem título (800x563).

Ensaio $A$ luta pela terra, de Sebastião Salgado Imagem escolhida por Ana Paula (4)

Fonte: artenaescola.org.br

E as mãos que simbolizam o prazer e a doação que o movimento e a dança proporcionam ao ser que experimenta (Figura 16).
Os pés são os passos, e os pés que simbolizam a maturidade e o pensar esse corpo hoje que se movimenta, trabalha, um corpo já não mais dançante no palco como na juventude, mas que tem a dança marcada na sua construção ao longo dessa história. (Figura 15)

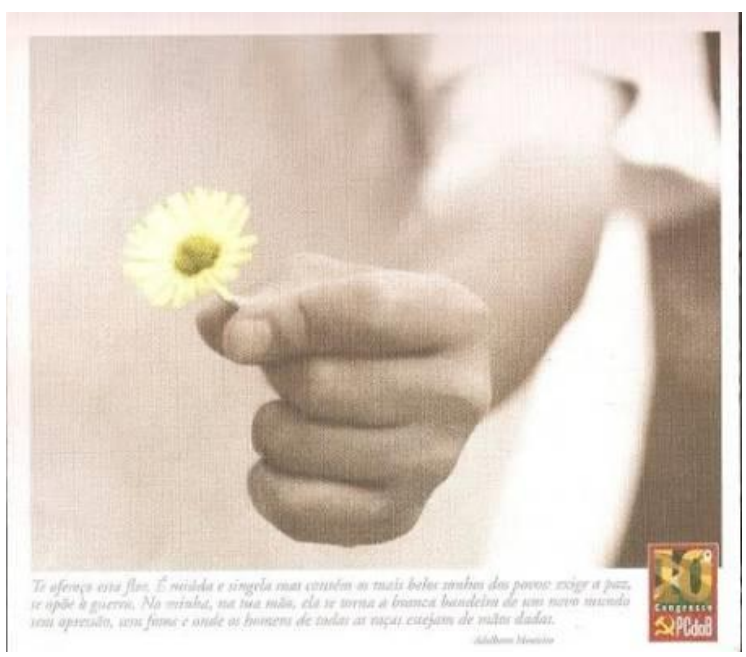

Figura 16: Imagem escolhida por Ana Paula (5) Fonte: Panfleto PcdoB 
Para Ana Paula, através das imagens, suas memórias foram acionadas e nelas se viu dançando num corpo jovem. Fez relação com suas experiências vividas no palco por esse corpo que foi jovem um dia e hoje se vê com a maturidade do movimento do ser que experimenta. Fala sobre o que a dança representa na contemporaneidade, em sua memória e subjetividade.

Também a narrativa da professora Alice deixa ver suas emoções:

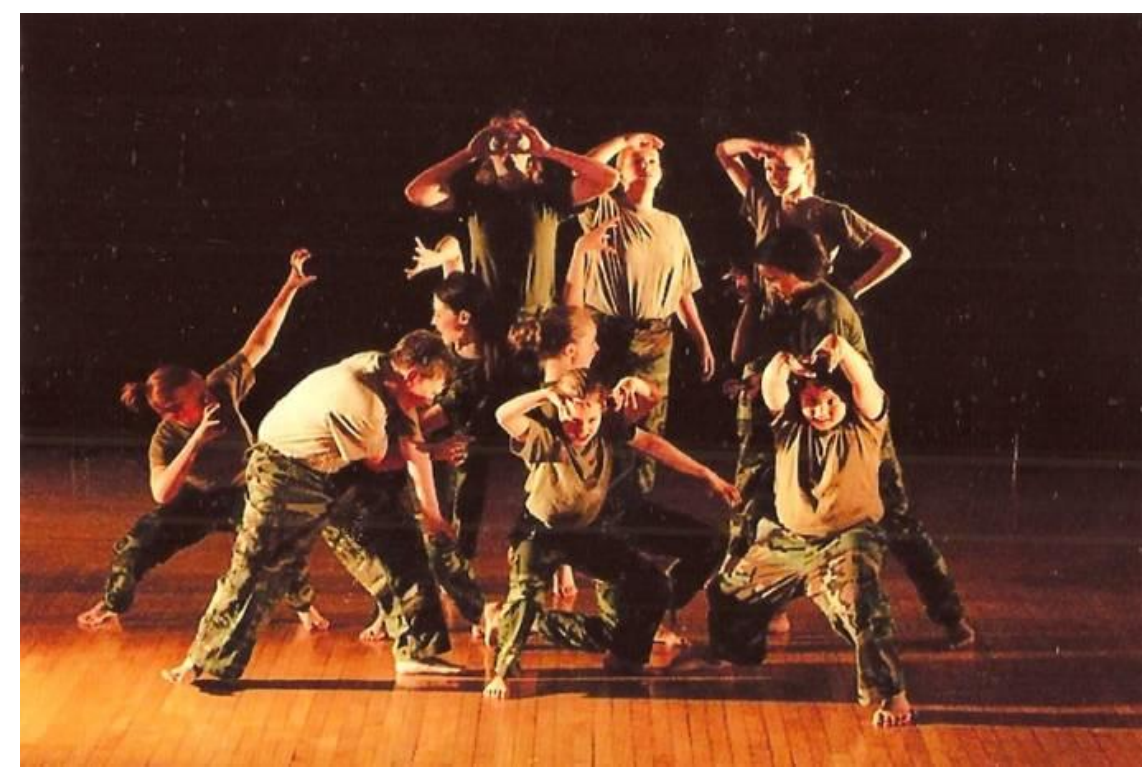

Figura 17: Imagem escolhida por Alice (1) Fonte: Creative Dance

Escolhi essas imagens porque me fez lembrar das danças populares da época em que eu estudava. Fez parte da minha vida, da minha infância: a quadrilha, o forró, as danças populares brasileiras, as cirandas. Essa primeira imagem escolhida me fez lembrar os movimentos e a cultura do hip hop, as danças de rua, o street dance, o break. (Figuras 17 e 18)

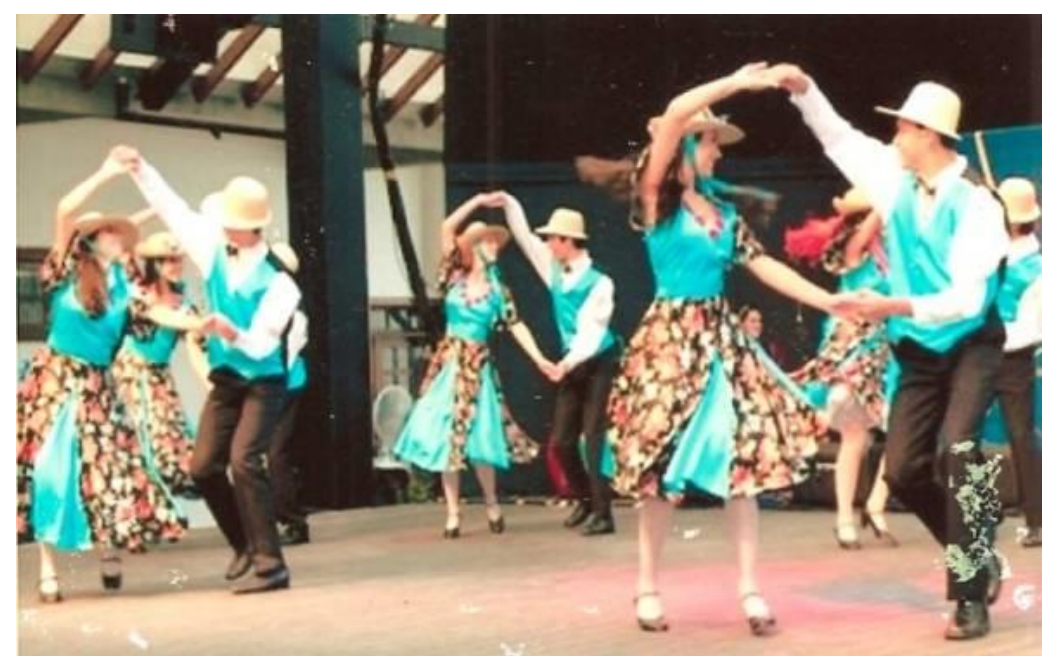

Figura 18: Imagem escolhida por Alice (2) Fonte: Grupo Aruanda - MG 


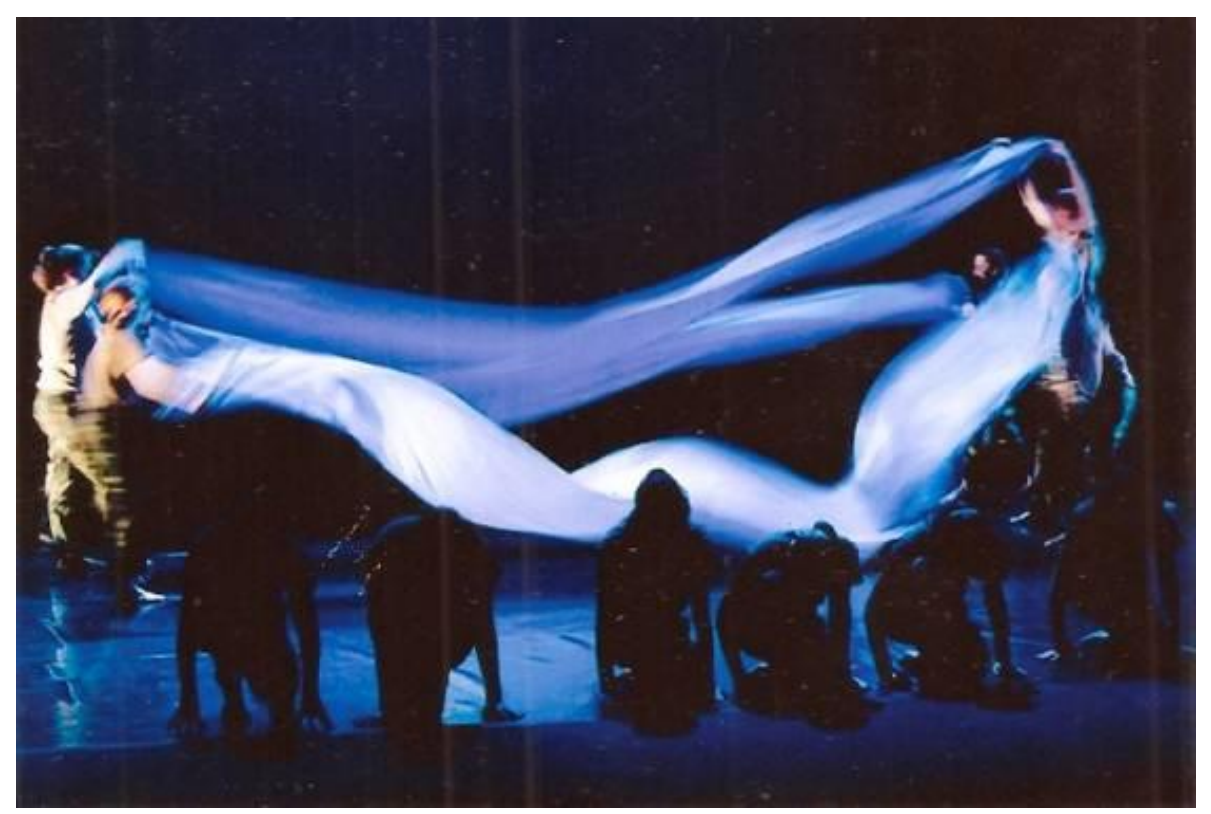

Figura 19: Imagem escolhida por Alice (3) Fonte: Creative Dance

As outras imagens me chamaram bastante atenção para as danças populares brasileiras, a cultura de cada região, os figurinos, os movimentos de cada localidade, a dança e a cultura de cada região em específico, o folclore brasileiro: o forró, o xaxado, o frevo, a catira, também dança contemporânea, o circo, os movimentos circenses e seu gênero teatral (Figuras 19 e 20).

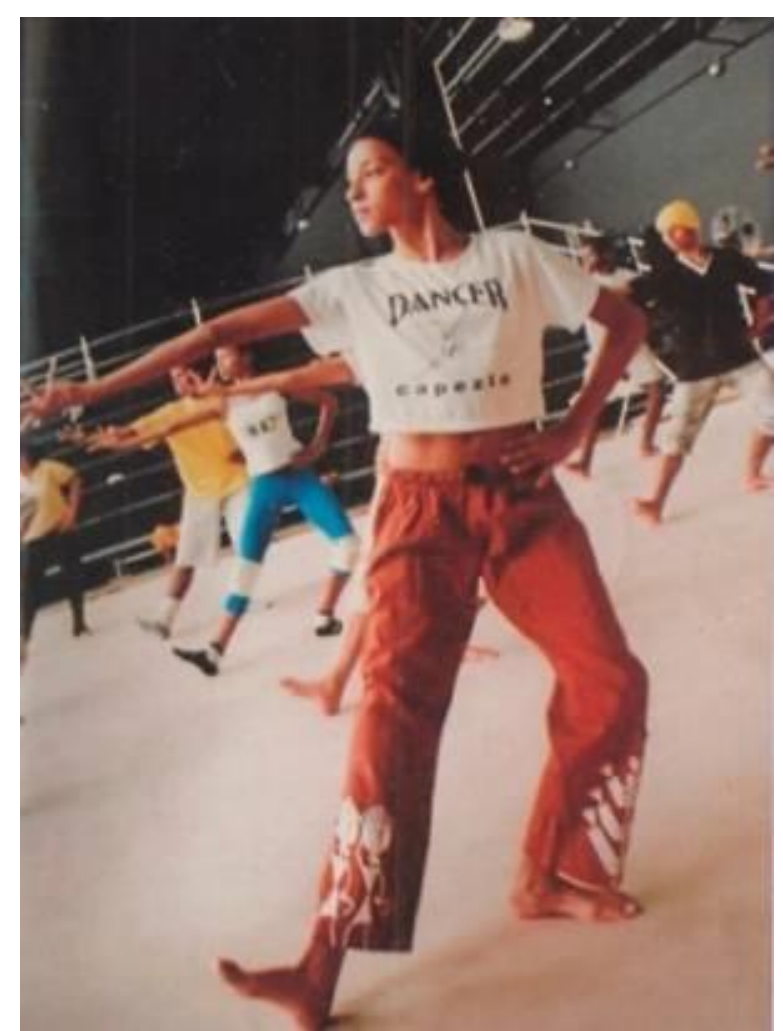

Figura 20: Imagem escolhida por Alice (4) Fonte: Ivaldo Bertazzo 


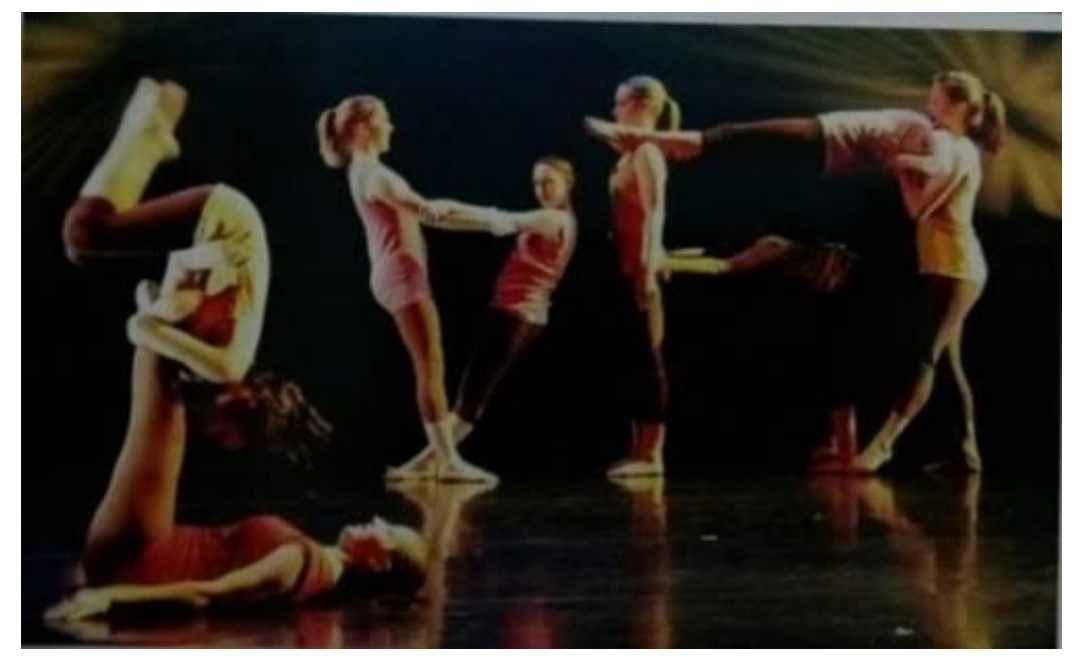

Algumas imagens também retratam as danças e o teatro e como podemos descrever e interpretar essas danças. (Figura 21)

Figura 21: Imagem escolhida por Alice (5) Fonte: Creative Dance.

Na sua memória, Alice se vê nas imagens, dançando nas festas populares da sua juventude as danças típicas de cada região, talvez pensando na escola. Um espaço de bons momentos vividos. Relata um pouco do seu cotidiano nas escolas.

A professora Cláudia diz, na sua narrativa da imagem:

Uma das imagens que escolhi foi essa parece ser um samba de roda algo parecido, primeiro é porque me interessa e me encantou a dança popular a cultura brasileira em especial. Atualmente mais porque se tornou meu objeto de pesquisa, eu tenho me aproximado muito da cultura tradicional da cultura popular brasileira, que é minha pesquisa seja, como artista ou como intérprete como também professora de dança. Tenho tentado me aprofundar nessas questões da negritude das pessoas que estão estampadas na foto, tem me instigado bastante essa relação a preconceito, racismo. Sobre essa questão da hierarquia de conhecimento de uma dança em relação à outra de um conhecimento em relação ao outro, que acaba se colocando na educação. (Figura 22)

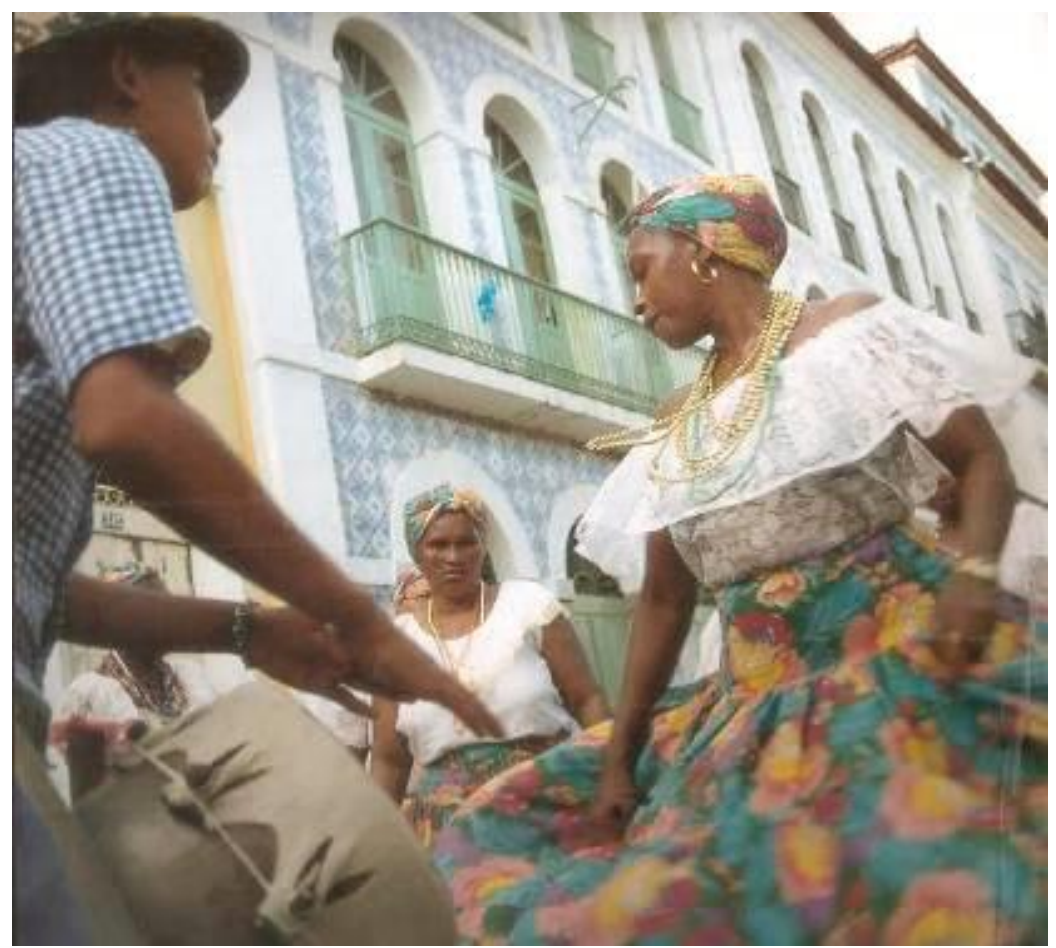

Figura: 22: Imagem escolhida por Cláudia (1) Fonte: Calendário do Banco do Brasil 
A outra imagem do Poteiro, a minha interpretação são várias pessoas dançando, várias rodas sendo formadas por várias cirandas, a escolha da imagem está relacionada ao meu trabalho atual que lugar tem esse nome de ciranda de toda essa questão que são várias cirandas, são várias perspectivas, várias possibilidades de trabalho. E também me lembra de algumas experiências que tive com meus alunos de dança pelas escolas estaduais da vida, trabalhando essa dança específica que é a ciranda de Pernambuco. Ciranda, esse lugar da educação um órgão que busca tenta, afasta se aproxima desse universo da escola, do ensino de arte e também um pouco dessa vertigem que a roda da ciranda dá, a roda do ciranda também às vezes. (Figura 23)

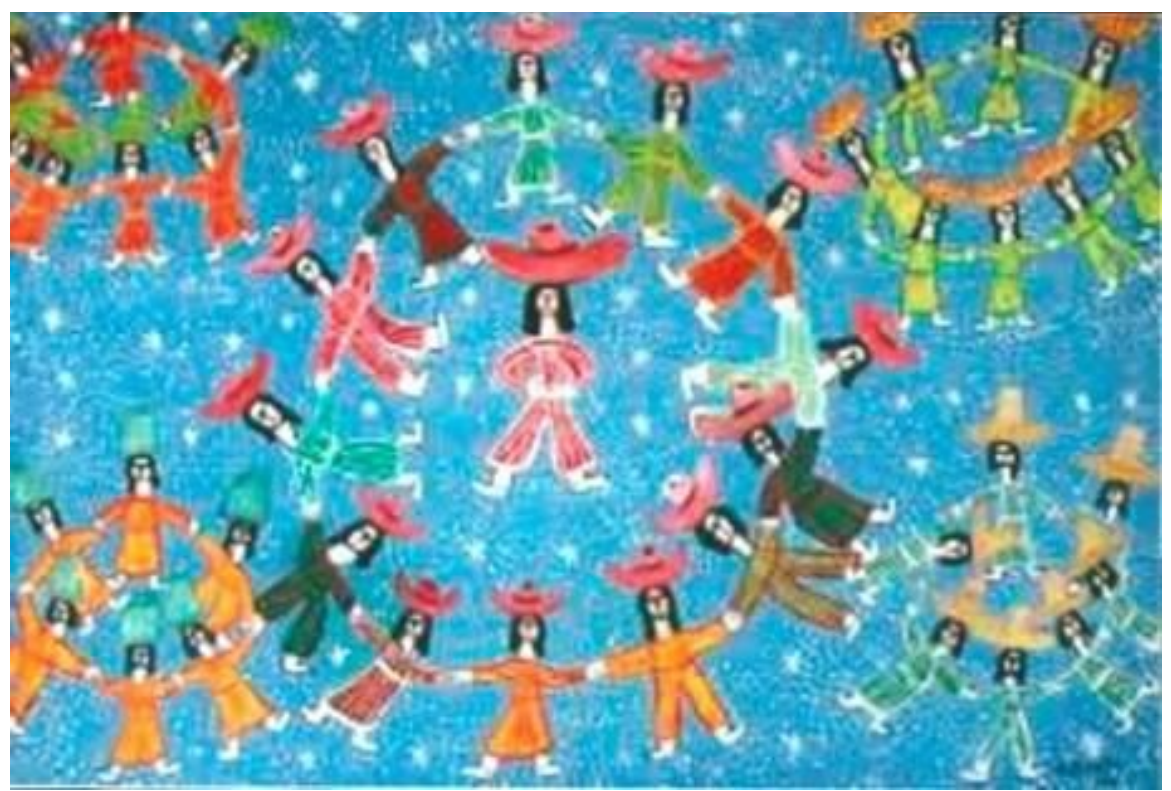

Figura 23: Imagem escolhida por Cláudia (2)

Fonte: Imagens de Poteiro (648x558). nieegaleria.com.br

Disponível em: www.catalogodaartes.com.br

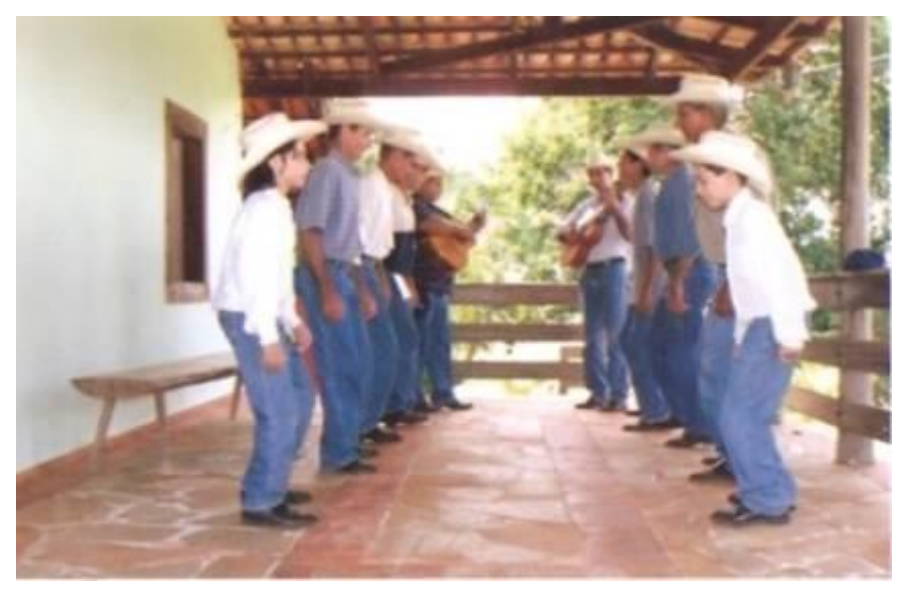

Figura 24: Imagem escolhida por Cláudia (3) Fonte: Catira / internet
A terceira imagem que eu escolhi foi essa aqui que parece uma Catira, é uma Catira, são duas fileiras de homens assim caracterizados de dançarinos de Catira. $\mathrm{O}$ motivo de eu ter escolhido essa imagem é porque a dança a cena está acontecendo não em um palco tradicional, tem mais a ver com a pesquisa que eu tenho feito agora no Núcleo Coletivo 22 que, onde eu vivencio a dança atualmente como intérprete, como dançarina e lá estamos num processo criativo em que a nossa proposta de dança de cena, elas acontecem fora do palco tradicional. Assim

não só fora, mas a primeira intenção é essa, que ela vá, assim pra mata pra terra. Tem me instigado essa coisa da dança que acontece em outros lugares. (Figura 24) 


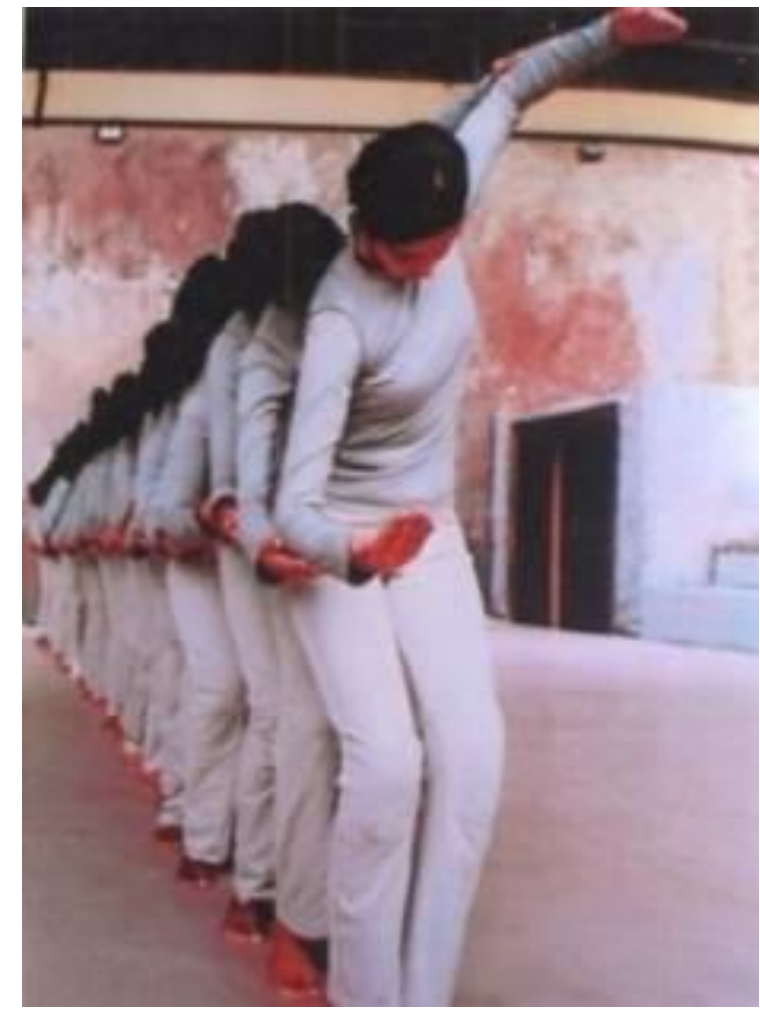

Figura 25: Imagem escolhida por Cláudia (4) Fonte: Ivaldo Bertazzo
Escolhi esta, são várias pessoas formando uma única forma complementando uma única forma dançando, e aí eu gosto disso dessa questão mesmo do outro, dessa relação de complementação de movimento que começa em uma pessoa e vai se estendendo em outros corpos; parece que é uma coisa só. Ao mesmo tempo que claro que é várias pessoas parece que é uma coisa só, é muito interessante. De como é difícil trazer essa força de relacionamento de harmonia, de troca com os alunos em sala de aula. De que eles se sintam pertencentes a um grupo só ao mesmo tempo com as suas diferenças. Me remete muito à sala de aula esse desejo que as pessoas troquem formem uma turma, digamos, que eles tenham possibilidade de, como alunos de uma mesma turma, formar uma turma coesa, sem deixar de lembrar que elas são pessoas diferentes. Além de ser muito bonito, o movimento, a sala em volta, as paredes meio descascadas, as cores meio diferentes; achei bonito. (Figura 25)

No outro movimento também parece que é uma cena de dança ou de teatro, me remete ao palco mesmo, são dois homens: um está se preparando para segurar o corpo do outro que parece vir com muita velocidade. E o que eu me interesso é porque nas minhas danças eu me arrisco pouco e estou interessada em tentar o risco, mesmo quando estiver dançando nessa sensação de desafiar o próprio corpo. (Figura 26)

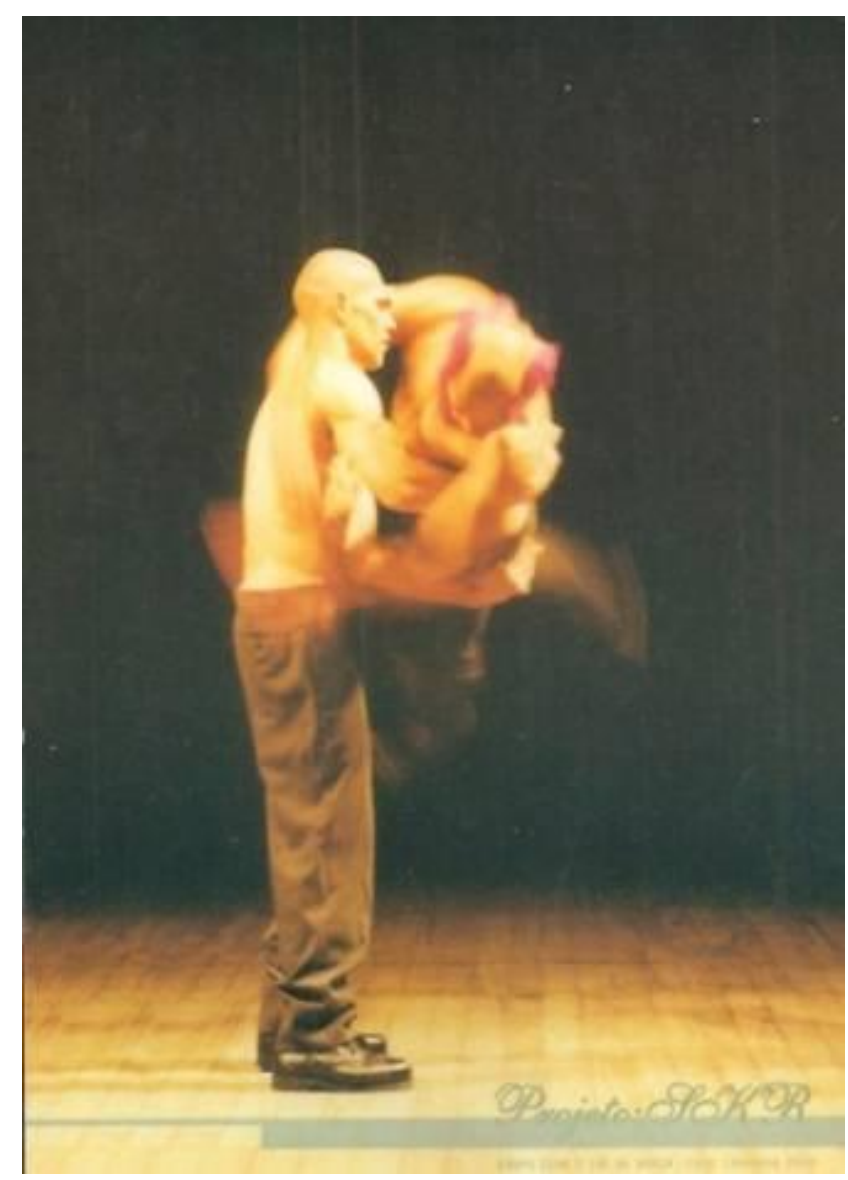

Figura 26: Imagem escolhida por Cláudia (5) Fonte: Projeto IKR 
Cláudia descreve suas narrativas com uma certa preocupação com questões que a incomodam: de reivindicações, de luta, de espaços pela igualdade, tanto social quanto política e econômica. A cultura popular tradicional também está muito presente na relação com sua pesquisa de enfrentamento das diferenças e dos preconceitos com o trato do que é cultura popular e erudita.

Assim se apresentam as narrativas e as imagens da professora Itana:

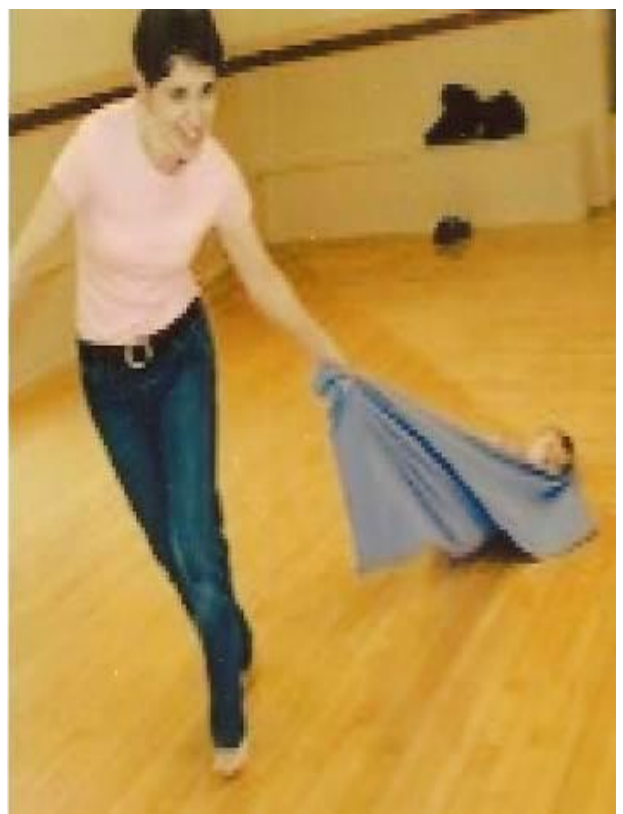

Figura 27: Imagem escolhida por Itana (1) Fonte: Creative Dance

A outra imagem foi relacionada com a folia de Reis que é uma coisa que me marcou muito. Eu ia muito às fazendas no interior de Goiás, me traz também as cores, a religiosidade, os momentos. Também trabalho quase há quinze anos com eventos culturais da cultura popular. (Figura 28).

Essa imagem que eu escolhi me trouxe um movimento da infância, de movimentos soltos de alegria, como se fosse uma brincadeira de criança bem à vontade, solta. $E$ me retratou mesmo assim a infância. Gostava, quando criança, de escorregar na garagem na água com sabão, alguma coisa assim. (Figura 27)

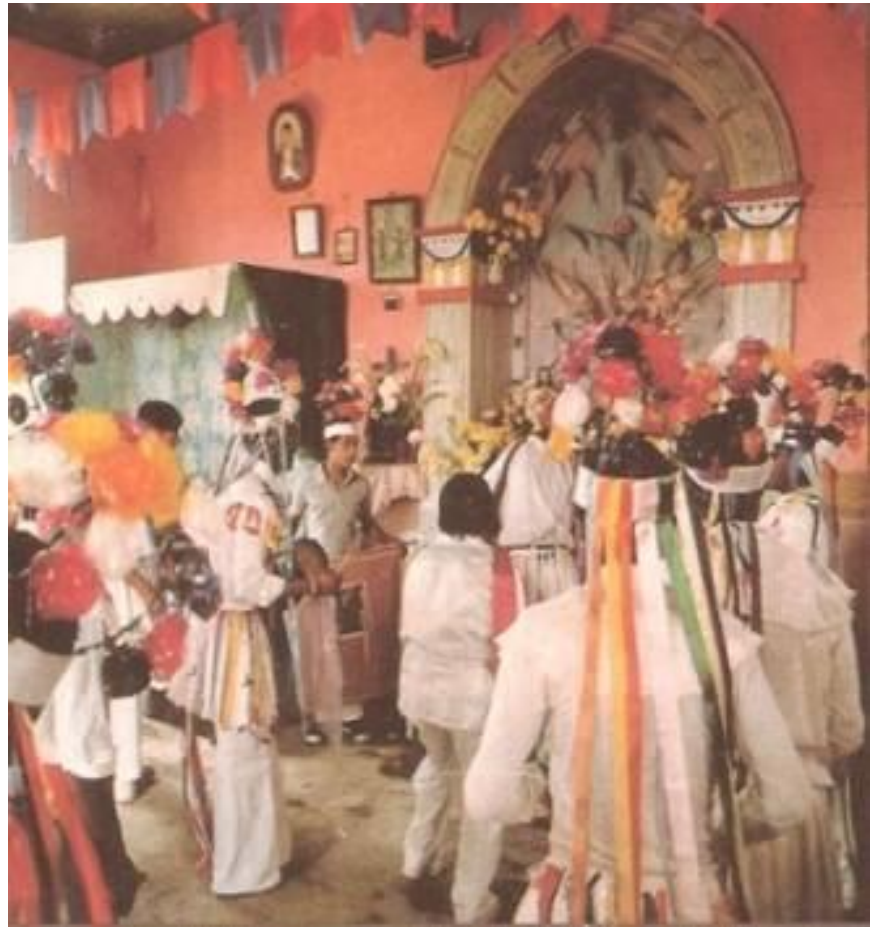

Figura 28: Imagem escolhida por Itana (2) Fonte: Calendário do Banco do Brasil. 


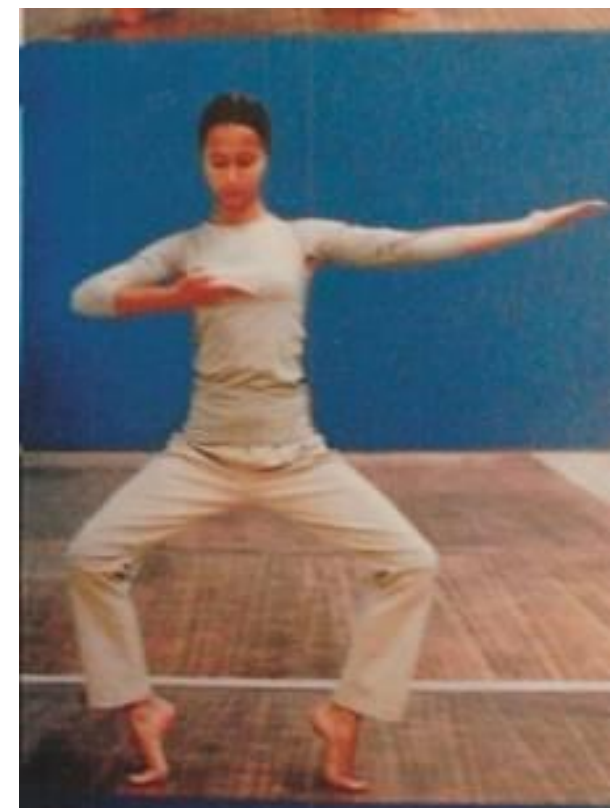

Figura 29: Imagem escolhida por Itana (3) Fonte: Ivaldo Bertazzo.

Nessa outra figura há uma alegria total alegria de carnaval de felicidades de salto de pulos de alegria de movimento de viver. (Figura 30)
O outro movimento já foi um movimento mais rígido, mas expressivo, amplo e que me lembra movimentos de início da dança moderna. Que depois vem trazendo a dança contemporânea e que me retratou muitas lembranças como também de outras experiências de escola, de dança de academia uma coisa mais dentro do meu correr da dança. (Figura 29)

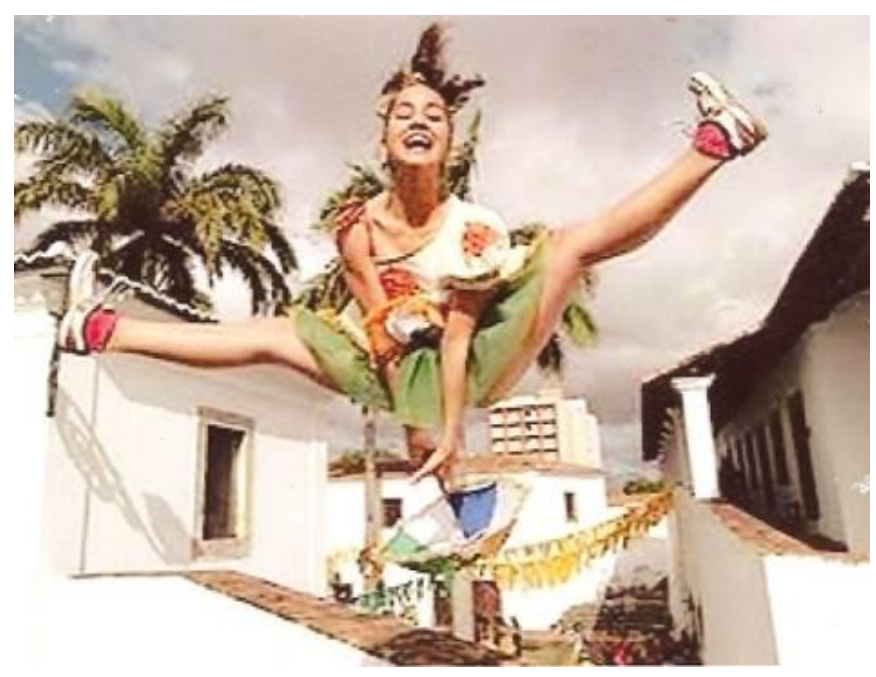

Figura 30: Imagem escolhida por Itana (4) Fonte: Frevo/ internet.

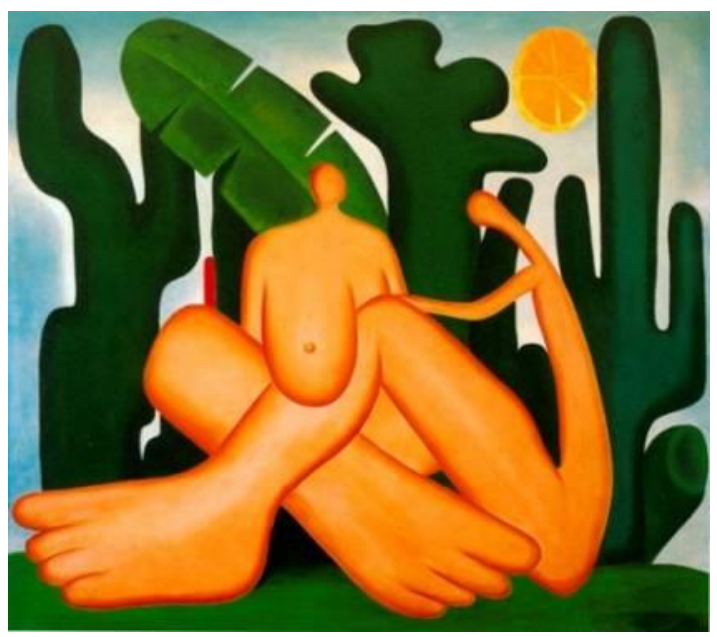

A outra imagem que escolhi, gosto muito do trabalho da artista Tarsila Amaral, que me lembro de movimentos corporais finos, limpos, grandes e muito de amor de maternidade, porque minha filha chama Tarsila. (Figura 31)

Figura 31: Antropofagia (1929) Tarsila do Amaral Imagem escolhida por Itana (5)

Fonte: Tvratimbum.cmais.com.br/trocandoarte/imagem/quadros-tarsila-do-amaral 


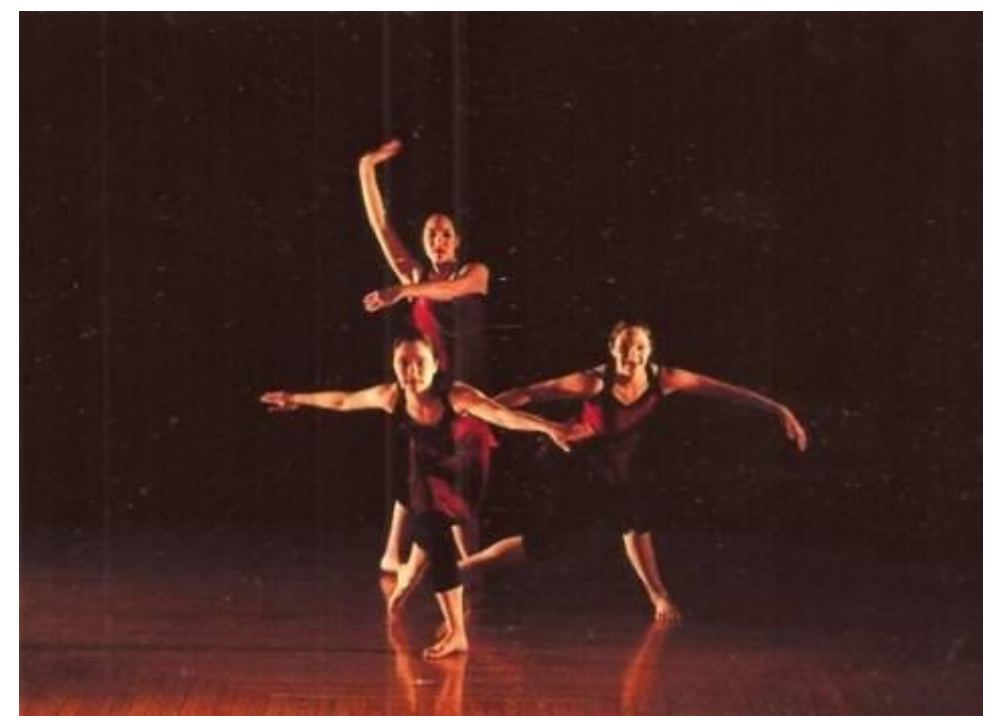

A outra imagem uma coisa de movimento expressivo, longo, de postura corporal, expressão movimento que eu gosto e que eu gostei. (Figura 32).

Figura 32: Imagem escolhida por Itana (6) Fonte: Creative Dance.

Itana relata suas memórias e um pouco de sua vida pessoal. Suas experiências estão presentes na relação com suas imagens, e fica claro todo o percurso de suas práticas até a contemporaneidade. Fala sobre sua vida e seu cotidiano.

As imagens e a narrativa da professora Mônia são assim apresentadas:

Escolhi essa imagem, que também lembra a Catira, por serem homens dançando, saltando, hoje em dia na escola eu busco muito trabalhar que é o masculino, apesar de estar muito mais em alta agora do que era antes. Esse daqui por também não fazer parte de um cenário de palco, de ser em um outro tipo de cenário que hoje se trabalha na escola, não ter um lugar específico para trabalhar. Achei que lembra muito, gosto muito do estilo da Catira, gosto da batida do palco, dos homens dançando, nesse sentido. (Figura 33)

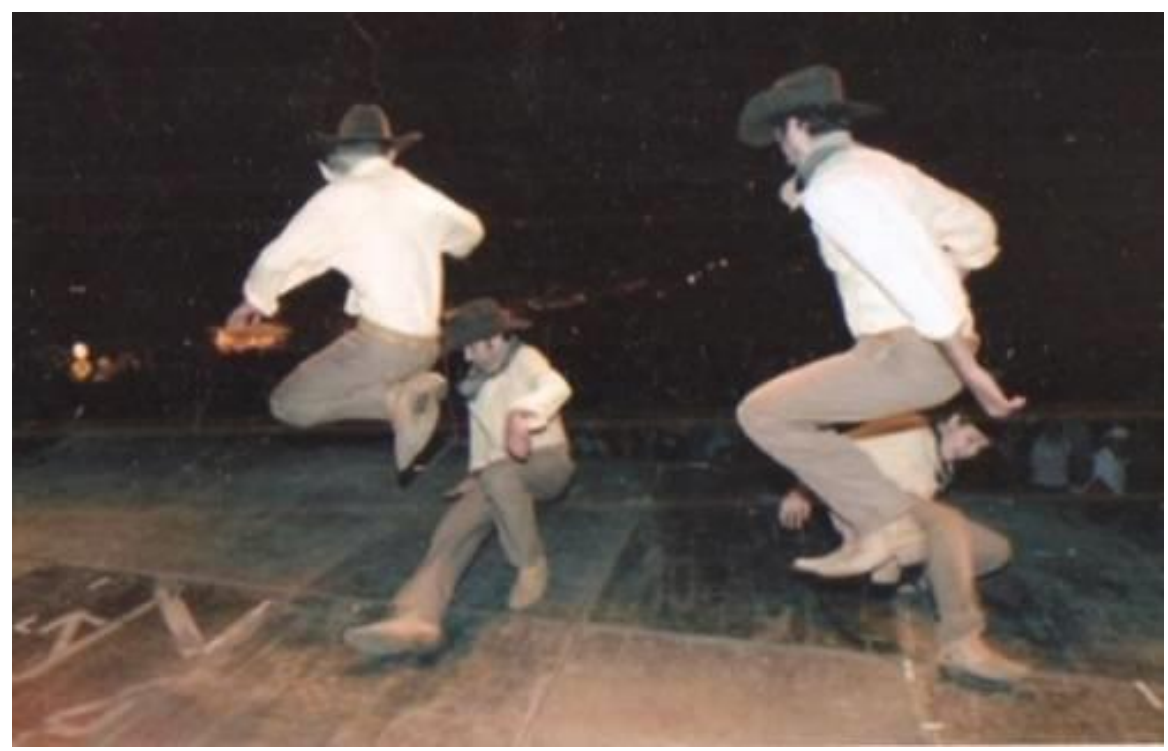

Figura 33: Imagem escolhida por Mônia (1) Fonte: Catira / internet. 
Essa outra me lembrou da ciranda, e também as danças circulares, o que vivo hoje quase tudo, até nas aulas vou ministrar como nas aulas que é evidente o círculo, cada um tem sua visão seu olhar, olhar na próxima, não há diferença entre um e outro. Vê-se que todos são capazes com as mesmas oportunidades, não tem as que estão à frente nem atrás, nem as principais, menos os que sabem todos juntos na mesma rede circundando a mesma coisa. (Figura 34)

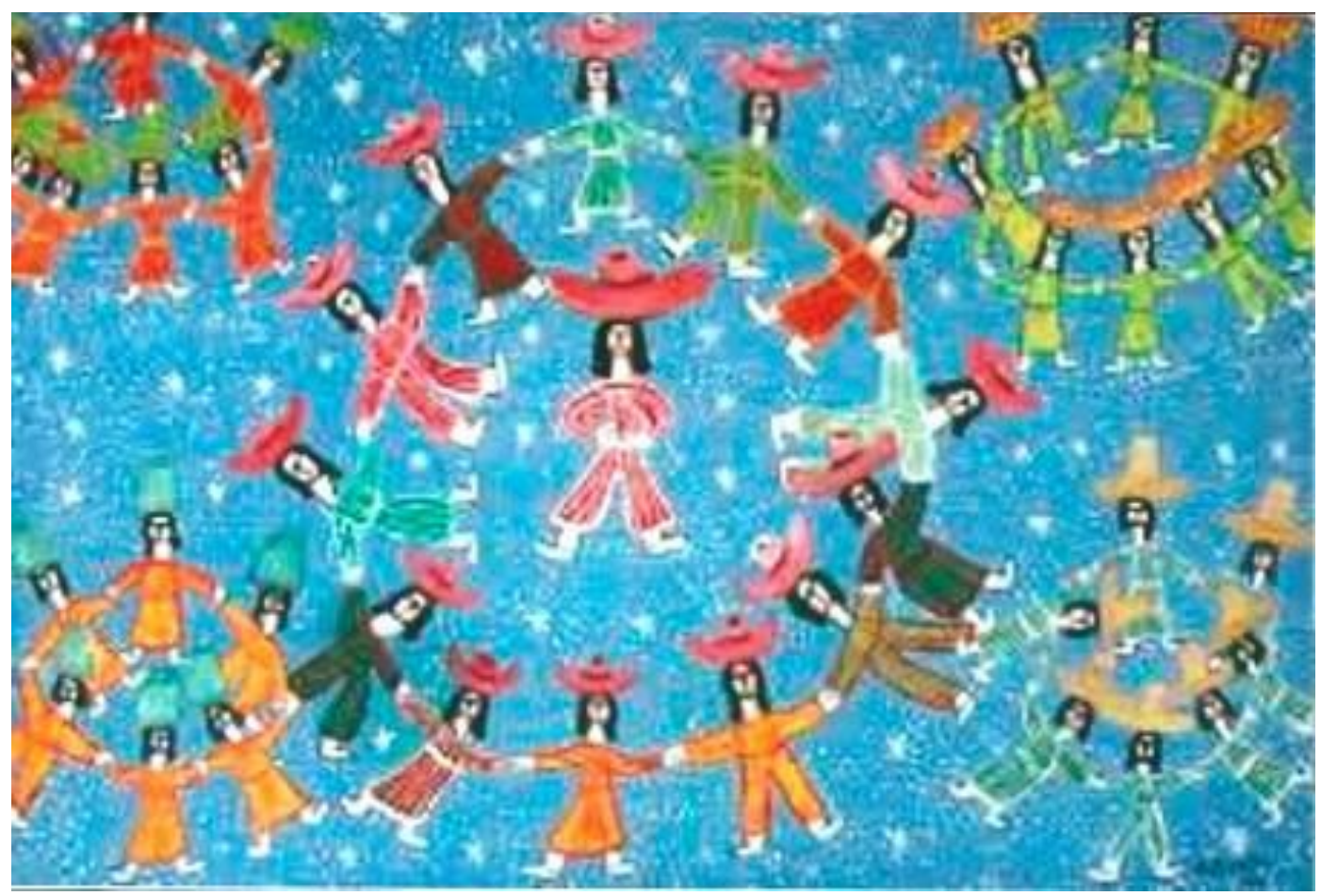

Figura 34: Imagens de Poteiro 648x558 - Imagem escolhida por Mônia (2) Fonte: www.catalogodaartes.com.br - nieegaleria.com.br

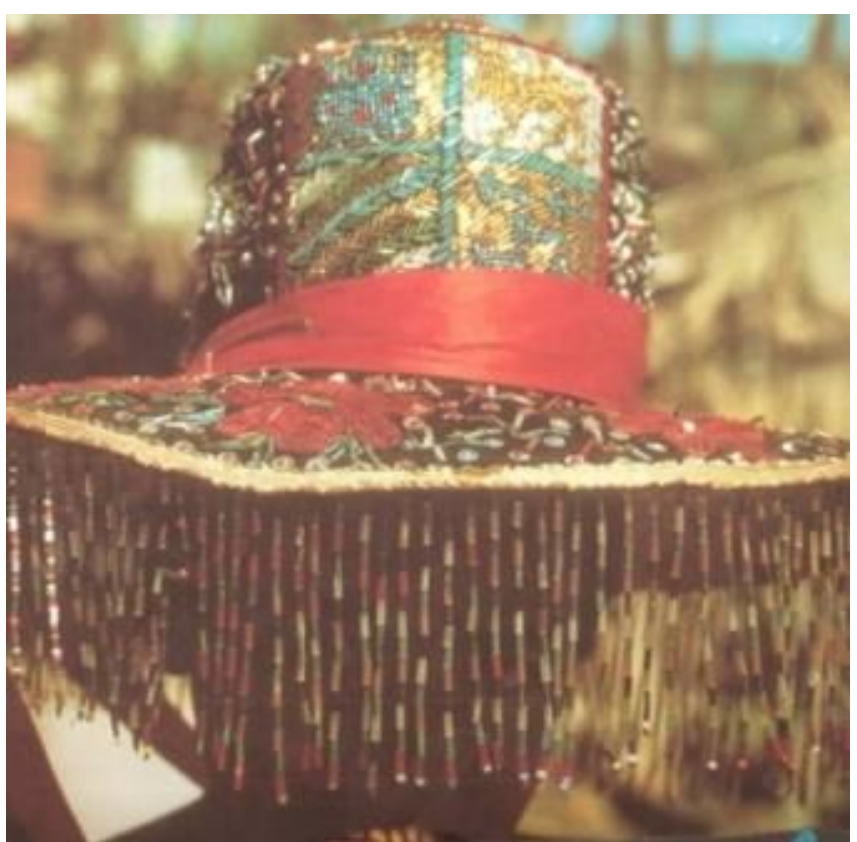

Figura 35: Imagem escolhida por Mônia (3)

Fonte: Bumba meu Boi - Calendário do Banco do Brasil.
Remete ao meu trabalho, o Bumba meu Boi nos trabalhos da cultura popular, eu sou o boi, desde que entrei no Ciranda. Saber da história dele que faz parte de todo Brasil. (Figura 35) 
A imagem do Xangô que são os negros a sua história e religião do que foi trazido da África para nós brasileiros. E o que me chamou atenção, que atualmente mais tenho buscado pesquisar. (Figura 36)

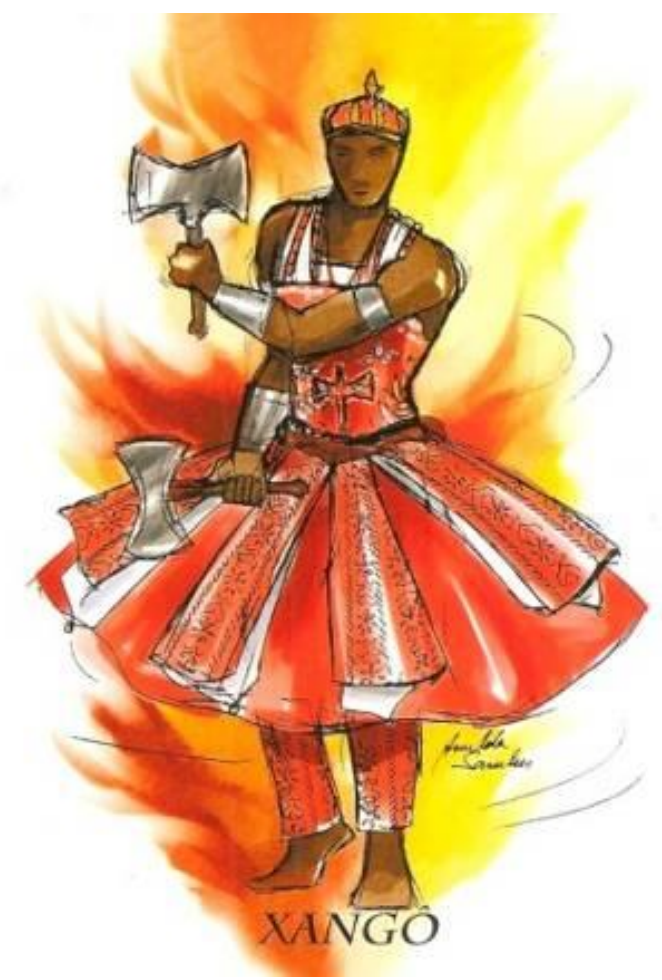

Figura 36: Imagem escolhida por Mônia (4) Fonte: Aurilda Sanches - Postal de Xangô.

Outra imagem que me lembra Maracatu. Por trabalhar sempre tanto na dança na composição quanto nas coreografias e histórias e também como pesquisa. (Figura 37)

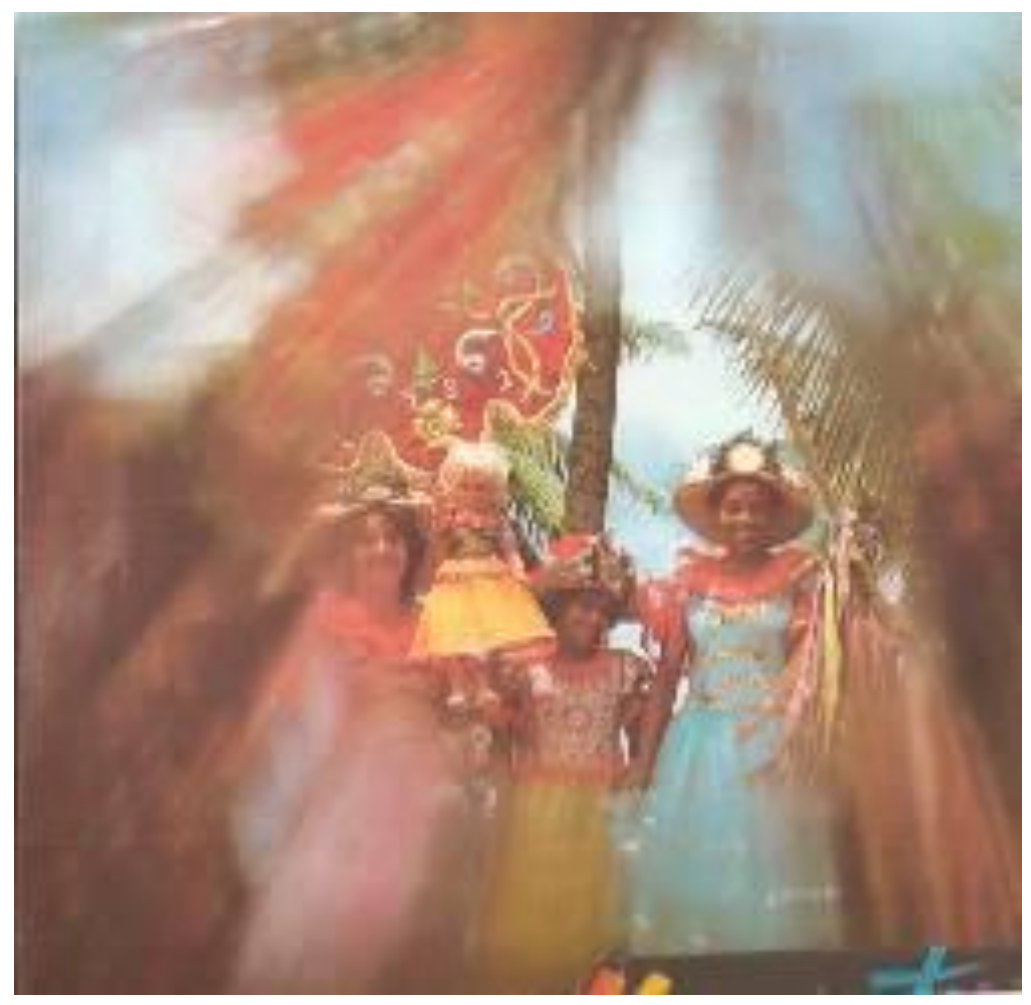

Figura 37: Imagem escolhida por Mônia (5)

Fonte: Maracatu - Calendário do Banco do Brasil. 
Aqui eu venho buscar o que chamou muito atenção por parecer a congada seria o Moçambique. Pouco que fiquei sabendo que vem da Congada e dependendo da região. Achei interessante que faz parte das histórias dos negros que também vieram para o Brasil. (Figura 38)

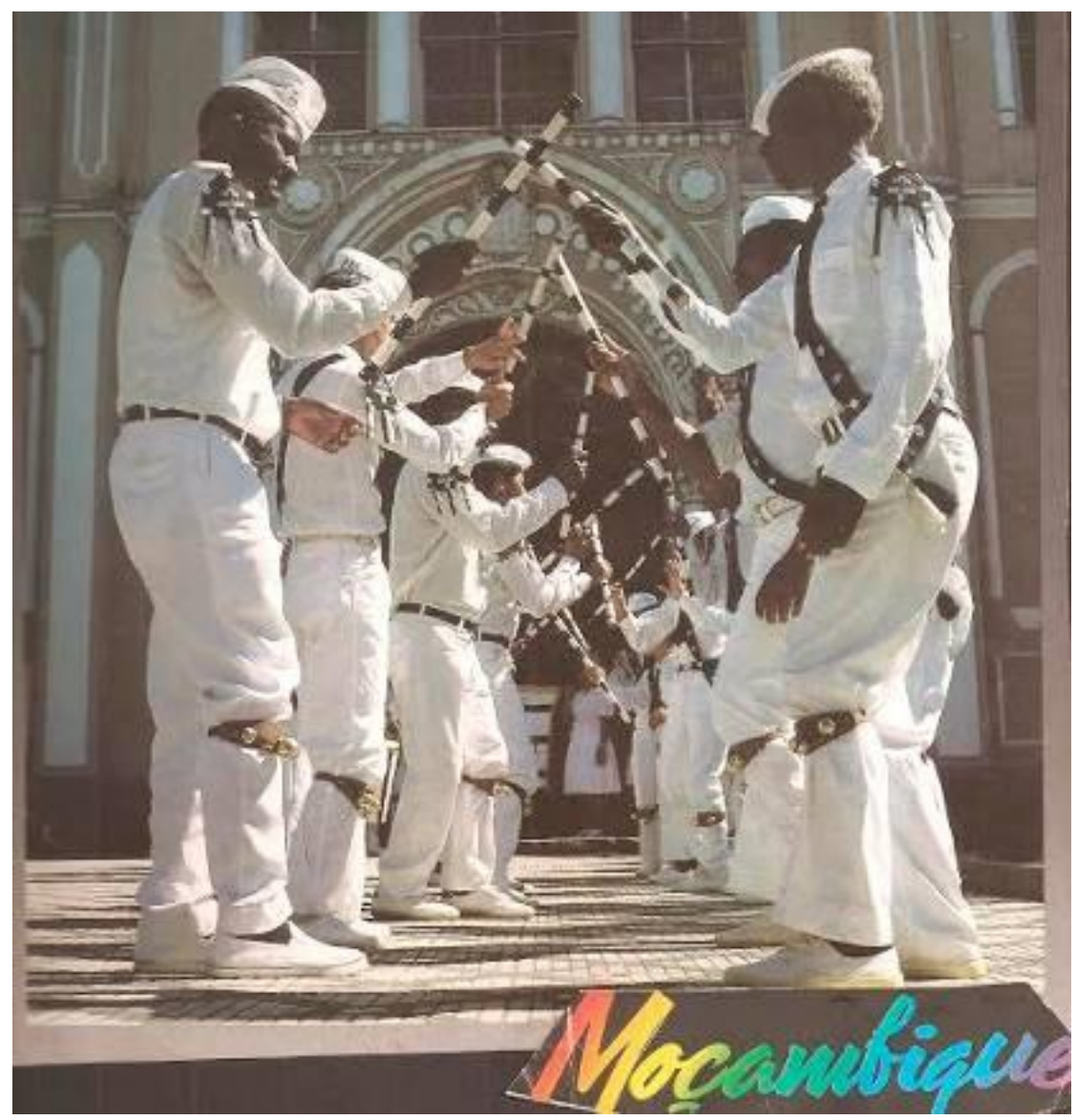

Figura 38: Imagem escolhida por Mônia (6)

Fonte: Moçambique - Calendário do Banco do Brasil.

$\mathrm{Na}$ fala de Mônia, ficam claras as suas escolhas referentes à relação próxima entre a cultura afro-brasileira e a cultura popular tradicional, o que ela vem investigando e vivenciando na escola e na sua vida. É uma professora que tem um percurso de vários anos na rede estadual de Educação. Hoje percebemos que já tem bem definida sua área de estudo e atuação para o ensino de dança.

As escolhas pessoais das professoras revelam que, ao se verem e serem vistas, fazem as conexões com seu cotidiano, sua história de vida, sua cultura e identidade. Aprender a ver não é reconhecer a imagem como objeto, é também dar significado ao envolvimento com os detalhes significativos das imagens. Cada uma das imagens atribui significados, em função da cultura que a envolve, para a compreensão de cada grupo. Como Tourinho ( 2011, p.11) enfatiza, "[...] a amplitude da questão do ver e ser visto que inclui não apenas as imagens que vemos, mas as 
imagens e artefatos através das quais nos vemos. Inclui, também, como as imagens nos veem". As narrativas das imagens ganham significados no encontro entre 0 mundo da dança e o percurso no ensino.

Ao construir as narrativas visuais e depois orais sobre as imagens, constroem-se diálogos com o imaginário criativo, que se referem aos significados de ideias percebidas, vivenciadas, sentidas, inscritas e imaginadas no corpo. processo de criação vem se construindo a partir da relação com o mundo imagético, que gera significados para cada dançante.. Como afirma Meira (2003, p. 52):

\begin{abstract}
A imagem tem um papel virtual agregador de significados, formas, comportamentos reais no cotidiano vital. Imagens mostram a exterioridade dos fenômenos intersubjetivos que se concretizam em gestos, formas, agenciamentos culturais, através dos quais a sociedade exerce sua criatividade. O campo imagético é a cultura visual atual, o contexto estético de nossa experiência sensorial, a parte e o todo que nos toca ver para situar nossos saberes, nossos afetos, nossas percepções, além de um complexo mundo de formas ligadas a obras e processos de criação.
\end{abstract}

Nesse processo de criação que se materializa na reflexão sobre essa ação cênica do corpo preparado para a cena, se manifesta o imaginário criativo. Com intuito de criar uma rede de conexões com as imagens, foram gravadas as narrativas orais, utilizadas para mobilizar o processo criativo do dançante. Essas gravações serão utilizadas para interação das cenas na produção das "Poéticas do corpo em cena".

\title{
2.3 Elaboração das Matrizes de Movimento e o Corpo em Cena
}

A seguir exporemos o processo de construção das matrizes de movimento, das narrativas imagéticas para levar o corpo para cena, na criação das "Poéticas do corpo em cena". Os elementos constituintes dos movimentos reconhecidos, inscritos nas imagens, no ver e ser visto, reverberam nesse corpo dançante para a construção da matriz de movimento que toma forma e ocorre processo de construção da cena. Segundo Mota (2012. p.63, p.64):

A partir de princípios básicos, Laban chegou à conclusão que era possível reconhecer a finalidade de certos movimentos, se respondidas as questões: o que se move? Onde se move? Quando se move? Como se move? A resposta a estas questões formaria a resposta para uma questão maior: por que se move? Laban deduzia que seria possível entender o que motiva as pessoas se moverem. 
Assim, mediante o entendimento do movimento e de suas funções é possível dar sentido e significado para essa ação de se mover na construção de uma matriz de movimento. A materialização dessas narrativas das imagens se dá na ação associada ao movimento estruturado em frases, com múltiplas variações no espaço, nas dinâmicas e nos relacionamentos, fundamentados nos elementos da linguagem do movimento com base nos estudos da Coreologia, segundo a teoria de Rudolf Laban.

Conforme essa teoria os princípios de ordem e harmonia que orientam o movimento são organizados segundo valores pessoais, culturais e emocionais e com uma lógica interna que estrutura o sentido da própria dança, das emoções, dos sentimentos e dos valores que a integram. Como relata Ramos (2007, p.20),

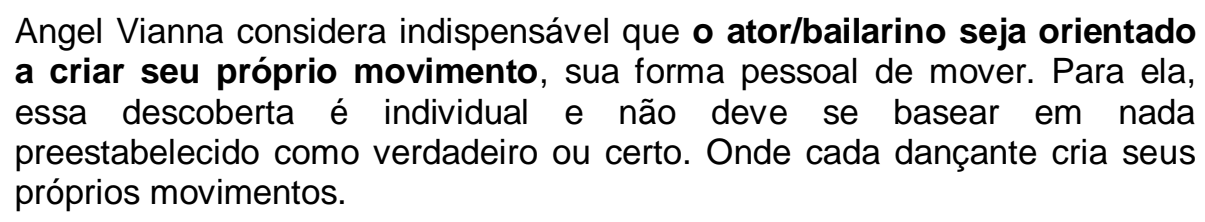

Angel Vianna considera indispensável que o ator/bailarino seja orientado a criar seu próprio movimento, sua forma pessoal de mover. Para ela, essa descoberta é individual e não deve se basear em nada preestabelecido como verdadeiro ou certo. Onde cada dançante cria seus próprios movimentos.

Assim revela a Figura 39.

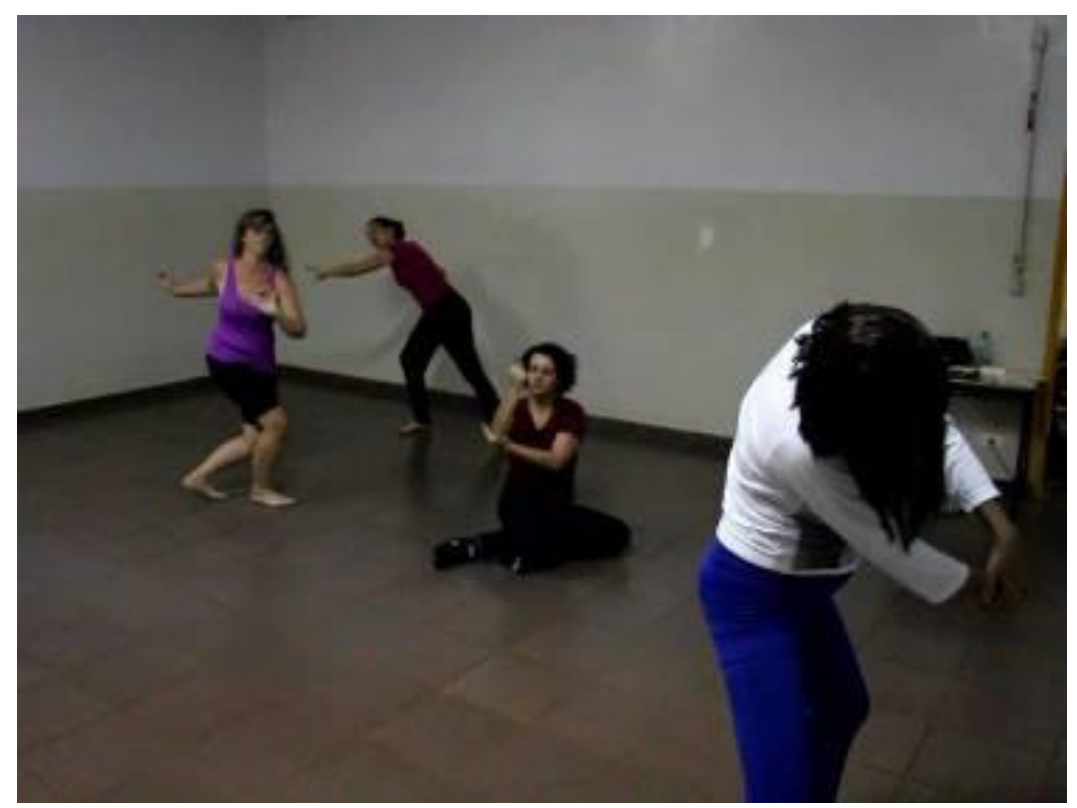

Figura 39: Criação da matriz de movimento Fonte: Integrantes do grupo.

Ao elaborar células de movimentos em forma de composição coreográfica, cria-se uma matriz (Figuras 40 a 45) que promove o diálogo da estética elaborada e estruturada pela identidade de cada dançante, com as imagens escolhidas no universo imagético (Anexo 1). Para se compor em dança, acentuam Lobo e Navas 


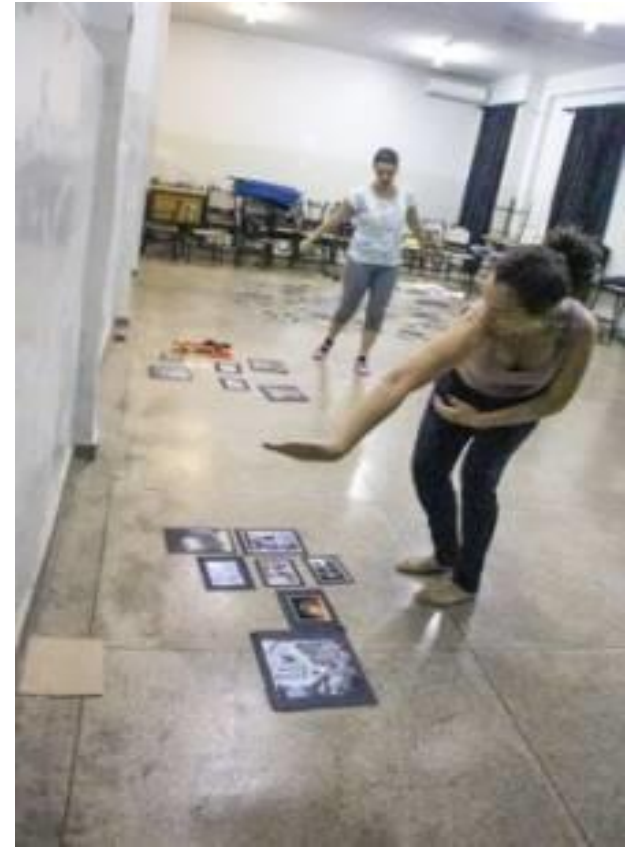

Figura 40: Elaboração da matriz Fonte: Integrante do grupo.
(2008, p. 25), "é necessário muito mais do que o ato de dançar. É partir do processo criativo para dar forma à composição cênica, o que em dança chama-se de coreografia, que em grego quer dizer a grafia de danças corais, danças de grupo." Ao concluir a matriz de movimento, a composição é apresentada ao grupo para que todos possam ver; olhar; se reconhecer, reconhecendo os elementos constituintes do movimento nas imagens; rever as memórias, experiências e relações com a sua vida; e tomar forma na ação cênica.

\section{Relata a professora colaboradora Mônia:}

Passamos a criar a matriz e durante o processo criativo éramos sempre provocadas pela turma, criava uma sequência e assim que mostrava a turma tinha também interferências e a imagem das figuras vinha a minha mente sempre que criava ou modificava a sequência. Em cada dia e momento eu sentia diferença no meu corpo e na minha sequência de movimentos que trabalhava, acredito que cada encontro na elaboração da matriz que chegava e via as imagens, dependendo dos acontecimentos anteriores ao horário do encontro, influencia e muito na construção e elaboração da matriz. (Figura 41)

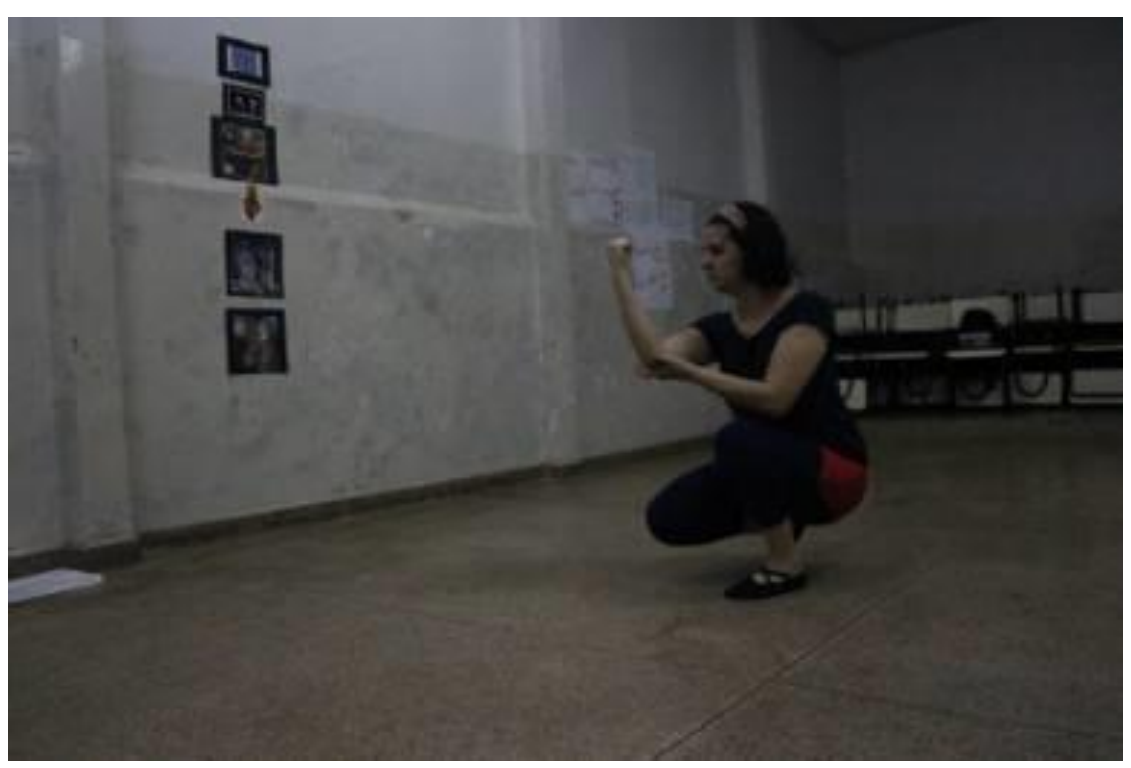

Figura 41: Elaboração da matriz Fonte: Integrante do grupo. 


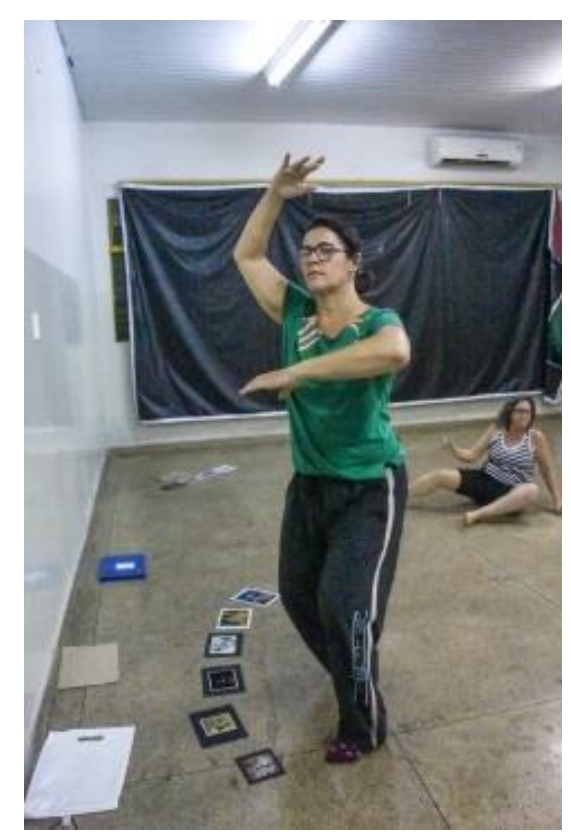

Figura 42: Elaboração da matriz Fonte: Integrante do grupo

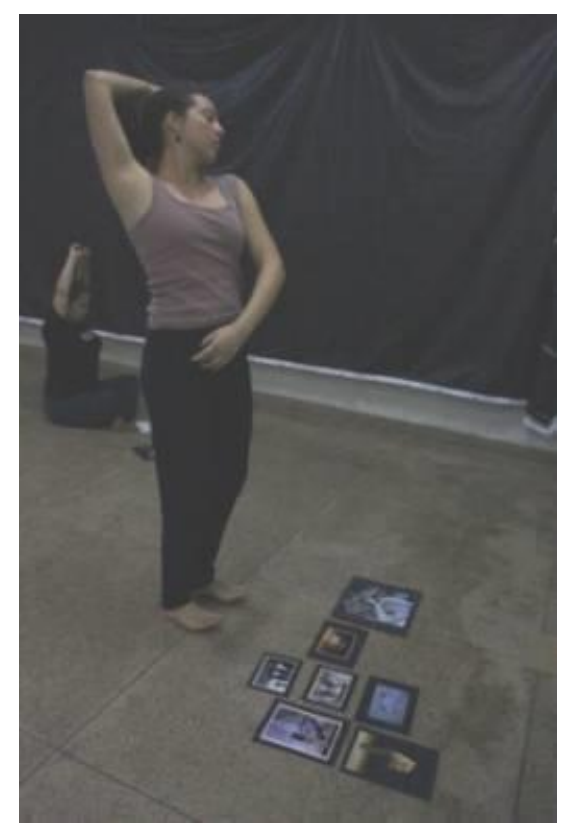

Figura 44: Elaboração da matriz Fonte: Integrante do grupo.

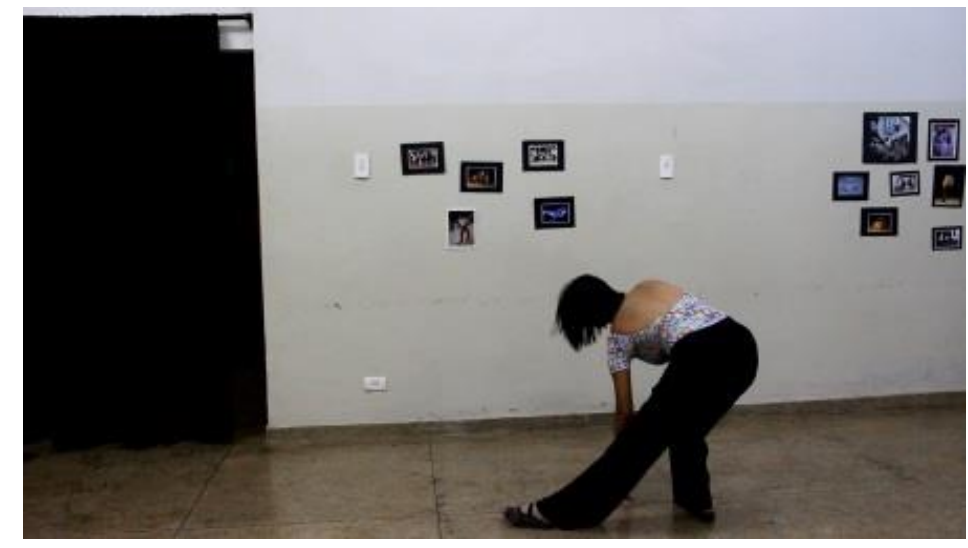

Figura 43: Elaboração da matriz Fonte: Integrante do grupo

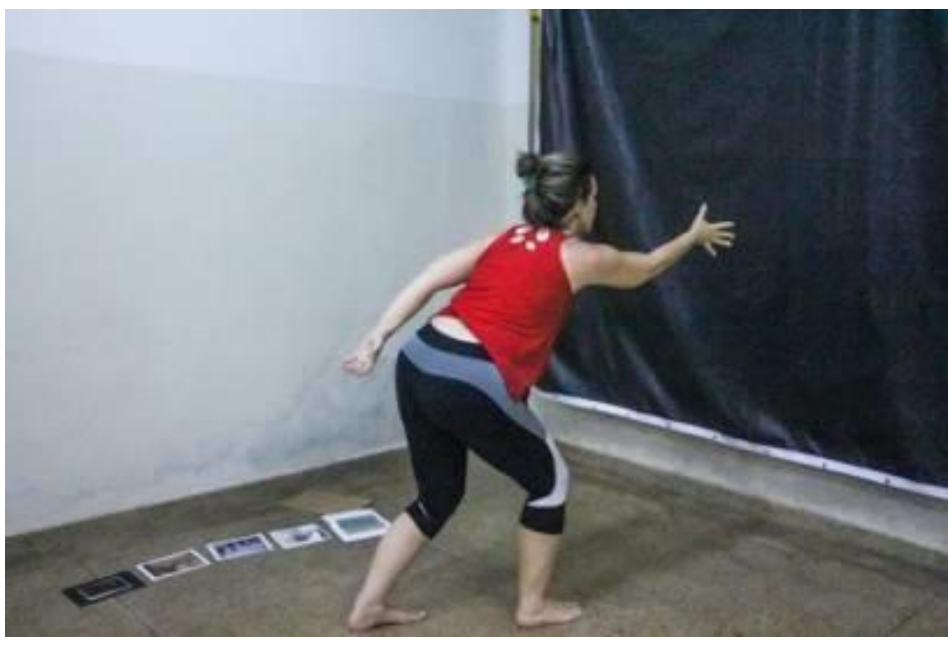

Figura 45: Elaboração da matriz Fonte: Integrante do grupo.

Cada intérprete-criador, com sua matriz de movimentos, propõe-se à construção de jogos corporais de interação com movimento presente, trazendo à tona traços de afinidade, junção e disjunção individual, revelando a multiplicidade de experiências estéticas, autorais, dialógicas e colaborativas. Conforme Ramos (2007, p.44), 
os Jogos Corporais são hoje definidos por Angel Vianna como uma "improvisação que é ao mesmo tempo uma criação musical e teatral"... Os jogos corporais dão aos participantes a oportunidade de experienciar uma movimentação fruto de um relacionamento espontâneo com o outro ou com um objeto. A intuição e a espontaneidade são as principais características que os jogos corporais despertam.

O corpo passa a ter como característica respostas rápidas, a perceber e a preencher espaços vazios existentes, projetando formas para outras direções no espaço total, com envolvimento e liberdade pessoais. Angel Vianna acredita, portanto, "que ninguém ensina nada a ninguém" e que a aprendizagem se dá mais pela experiência.

O importante nos jogos corporais é estar com o corpo presente, disposto a ser criativo e observador, na escuta do outro para compartilhar e trocar experiências. Sua principal característica é despertar a intuição e a espontaneidade, pois se pede que as respostas sejam rápidas, sem construção mental. Prossegue Ramos (2007, p.45):

No ato de jogar, a pessoa tem liberdade para agir a fim de alcançar seu objetivo. O único compromisso é com as regras do jogo. No caso dos Jogos Corporais, essas regras determinam os estímulos iniciais para que a movimentação se inicie. Daí para frente, o como fazer é sempre ditado pelos participantes.

O jogo não deve ser confuso, deve ser simples com objetivos bem claros, no intuito de aumentar a percepção, liberar e conhecer o corpo. Nas composições dos movimentos não existe o certo e o errado. O importante é que o trabalho faça o dançante perceber o corpo com alegria, com prazer.

Através dos jogos corporais podem-se construir cenas em que estipulam os encontros e o número de participantes, elaborando um trabalho de composição instantânea. Composição instantânea é um encontro criativo, com regras que fornecem uma estrutura planejada e marcada. A música, por exemplo, não é planejada para cada movimentação dos corpos na cena simultaneamente, também não é determinado, preestabelecido, o ritmo. Pode-se também, ao utilizar os jogos corporais, determinar quantos encontros se dão durante o jogo em cada cena, preenchendo o espaço. Destaca Ramos (2007, p. 51):

No Jogo Corporal é importante saber se relacionar com o espaço, saber jogar com o outro, saber, principalmente, perceber o outro. Por meio dos Jogos, em especial os atores, não passem pela vida sem notar que existe um espaço que é ao mesmo tempo limitado e amplo. 
No jogo corporal os dançantes assumem plena consciência dos seus espaços - o pessoal e o da sala de aula - com base na presença do outro. Sem o outro não há jogo, pois o corpo joga percebendo a si próprio ou a dupla, o trio, o quarteto. No trabalho é proposto jogar com suas matrizes de movimentos e também com os planos, com os níveis desse espaço e com as dinâmicas, para que tenha o corpo jogando, percebendo e sentindo o ambiente - usando-o em toda sua dimensão. Criam-se, assim os desdobramentos de elementos composicionais no processo de criação da dança em cena.

\section{4 "Poéticas do Corpo em Cena"}

Esses são momentos únicos e singulares do corpo, nas experiências estéticas que se dão ao longo do tempo e do espaço no processo criativo como uma arte efêmera. Como afirma Meira (2003, p. 32), a "experiência estética coloca a cognição em permanente desconstrução e reconstrução, pela vulnerabilidade aos acontecimentos, estados de espírito, relações com a cultura, saberes múltiplos vindos do corpo, do ambiente, da memória e ficção". Tais experiências se dão ao longo do tempo e do espaço e vão se transformando e gerando múltiplas formas de interpretação do corpo em cena. Uma característica necessária às cenas é que os dançantes envolvidos procurem perceber e preencher os espaços vazios existentes, projetando formas para outras direções no espaço total.

O processo criativo em dança aqui exposto acontece através das experiências estéticas da ação cênica e do corpo em cena: criam-se cenas, cada uma com suas especificidades, sem tempo determinado para acontecer: Cena I Universo Imagético; Cena II - Singulares; Cena III - Diálogos Corporais; Cena IV Conexões rizomáticas; Cena V - Poéticas dos Diálogos Composicionais; Cena VI Desdobramentos Composicionais; Cena VII - Singulares/Simultâneas. As cenas serão acompanhadas por um vídeo interativo, com imagens captadas em sala de aula durante a elaboração do processo de criação em dança nas experiências estéticas. Os depoimentos do diário de bordo das professoras colaboradoras estão aqui transcritos conforme o original fornecido por elas. 


\section{Cena I}

\section{"Universo imagético"}

Compõe-se a cena a partir do som do espaço da escola, e os dançantes entram em cena, dançando fragmentos da sua matriz de movimento, criando formas. Simultaneamente é projetado um vídeo interativo do universo imagético (Anexo 1) das dançantes, construindo diálogos com os espaços que as imagens ocupam no mundo contemporâneo e com os corpos em cena. (Figuras 47 e 48).

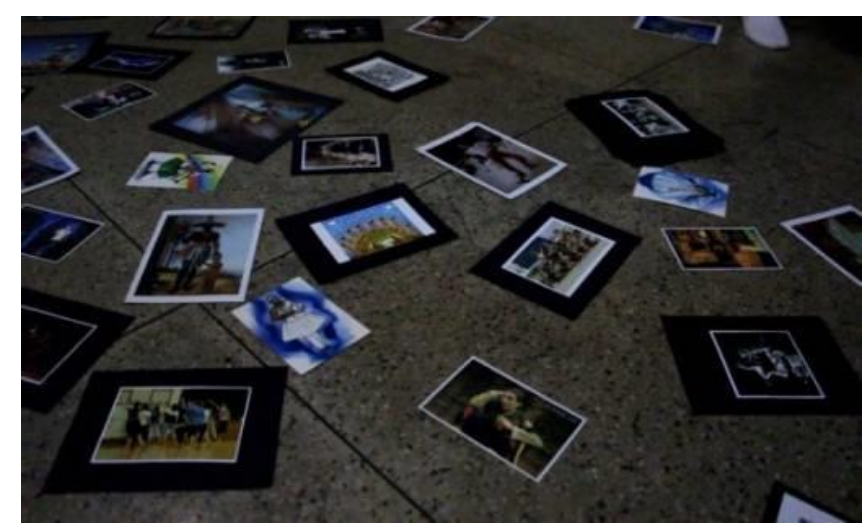

Figura 46: Universo imagético Fonte: Váriadas fontes.

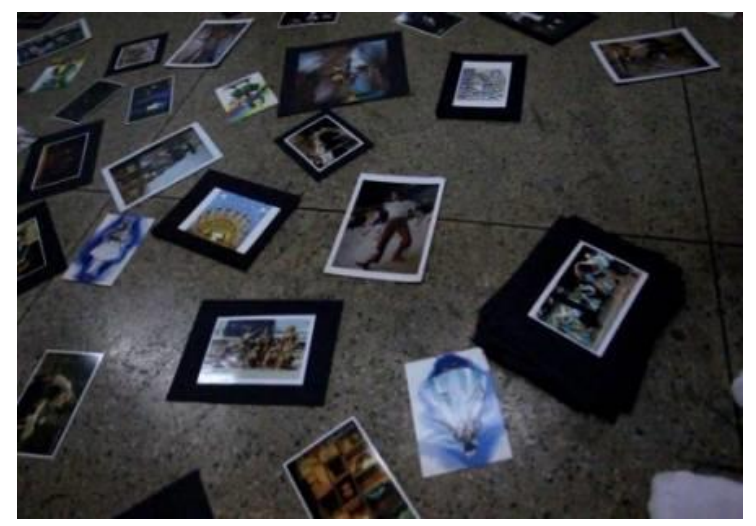

Figura 47: Universo imagético Fonte: Váriadas fontes.

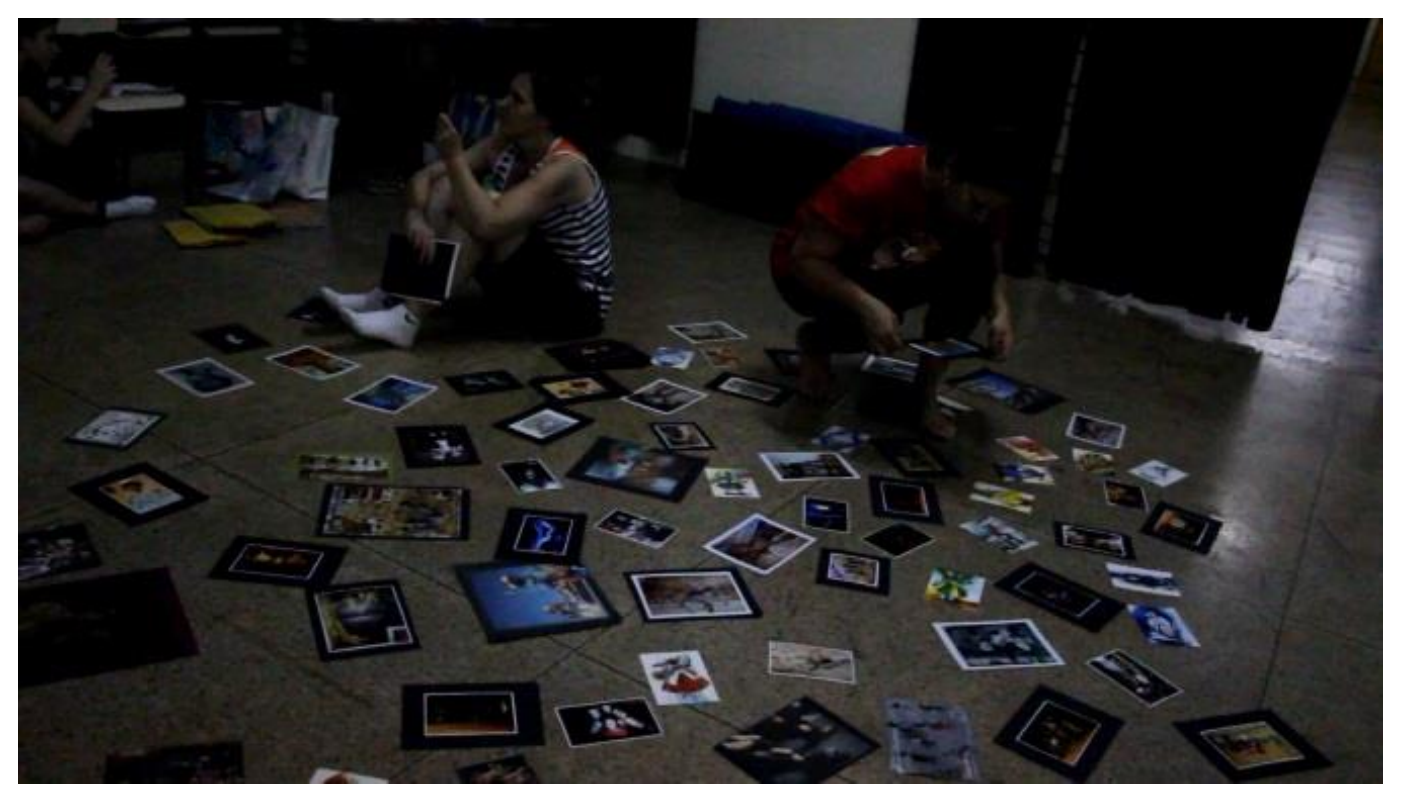

Figura 48: Universo imagético Fonte: Variadas fontes. 


\title{
Cena II
}

\section{"Singulares"}

Denominamos "Singulares" cenas individuais em que cada dançante entra em cena com sua matriz de movimento, compondo uma cena única e autoral, inspirada em suas narrativas visuais (Figuras 49 a 53). São cenas de uma matriz que está sujeita a se transformar no decorrer do processo das experiências estéticas. Suas narrativas orais são escolhas de diferentes olhares, vistas por diferentes ângulos, como argumenta Alice Fátima Martins (2008, p.99):

\begin{abstract}
Afinal, imagens, concepções estéticas e obras de arte não são neutras, inocentes, mas integram as redes de tensões inerentes às relações de poder das estruturas sociais em que são realizadas, circulam, e articulam sentidos. Desse modo, a eleição de certas imagens, concepções estéticas e obras de arte para integrarem os conteúdos veiculados à educação escolar, resulta da interação de diversos fatores, por trás dos quais prevalecem interesses os mais diversos, econômico, político dentre outros.
\end{abstract}

São escolhas pessoais que cada dançante manifesta a partir das relações e dos diálogos com sua história de vida. A cena dialoga com o vídeo e, simultaneamente, com a imagem do dançante e com sua narrativa oral, e é transcrita a cena individual de cada dançante interagindo com sua matriz de movimento. Isso ocorre em vários espaços, fazendo um jogo com as imagens escolhidas, ao som da oralidade das narrativas individuais de cada dançante.
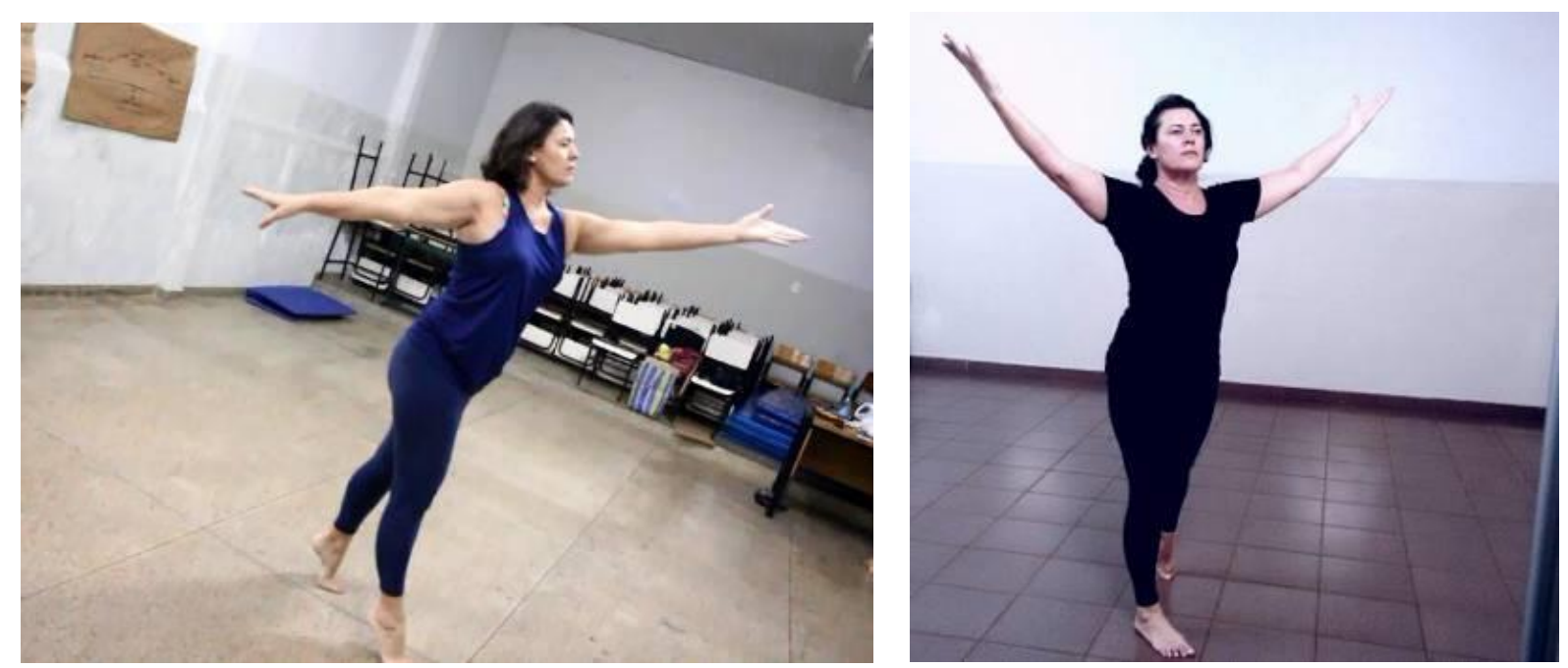

Figura 49: Composição da matriz (1) Fonte: Integrantes do grupo 


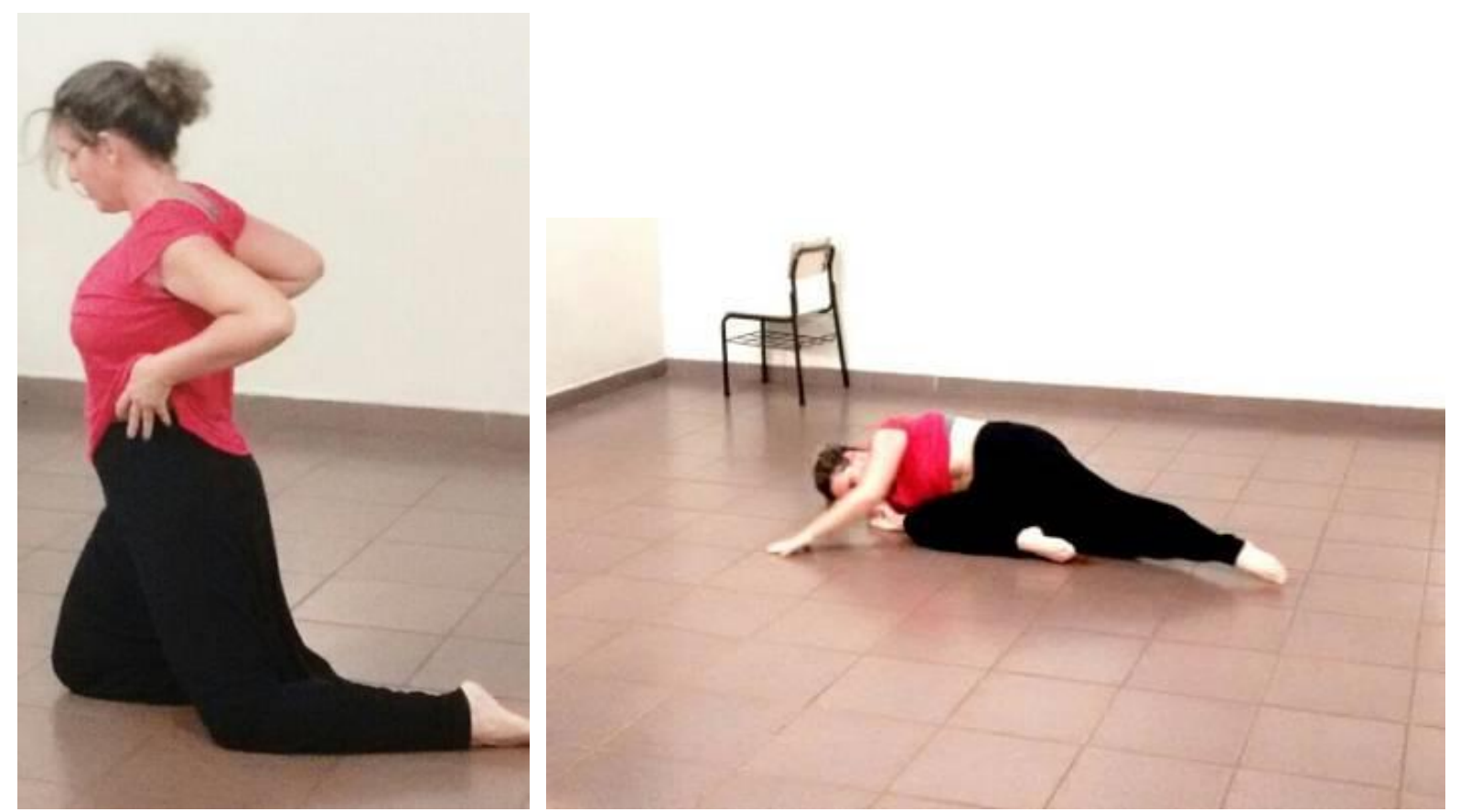

Figura 50: Composição da matriz (2)

Fonte: Integrantes do grupo
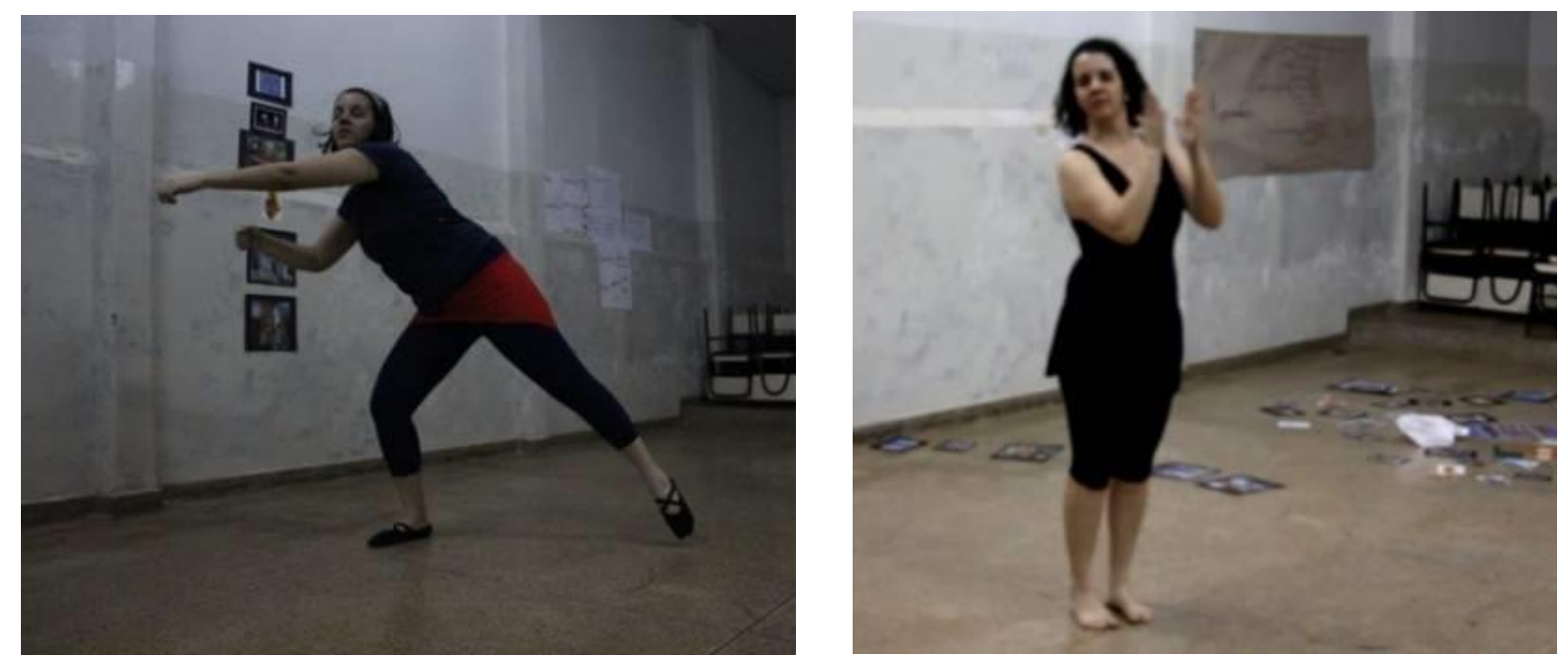

Figura 51: Composição da matriz (3)

Fonte: Integrantes do grupo

Observação da professora colaboradora Mônia (Figura 51) quanto ao olhar das matrizes:

Nas composições das matrizes das outras colegas eu estava sempre observando e tentando também fazer uma ligação com as figuras delas, também tive que registrar o meu ponto de vista através de uma câmera fotográfica, onde registrei no meu olhar através das fotos tiradas por mim de cada matriz feitas pelas outras professoras. Depois das fotos tiradas voltei a ver as imagens que tirei e o ponto de vista que tive naquele momento. Gostei muito chegou a influenciar na minha matriz, como também as fotos tiradas da minha matriz por elas. Tem fotos que registraram detalhes que não percebia antes. (Diário de bordo, 2015) 


\section{Outra observação da professora:}

Cada uma entra com sua matriz individual, entra em cena e sai para outra entrar e assim por diante. Interessante que, mesmo individual, a gente fica ligada à outra e as imagens não saem da cabeça, estão sempre presentes, a sequência delas o significado que elas me passam naquele momento. (Diário de bordo, 2015)
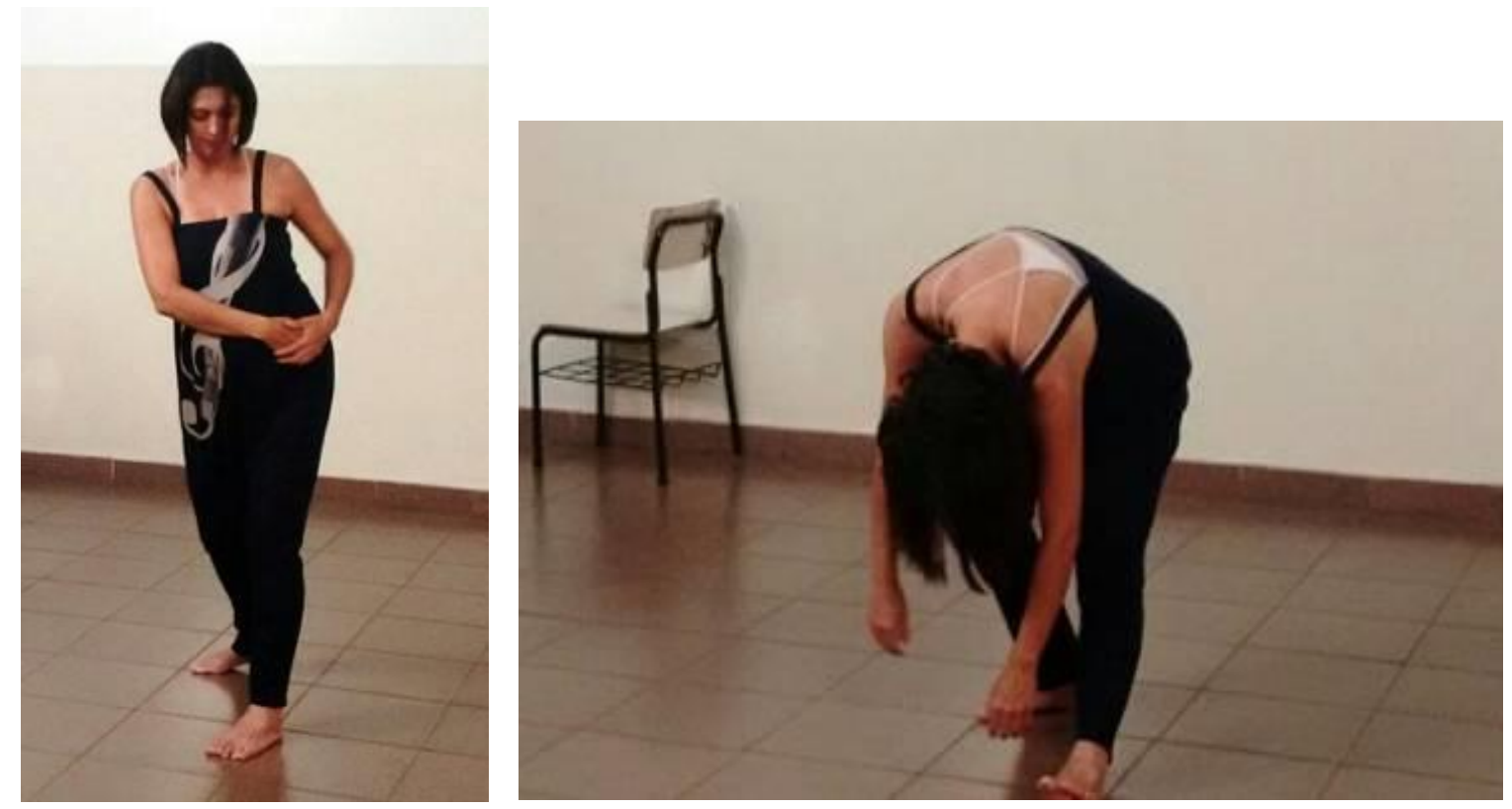

Figura 52: Composição da matriz (4)

Fonte: Integrantes do grupo
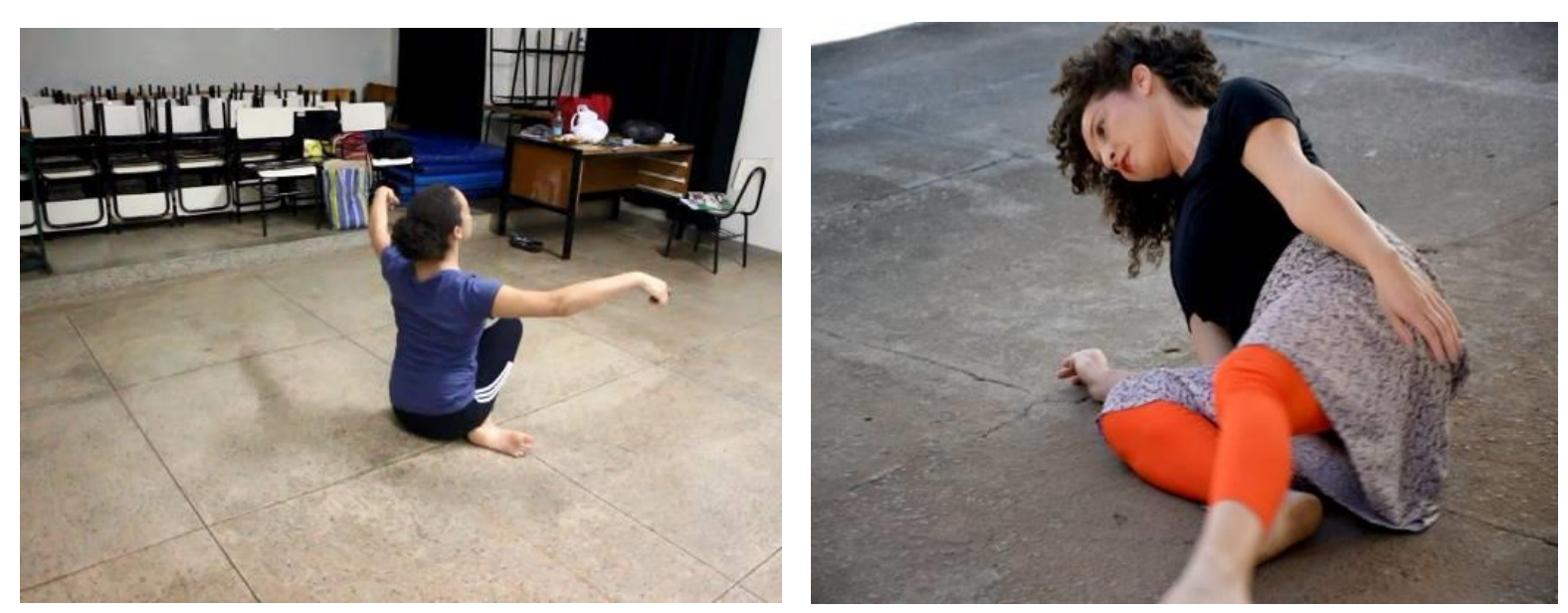

Figura 53: Composição da matriz (5)

Fonte: Integrantes do grupo 


\section{Cena III}

\section{"Diálogos Corporais"}

Todas entram em cena nos diálogos corporais, com o foco na construção de duas formas dos movimentos da composição da matriz. O jogo do olhar e da forma flui com respostas rápidas, sem uma construção mental anterior no decorrer dos encontros. Os diálogos ocorrem no encontro das dançantes. Ao elaborar duas formas da composição da matriz de movimento, uma em frente à outra, se olham e uma acompanha o movimento da outra, ora uma, ora outra fazendo a interação das suas formas. Ao compor os movimentos da matriz para cena, ocupam os espaços: reduzem, ampliam as formas nos níveis baixo, médio ou alto.

Os jogos corporais contribuem para o aumento da percepção corporal e para o desenvolvimento da parte motora, colaboram para desenvolver a rapidez de raciocínio, encontrar soluções rápidas para as situações que se apresentam. Pensamento e ação acontecem em um tempo rápido, fazendo que as perguntas sejam desenvolvidas instantaneamente, e a reação seja imediata. A composição instantânea se efetiva, ao comporem diálogos com dois encontros com duas dançantes, com as duplas interagindo simultaneamente (Figuras 54 a 58). É o sinal de seguir para a cena III.

A cena se constrói na interação com o vídeo simultaneamente, projetado com cenas que ocorrem em sala de aula na elaboração dos diálogos corporais no jogo da forma e do olhar do outro entre as duplas e ou trios. Há música que dialoga com a cena.

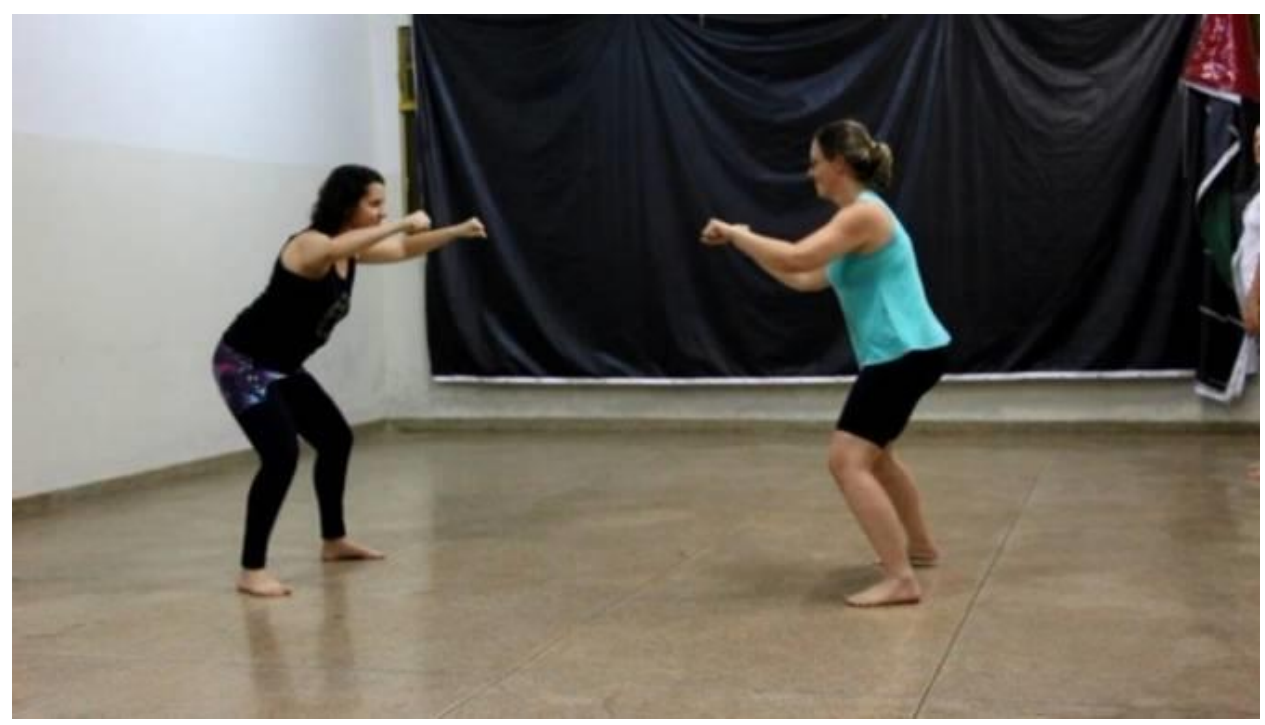

Figura 54: Diálogos corporais (1) Fonte: Integrantes do grupo. 


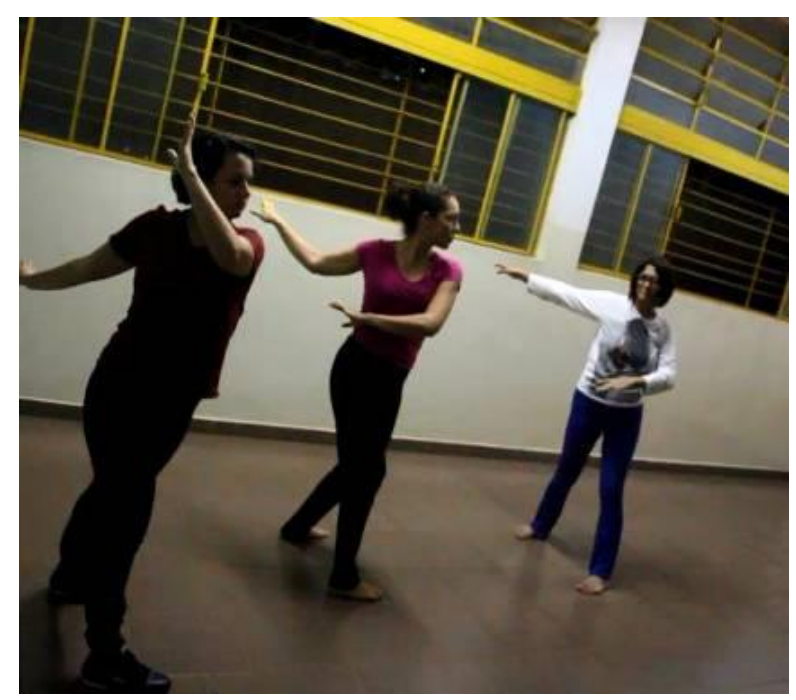

Figura 55: Diálogos corporais (2) Fonte: Integrantes do grupo

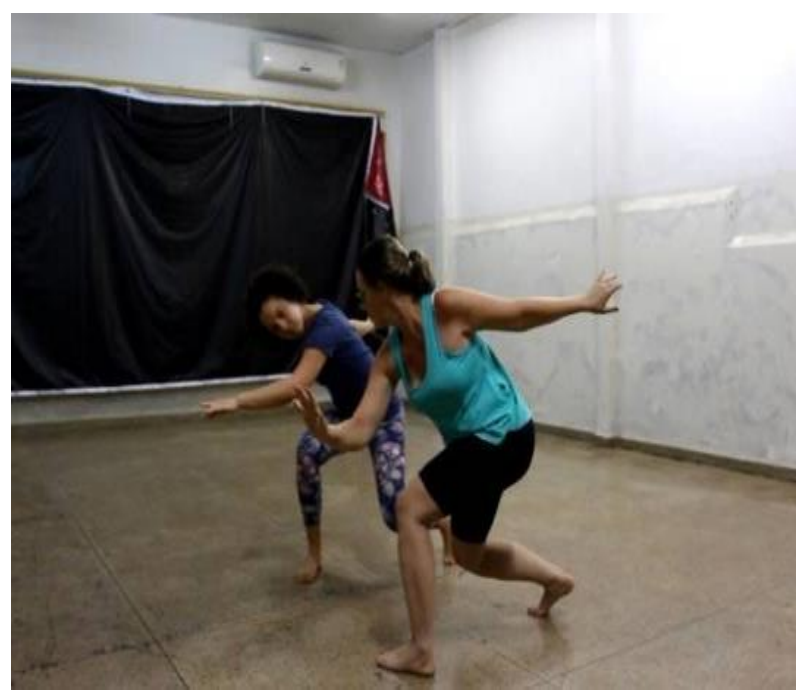

Figura 57: Diálogos corporais (4) Fonte: Integrantes do grupo

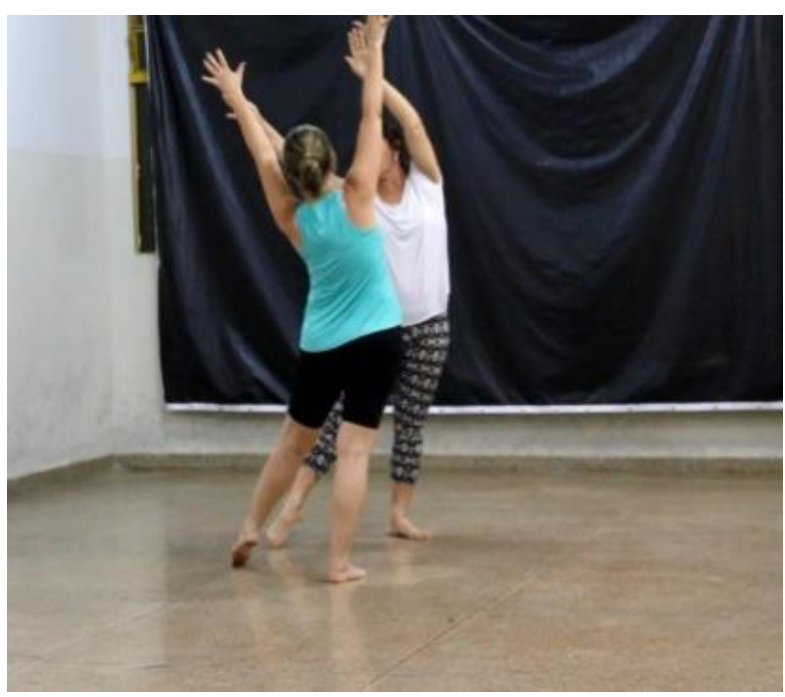

Figura 56: Diálogos corporais (3) Fonte: Integrantes do grupo

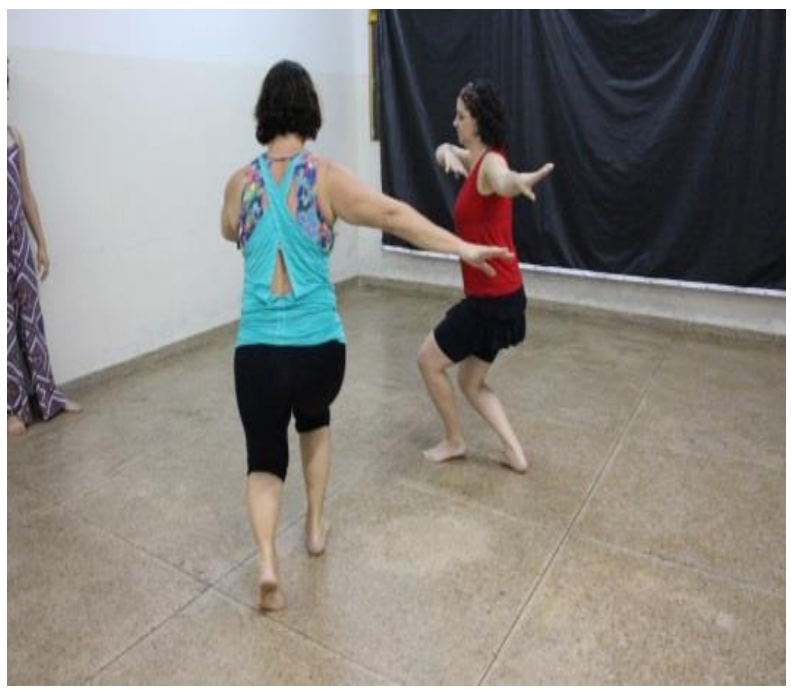

Figura 58: Diálogos corporais (5) Fonte: Integrantes do grupo

A professora colaboradora Mônia assim observa: "A proposta de trabalhar com jogos corporais é bem motivante, trabalhar o diálogo com o outro com o corpo e as matrizes criadas. Será encontro e diálogo com corpos diferentes, mas prontos para chegar a um resultado" (Diário de bordo, 2015). 


\section{Cena IV \\ "Conexões rizomáticas"}

Desnaturalizar o olhar, fazer o olhar estrangeiro olhar aquilo que não tenha percebido, olhar problematizado. O corpo inteiro olha o espaço e como ele penetra no seu corpo. Com isso, desaprender nossas amarras. A experiência de se sentir presente no mundo contemporâneo.

Todos os dançantes se põem em cena, fazendo conexões do jogo da sombra: uma segue a outra, utilizando fragmentos da composição da matriz e vice-versa. "Conexões rizomáticas" é o jogo que torna ágil quem o pratica, com respostas rápidas aos estímulos apresentados. É preciso estar receptivo a todos os estímulos e agir espontaneamente. Todos os sentidos são aguçados, e o corpo deve ficar em estado de alerta permanente. Ao propor o movimento, deve dialogar, ampliar as formas, reduzi-las e também mudar a dinâmica do movimento: tempo, fluência, espaço e força. As experiências estéticas vão se transformando, desdobrando em cenas a todo o momento da interpretação, na reconstrução delas. A marcação da composição instantânea passa por duas duplas e segue para cena V. A cena é acompanhada simultaneamente com vídeo, dialogando com as várias outras que ocorrem em sala de aula na elaboração do jogo da sombra, interagindo com a música. (Figuras 59 a 61).

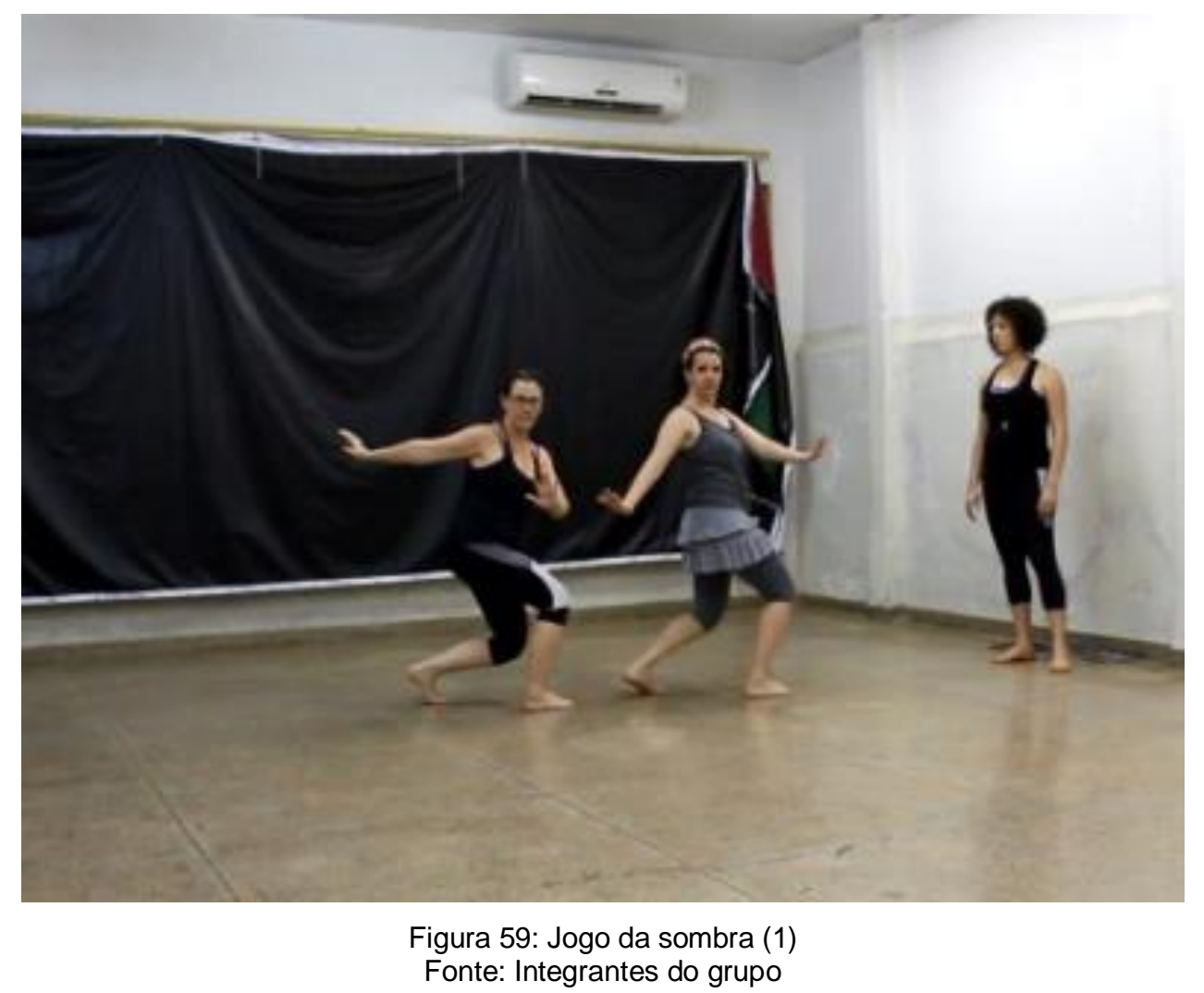




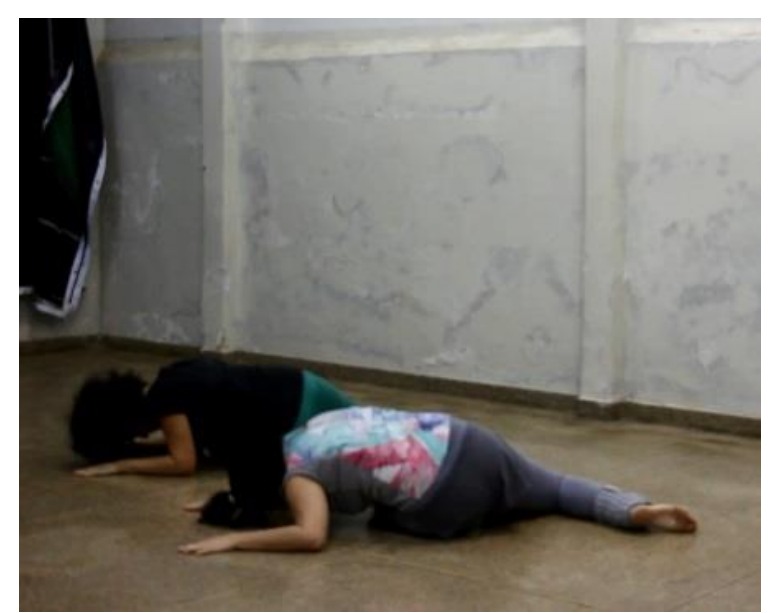

Figura 60: Jogo da sombra (2) Fonte: Integrantes do grupo

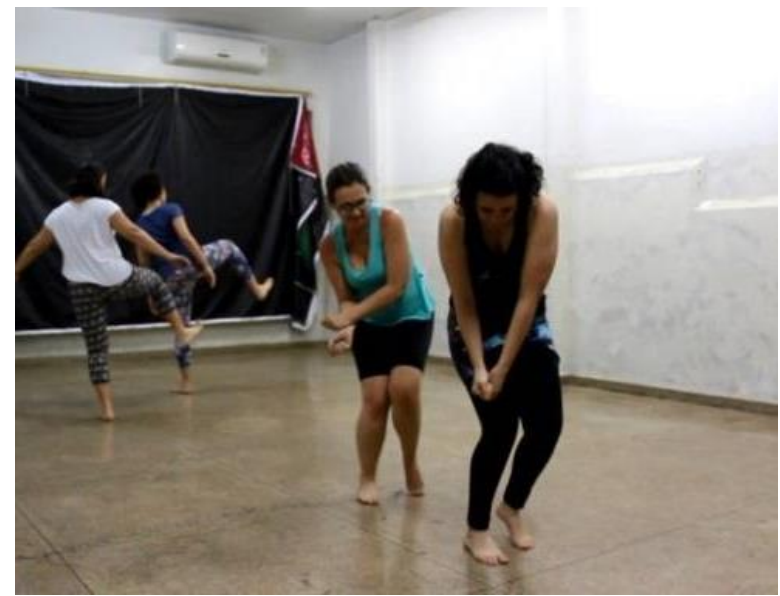

Figura 61: Jogo da sombra (3) Fonte: Integrantes do grupo

\section{Cena V}

\section{"Poéticas dos diálogos composicionais"}

Todas em cena. O jogo do espelho em duplas e/ou trios simultaneamente. A dançante em frente a outra, para socializar as células de movimento que compõem a matriz, construindo diálogos nas composições. A proposta é aproximar-se, distanciar-se do foco, em contraste de níveis, de formas e dinâmicas dos movimentos; dialogando o perto/o longe; o grande/o pequeno; movimentos rápidos/lentos; a dinâmica do movimento com seus desdobramentos composicionais. Passando por duas dançantes simultaneamente nos duos e/ou nos trios. Seguindo para cena VI. A cena é acompanhada simultaneamente por um vídeo, dialogando com várias cenas que ocorrem em sala de aula, na elaboração do jogo do espelho, interagindo com a música.

Afirma Ramos (2007, p.50): "Os Jogos Corporais, ao proporcionarem relacionamento entre corpos, ajudam na percepção da tridimensionalidade, da relação, do olhar a distância, do olhar mais perto, além de ajudar na afirmação da individualidade". Com isso, a investigação vem afirmar a relação dialógica que se dá, partindo do individual para o coletivo, na relação das poéticas dos diálogos composicionais de ver e ser visto. (Figuras 62 a 64) 

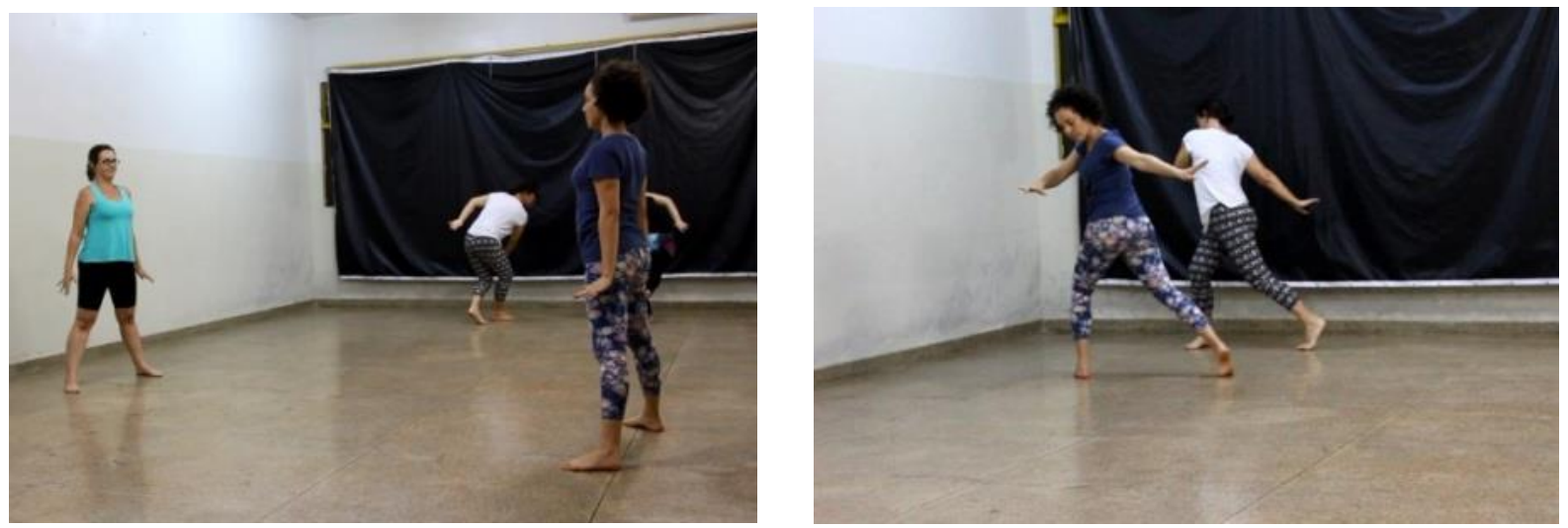

Figura 62: Jogo do espelho (1)

Fonte: Integrantes do grupo

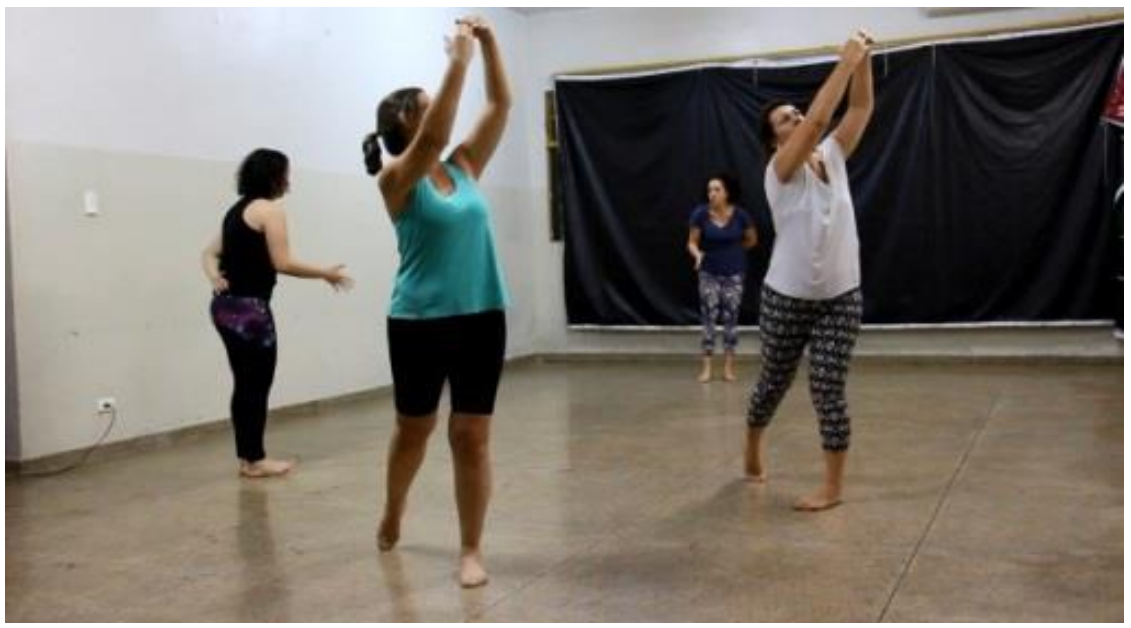

Figura 63: Jogo do espelho (2)

Fonte: Integrantes do grupo

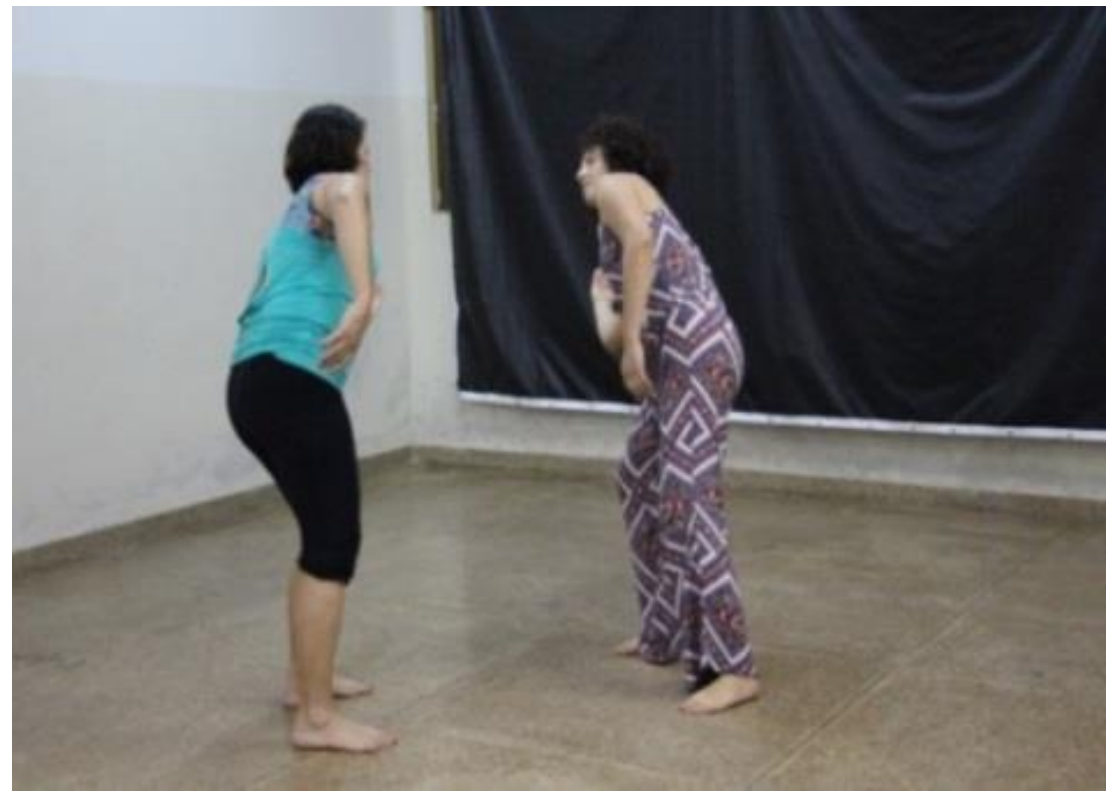

Figura 64: Jogo do espelho (3)

Fonte: Integrantes do grupo 


\section{Cena VI \\ "Desdobramentos composicionais"}

Agora o jogo segue o mestre. Todas em cena, e a locomoção no espaço são feita em relação a um foco nas diagonais. Todos seguem a composição da matriz do primeiro à frente do grupo, simultaneamente. Como afirma Ramos (2007, p.51), quando:

[...] se trabalha 0 ato da locomoção, os jogos giram em torno da movimentação de cada um dos participantes, da descoberta desta de um lugar para outro, da percepção de como mudar o grau e a sensibilidade do movimento, de como se relacionar e combinar os deslocamentos pelo espaço com o de um ou vários parceiros. Os Jogos Corporais conferem ao sujeito a plena consciência de seus espaços - o pessoal e o da sala de aula, com base na presença do outro.

O jogo dá liberdade para os desdobramentos da matriz: ela se transforma, modifica-se, vai se diluindo, ao criar e recriar os seus repertórios de movimentos. Explorando os espaços, os níveis, as formas, os planos e as dinâmicas, de acordo com as poéticas de cada dançante. A cena é acompanhada simultaneamente com vídeo, dialogando com várias cenas que ocorrem em sala de aula. Na elaboração do jogo, segue-se o mestre, passando por todas em cena, interagindo com as composições e as imagens, interagindo com música, sem marcação de tempo (Figuras 65 a 68).

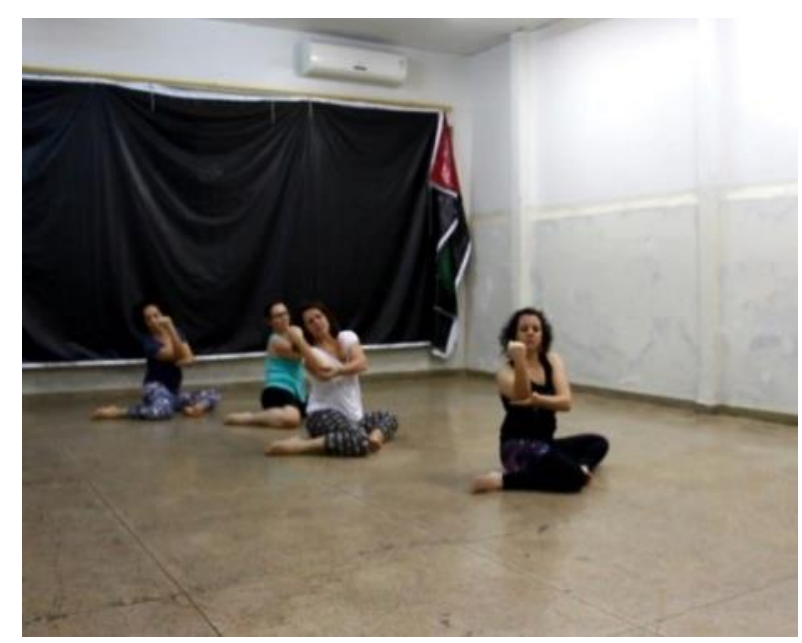

Figura 65: Jogo Segue o mestre (1) Fonte: Integrantes do grupo

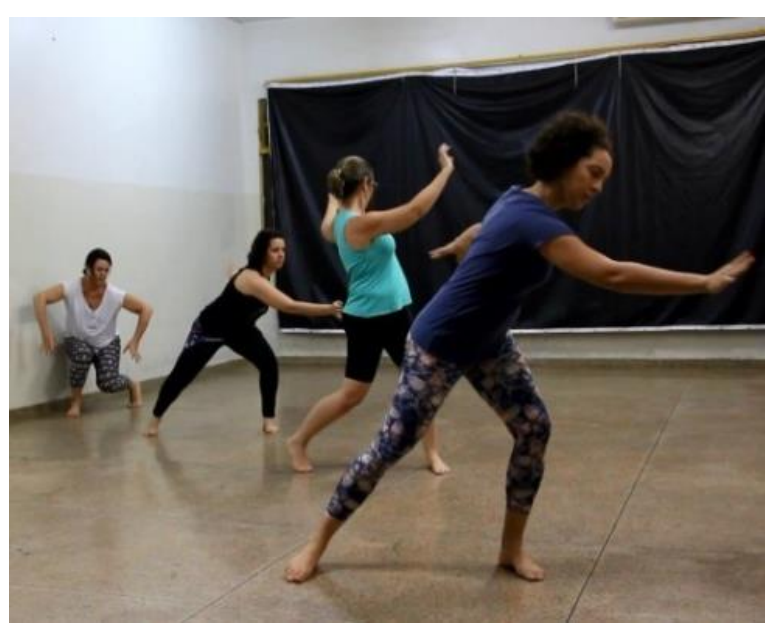

Figura 66: Jogo Segue o mestre (2) Fonte: Integrantes do grupo 
A professora colaboradora Cláudia relata sobre sua experiência nos efeitos dos jogos corporais na cena:

Com maior apropriação das células coreográficas construídas processualmente até aqui. Fomos motivadas investir mais no compartilhamento das mesmas, para isso, realizamos diversas ações: jogos, forma, sombra, espelho e segue o Mestre. Dessas experiências gostei, especialmente de perceber como as qualidades do movimento podem ser alteradas e transformadas na relação com o outro. (Diário de bordo, 2015) (Figuras 67 e 68)

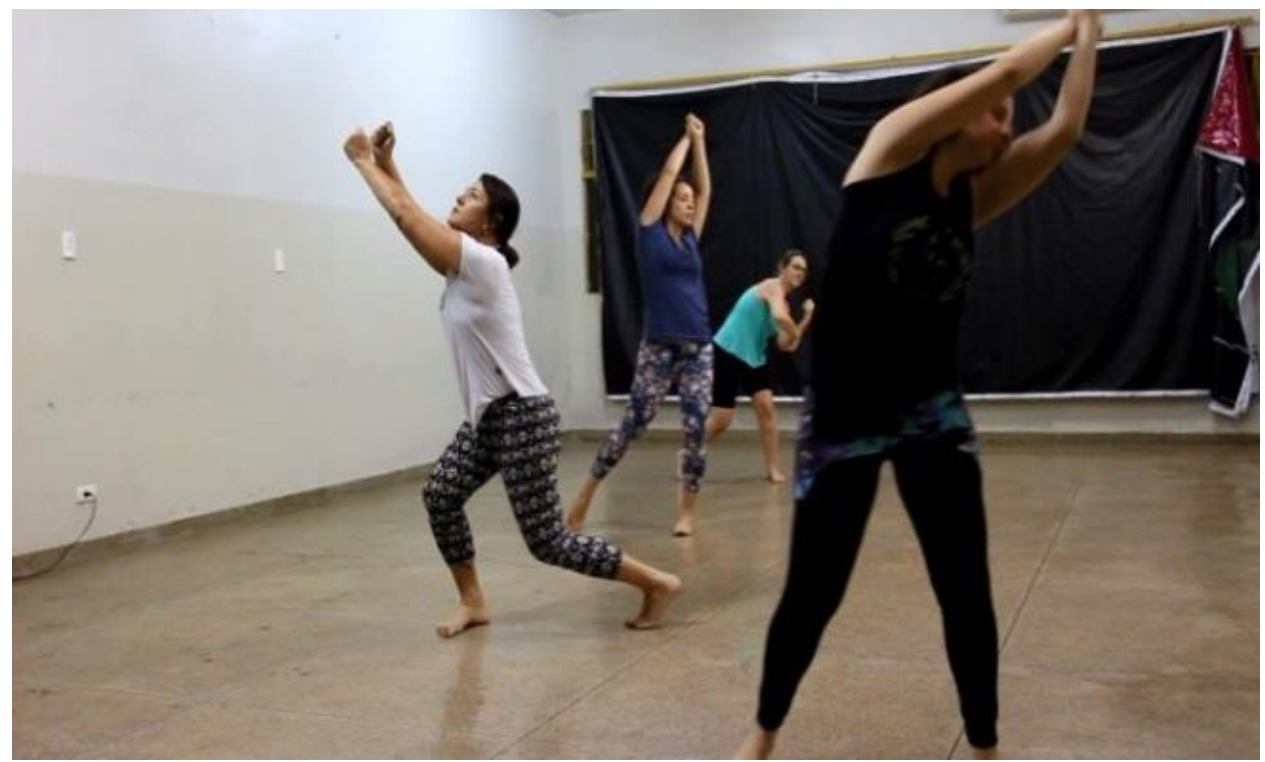

Figura 67: Jogo Segue o mestre (3)

Fonte: Integrantes do grupo

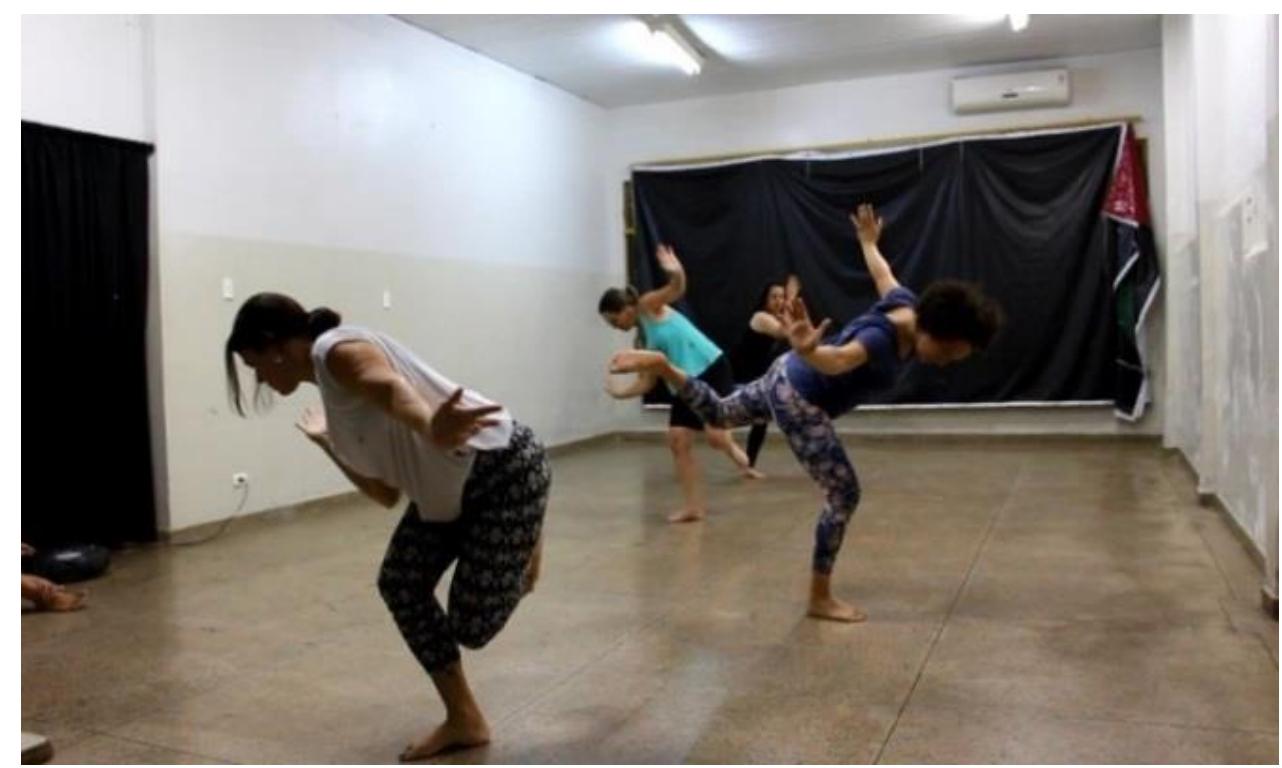

Figura 68: Jogo Segue o mestre (4)

Fonte: Integrantes do grupo

Cena VII 


\section{"Individuais/ simultâneas"}

Retomar a composição de matriz inicial com todas as dançantes em cena simultaneamente. A cena propõe construir diálogos com os jogos anteriores, ao compor a sua matriz de movimento, em que ela se desdobra, se transforma, se modifica, recria e reelabora, vai se diluindo no espaço e criam-se poéticas do olhar para cena. São possibilidades de vivenciar outras experiências estéticas de dança. Comenta Angel Vianna (apud RAMOS, 2007, p.50):

Daí sua importância do trabalho do ator, que deve, a cada dia, recriar sua interpretação para que a atuação não se cristalize e perca a capacidade espontânea de comunicar. Teatro é comunicação e, quanto melhor o ator o fizer, melhor será o seu trabalho na cana.

É o ato de revelar poéticas da ação cênica nas relações de estar presente o corpo na cena, vivenciar experiências estéticas, com múltiplos olhares para a cena.

A cena é acompanhada simultaneamente com vídeo onde são transcritas cenas individuais de cada dançante com sua matriz, com seus desdobramentos, explorando e percorrendo os vários espaços, até todas concluírem sua composição, interagindo com música sem um tempo marcado. Segundo o relato da professora colaboradora Cláudia sobre a cena 7 , a pesquisadora assim orientou:

[...] ao desenvolvermos ou melhor, realizarmos a cena 7, não ficássemos presas exclusivamente à própria sequência. Que o desdobramento proposto nas cenas anteriores "contaminasse" a nossa própria sequência. Me lancei nesse desafio e experimentei a improvisação de maneira bem significativa. (Figuras 69 a 71)

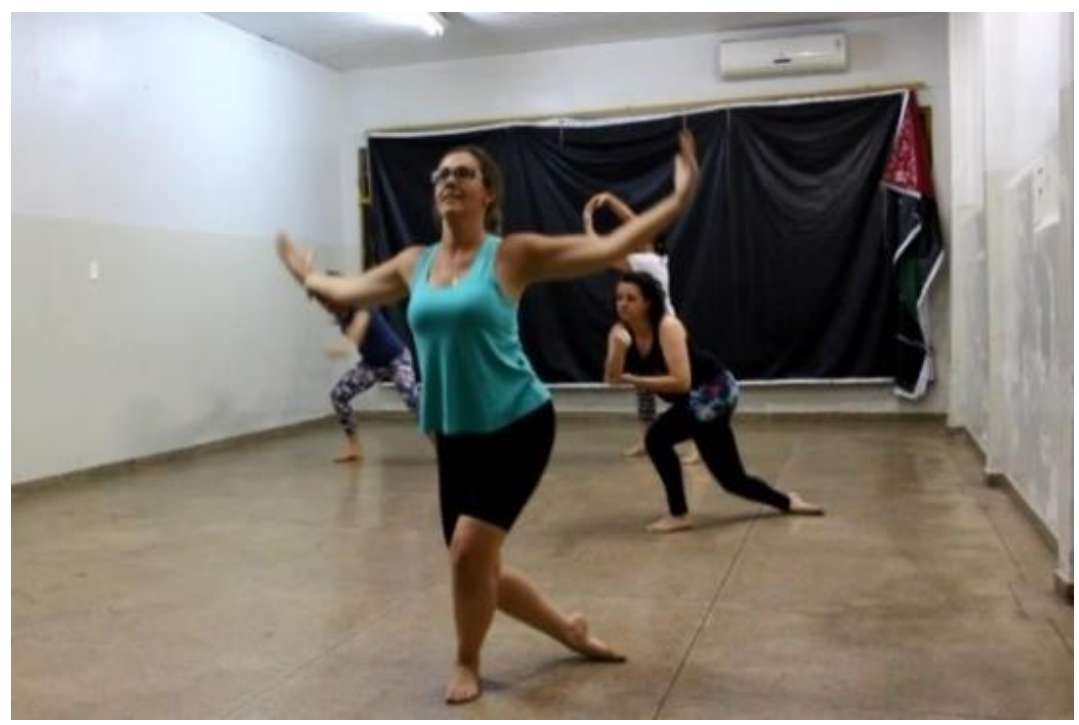

Figura 69: Individuais simultâneas (1) Fonte: Integrantes do grupo 


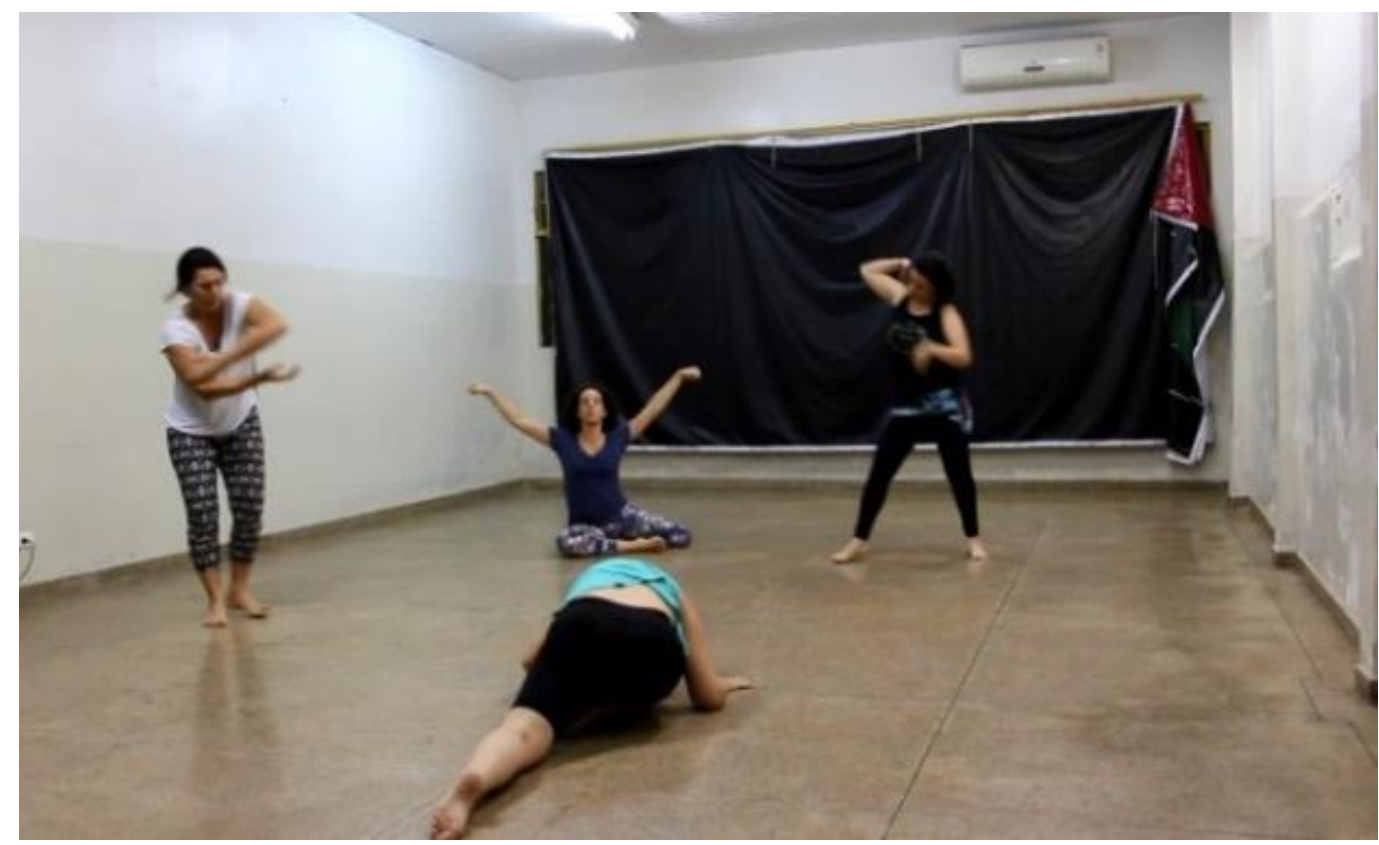

Figura 70: Individuais simultâneas (2) Fonte: Integrantes do grupo

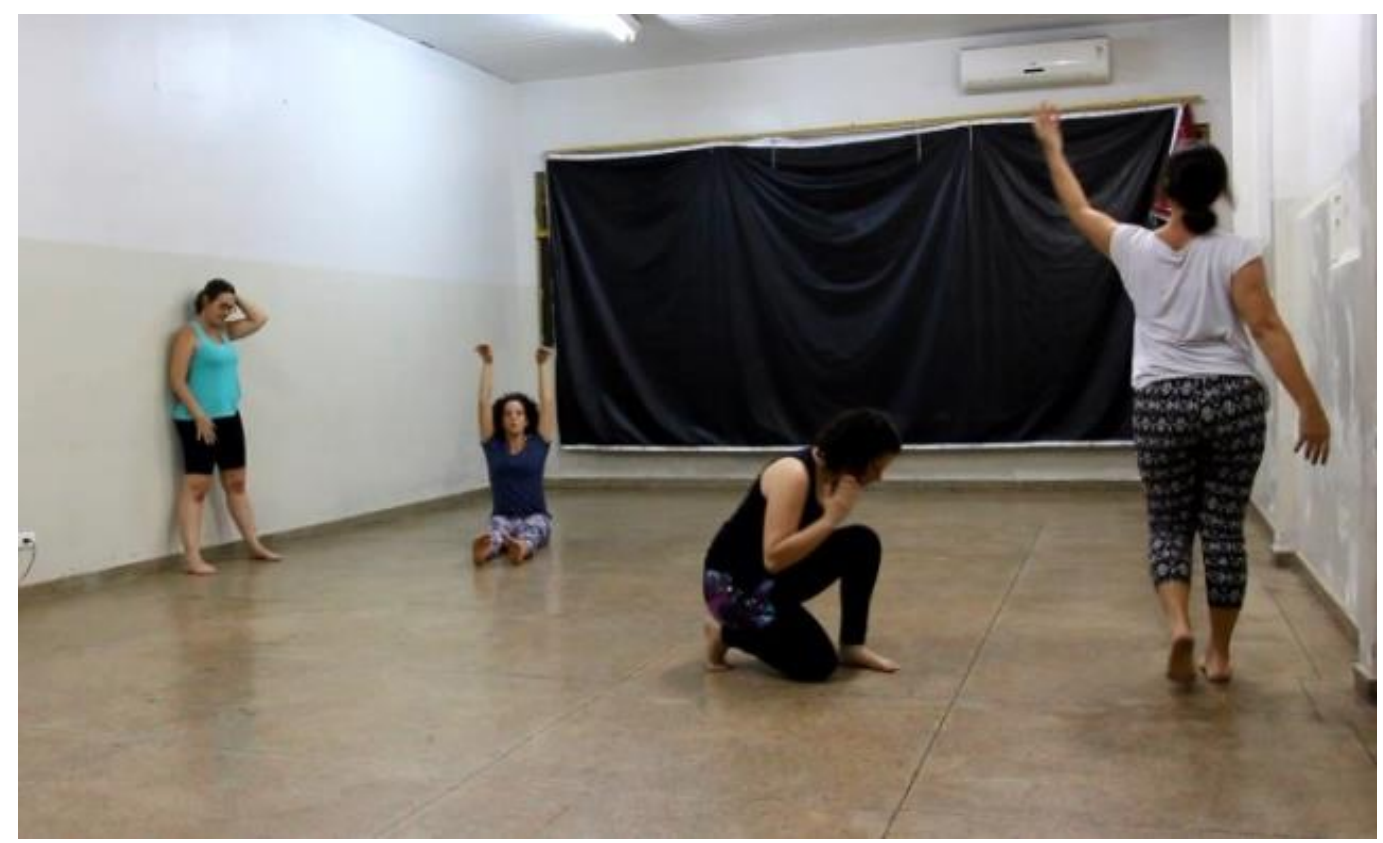

Figura 71: Individuais simultâneas (3)

Fonte: Integrantes do grupo 
Essa investigação partiu das nossas inquietações no percurso do ensino de dança no espaço escolar. Agora estamos prestes a concluir, porém não terminou, pois outros caminhos se abriram para a pesquisadora, instigaram-na a querer saber mais sobre inúmeras problemáticas.

Compartilhando essa investigação com as professoras colaboradoras da pratica educativa em dança, percebemos que precisamos não só ocupar espaços com nossa docência, mas sistematizar nossas experiências. Só com a memória, as lembranças e apenas o fazer, o trabalho fica raso, sem fundamentação teórica. Foi a partir das dificuldades que enfrentamos com alguns dados e informações do diário de bordo no percurso da investigação que identificamos, nos relatos dessas professoras colaboradoras, as suas limitações e problemáticas quanto à práxis em sala de aula.

Tentamos estimular, usando alternativas, promovendo ruptura do modo de ser visto como próprio sujeito, usando elementos que se encontram na prática para a linguagem escrita. Algumas alunas, com simplicidade, contribuíram e estão contribuindo. Com outras nos deparamos com os limites na escrita dos dados no diário de bordo. Obtivemos dados através das narrativas orais, um pouco no diário de bordo e na produção "Poéticas do corpo em cena" dos professores colaboradores.

Esperamos que compartilhar todo o processo com o grupo e para o grupo, numa ação dialógica, tenha gerado impactos, repercussões e desdobramentos nas suas práticas para o ensino de dança. Alguns relatos das professoras colaboradoras - como este, de Ana Paula - fazem referência ao trabalho do grupo:

Os encontros com o grupo foram ricos em troca de experiências corporais, profissionais e coletivas onde foram abordados temas importantes para pensar como o corpo na dança pode ser interpretado, utilizado, cuidado, disciplinado, sentido de várias maneiras nas culturas e épocas. Corporalmente experimentamos o mundo escrevendo a nossa história. (Diário de bordo, 2016)

A referida professora faz suas relações de troca de experiências profissionais e coletivas, abordando a importância de pensar o corpo na dança como um sujeito do processo, construindo a história das suas relações com a cultura. 
A professora colaboradora Mônia aborda suas inquietações em relação aos encontros e ao que reverberou das imagens:

O que achei... Gostei dos encontros e como aconteceu. Trabalho com imagens foi interessante escolher e depois montar a matriz. Cada vez um desafio, mesmo mantendo a matriz, mas contava o nosso estado de espírito, de trabalho e como chegávamos no encontro tinham influência na matriz das imagens. O que senti... Como falei um pouco antes, depende do dia. Mas gostei de trabalhar com os jogos na composição final onde entravam as matrizes de todas e interagiam e ter os contatos com as duplas, trios e grupo. (Diário de bordo, 2016)

Já, para a professora colaboradora Itana, o processo criativo se deu nas escolhas:

\begin{abstract}
Várias imagens foram colocadas no espaço para escolhermos algumas que tiveram alguma lembrança, fossem significativas para nós, foi uma sensação boa, uma recordação e satisfação... escolhi imagens representativas [...] interior, família, e religiosidade, música, cores em relação a dança, experiências no trabalho: formas expressivas, remetem a palco, apresentação, espetáculo e ao mesmo tempo simplicidade nos movimentos. (Diário de bordo, 2016)
\end{abstract}

Assim comenta a professora colaboradora Cláudia, ao retomar os encontros esse ano:

[...] para as narrativas e escritas do diário de bordo decidi não mais só descrever os acontecimentos e procedimentos metodológicos desenvolvidos durante os encontros, mas buscar outras possibilidades de registro. Rememorando as experiências, destaco: o encontro entre professores de dança da rede e a disponibilidade de cada um para participação desse projeto de pesquisa; a possibilidade significativa de formação continuada que esses encontros proporcionaram; o desafio de conciliar interesses objetivos entre pesquisadora e singularidades dos "professores pesquisados"; a dança, as danças e seus deslocamentos nos corpos. Como ensinar arte/dança é complexo! Do percurso: escolher as imagens - justificar a escolha verbalmente - o que essas imagens reverberam no corpo-pesquisa de movimento - construir células coreográficas individuais, jogos e qualidades de movimentos. (Diário de bordo, 2016)

Partindo dos relatos das professoras colaboradoras, foi possível criar e recriar espaços constituídos por narrativas orais, corporais, imagéticas, gestuais; despertar linguagens adormecidas; ampliar olhares, escutas de movimentos sensíveis. Foram propostas referências estéticas durante o processo criativo da composição coreográfica e do mundo imagético, para compor uma ação cênica na criação de imagens, que resultaram em outro estudo sobre as imagens, criando e recriando um mundo imagético de poéticas do corpo em cena (Anexo II). 
Abrimos agora para as considerações quanto à prática educativa "Imagem em cena e o corpo que dança: poéticas pedagógicas": o que foi significativo no ensino de dança, que impactos gerou e suas repercussões. Assim a professora colaboradora Ana Paula relata:

O processo todo de desenvolvimento da pesquisa também auxiliou um pensar a prática pedagógica a partir das vivências experimentadas por mim, onde 0 individual se entrelaça ao coletivo, formando teias de conexões humanas em dança. Senti uma mudança no meu olhar sobre as individualidades dos alunos e os seus repertórios corporais, o que me ajudou a propor atividades bem mais próximas deles. É possível, num trabalho com a dança na escola, que uma metodologia diversificada garanta aos estudantes uma maior valorização da individualidade e criatividade, onde se possa ampliar o seu repertório de movimentos, individual e em grupo. (Diário de bordo, 2016)

Também a professora colaboradora Mônia afirma:

percebi que poderia trabalhar com meus alunos na escola onde trabalho com dança. Cheguei a usar os jogos e aí, percebendo que a cada aula que usei os jogos, os alunos iam melhorando e soltando. No nosso estudo também estava vendo que a cada encontro havia mais diálogos corporais. (Diário de bordo, 2016)

E a professora colaboradora Itana destaca:

De uma forma geral, a experiência desse processo vivido, experimentado foi de grande valia, desde o início...a convivência, os momentos etc... Ao escolher as imagens, veio logo a sensação (infância); a emoção (adolescência) e a satisfação (adulta) ...onde cada imagem foi pensada, estudada, relacionada aos movimentos corporais no qual foram escolhidos: dança, imagem e corpo. E com certeza foram experimentados com meus alunos, mesmo "especiais", foram momentos gratificantes. A emoção de vêlos vivenciando certos movimentos no limite de cada um ...não tem preço! (Diário de bordo, 2016)

Esses momentos na sala de aula são relevantes oportunidades de vivenciar a dança como experiência que se inscreve nos corpos dançantes. As proposições de sala de aula são experiências que vão se modificando e se transformando pelos seus pares, construindo relações de intérpretes criadoras, pois uma observa a outra, fazendo intervenções, numa relação dialógica. Concordamos com Miller (2014, p.103), ao dizer que "a experiência da sala de aula provoca o sujeito na sua totalidade em cada vivência. As reverberações das experiências acontecem não como acúmulo de informações, mas como vivências inscritas na pele com toda a gama de intensidade". 
Consideramos a sala de aula como laboratório de investigação, em que o acaso provoca um estado de presença e escuta desse corpo presente em experiência. A vivência de um acontecimento em comum no tempo e no espaço compartilhados com o grupo de pessoas constitui uma experiência em sala de aula que nos dá sentido e significado, é uma experiência singular e única. Larossa (2002, p.21) pensa a educação a partir da experiência/sentido. "A experiência é o que nos passa, o que nos acontece, o que nos toca. A cada dia se, passam muitas coisas, porém, ao mesmo tempo, quase nada acontece".

Assim, nos registros dos processos criativos dos intérpretes criadores, as ações cênicas vão se transformando e as experiências estéticas se ampliando e elaborando poéticas de movimento na cena. A partir delas se criaram e recriaram as cenas para a produção das "Poéticas do corpo em cena".

Em sala de aula foram fotografados e filmados, pelas professoras colaboradoras, fragmentos do processo, o que gerou uma exposição de 25 fotos de toda a criação e das experiências estéticas em dança (Anexo II).

Considerando que cada professora colaboradora fez sua avaliação, acreditamos que elas partiram de suas inquietações sobre o ensino e dos posicionamentos daquilo em que acreditam para o ensino de dança. Estas são as considerações finais da professora colaboradora Ana Paula:

Assim, acredito que essa pesquisa foi uma oportunidade que facilitou ao professor participante um repensar o ensino da dança no espaço da escola, tendo o propósito de trabalhá-la como conhecimento, oportunizando aos alunos vivências teórico-práticas, transformando a expressão pessoal dos indivíduos através do pensamento, da imaginação, da problematização e de ideias sobre e através da dança. (Diário de bordo, 2016)

Já a professora colaboradora Alice confessa:

[...] provocou em mim um diálogo e visão de mundo/arte enriquecedora e significativa. Minhas escolhas durante todo o trabalho possibilitaram um processo de criação e direção significativa na educação do sensível e no ensino da dança como diálogo artístico-cultural no contexto escolar.

E revela a professora colaboradora Cláudia:

[...] a necessidade do fazer artístico para o professor que ensina arte, que continua pesquisando, aprendendo e dançando é o que nos faz atuar de forma relevante com nossos estudantes. O nosso corpo adulto criando e poetizando nossa relação com a arte e a educação. (Diário de bordo, 2016) 
Muito desse processo criativo se transformou durante 0 percurso. Ao percorrer os caminhos da pesquisa, muitas dificuldades se apresentaram, assim como possibilidades se abriram, num campo vasto e pleno de significados e subjetivações. Esta é uma prática pedagógica que consideramos plena de abertura para diferentes práticas, novas produções interativas, visto ser um processo elaborado por subjetividades diversas, todas elas plenas de história, de desejos e de experiências que conformam a singularidade de cada um. Esta não significa, portanto, uma conclusão, mas o contemplar de um horizonte sempre aberto, para todos aqueles e aquelas que desejam construir os seus percursos a partir de seus próprios cenários. 
ARRUDA, Solange. Arte do movimento: as descobertas de Rudolf Laban na dança e ação humana. São Paulo: PW Gráficos e Editores Associados, 1988.

BERTAZZO, Ivaldo; BOGÉA, Inês. Espaço e corpo: guia de reeducação do movimento. São Paulo: SESC, 2004. p.7; p.16; p. 33; p. 70 e p. 118.

FARINA, Cynthia. Formação estética e estética da formação. In: FRITZEN, Celton; MOREIRA, Janine (Org.). Educação e Arte: as linguagens artísticas na formação humana. Campinas-SP: Papirus, 2008. p.101-102 .

FIORENTINI, Leda Maria Rangearo; CARNEIRO, Vânia Lúcia Quintão Carneiro. Tv na escola e os desafios de hoje: usos da televisão e do vídeo na escola. 2. ed. Brasília: Ed. Universidade de Brasília, 2002.

FREIRE, Paulo. Pedagogia da autonomia: saberes necessários à prática educativa. São Paulo: Paz e Terra, 1996. (Coleção Leitura).

HERNANDEZ, Fernando. Catadores da cultura visual: proposta para uma nova narrativa educacional. Tradução: Ana Duarte. Porto Alegre: Mediação, 2007.

LARROSA, Jorge. Tecnologia do eu e educação. In: SILVA, Tomaz T. (Org.). 0 sujeito da educação: estudos foulcaultianos. Petrópolis-RJ: Vozes, 1994. p.35-86.

. Notas sobre experiência e o saber de experiência. Revista Brasileira de Educação, Rio de Janeiro, n. 19, p.20-28, jan./abr. 2002.

LIMA, Eduardo C. Cidadania - A formação escolar pela dança. Entrevista com Marcia Strazzacappa. Dança em Revista, São Paulo, n. 7, p. 11, jun./ jul. 2007.

LOBO, Lenora; NAVAS, Cássia. Arte da composição: teatro do movimento. Brasília: LGE, 2008.

LUCKESI, Cipriano Carlos. Avaliação da aprendizagem escolar: um ato amoroso. São Paulo: Cortez, 1986.

MARQUES, Isabel. Movimento de reorientação curricular - Educação Artística, visão Aérea 2/7 dança. São Paulo: CONAE, 1992.

. Dançando na escola. São Paulo: Cortez, 2003.

MARQUES, Isabel; BRASIL, Fabio. A Arte em questões. São Paulo: Digitexto, 2012.

MARTINS, Alice de F. Conflitos e acordos de cooperação nos trânsitos das visualidades na educação escolar. In: MARTINS, Raimundo (Org.). Visualidade e educação. Goiânia: FUNAPE, 2008. p. 97-108. 
MARTINS, Raimundo. Imagem, identidade e escola. In: MENDONÇA, R. (Coord.). TV Escola/Salto para o futuro: cultura visual e escola. Ano XXI, Boletim 09, p.1521, ago. 2011a. Disponível em: http://tvbrasil.org.br/fotos/salto/series/14380009CulturaVisual.pdf>. Acesso em: 10 mar. 2016.

MARTINS, Raimundo. Pensando com imagens para compreender criticamente a experiência visual. In: ASSIS, Henrique L.; RODRIGUES, Edvânia B. T. (Org.). Educação das artes visuais na perspectiva da cultura visual: conceituações, problematizações e experiências. Goiânia: Kelps, 2011b. p. 19-38.

MEIRA, Marly R. Filosofia da criação: reflexões sobre o sentido do sensível. Porto Alegre: Mediação, 2003.

MILLER, Jussara. A escuta do corpo: sistematização da técnica Klauss Vianna. São Paulo: Summus, 2007.

O corpo presente: uma experiência sobre dança-educação. ETD- Educ. Temát. Digit., Campinas-SP, v. 16, n.1, p. 100-114, jan./abr. 2014. ISSN 1676-2592. Disponível <http:/www.fae.unicamp.br/revista/index.php/etd/article/view/6172>. Acesso em: 30 abr. 2015.

MOMMENSOHN, Maria. Corpo trans-lúcido: uma reflexão sobre a história do corpo em cena. In: MOMMENSOHN, Maria; PETRELLA, Paulo (Org.). Reflexões sobre Laban, o mestre do movimento. São Paulo: Summus, 2006. p.106.

MOTA, Julio. Rudolf Laban, a coreologia e os estudos coreológicos. Repertório, Salvador, n. 18, p. 63-64, 2012.

PELLEGRIN, Ana de. Ensino de dança: finalidade necessidade e identidade. In: SANTOS, Rosirene C.; RODRIGUES, Edvânia B. T. (Org.). 0 ensino de dança no mundo contemporâneo: definições, possibilidades e experiência. Goiânia-GO: Kelps, 2011. p. 33.

RAMOS, Enomar. Angel Vianna: a pedagogia do corpo. São Paulo: Summus, 2007.

RENGEL, Lenira. Dicionário Laban. São Paulo: Annablume, 2003.

Os temas de movimento de Rudolf Van Laban: modos de aplicação e referências I - II - III - IV - V - VI - VII e VIII. São Paulo: Annablume, 2008.

SANTOMÉ, Jurjo T. Globalização e interdisciplinaridade: currículo integrado. Tradução: Cláudia Schilling. Porto Alegre: Editora Artes Médicas Sul, 1998.

SILVA, Tomas T. Documento de identidade: introdução às teorias do currículo. Belo Horizonte: Autêntica, 2011.

STRAZZACAPPA, Marcia. Dança em revista- Capoeira ao som do birimbau. In: LIMA, Eduardo C.; Cidadania - A formação escolar- o papel da escola. Ano1, p.09, junho/ julho 2007. Disponível em :www.danceemrevista.com.br.

THIOLLENT, Michel, Metodologia da pesquisa-ação. São Paulo: Cortez, 2004. 
TOURINHO, Irene. As experiências do ver e ser visto na contemporaneidade: por que a escola deve lidar com isso? In: MENDONÇA, R. (Coord.). TV Escola/Salto para o futuro: cultura visual e escola. Ano XXI, Boletim 09, p. 9 -14, ago. 2011. Disponível em: http://tvbrasil.org.br/fotos/salto/series/14380009-CulturaVisual.pdf>. Acesso em: 10 mar. 2016. 
ANEXOS 
A N EXO 1

U NIVERSO I M A GÉTICO

* Não foi possível colher informação sobre as referências de algumas imagens que compõem esse trabalho porque foram colhidas, colecionadas, catalogadas ao longo de minha carreira como docente para desenvolver minhas aulas de dança. 

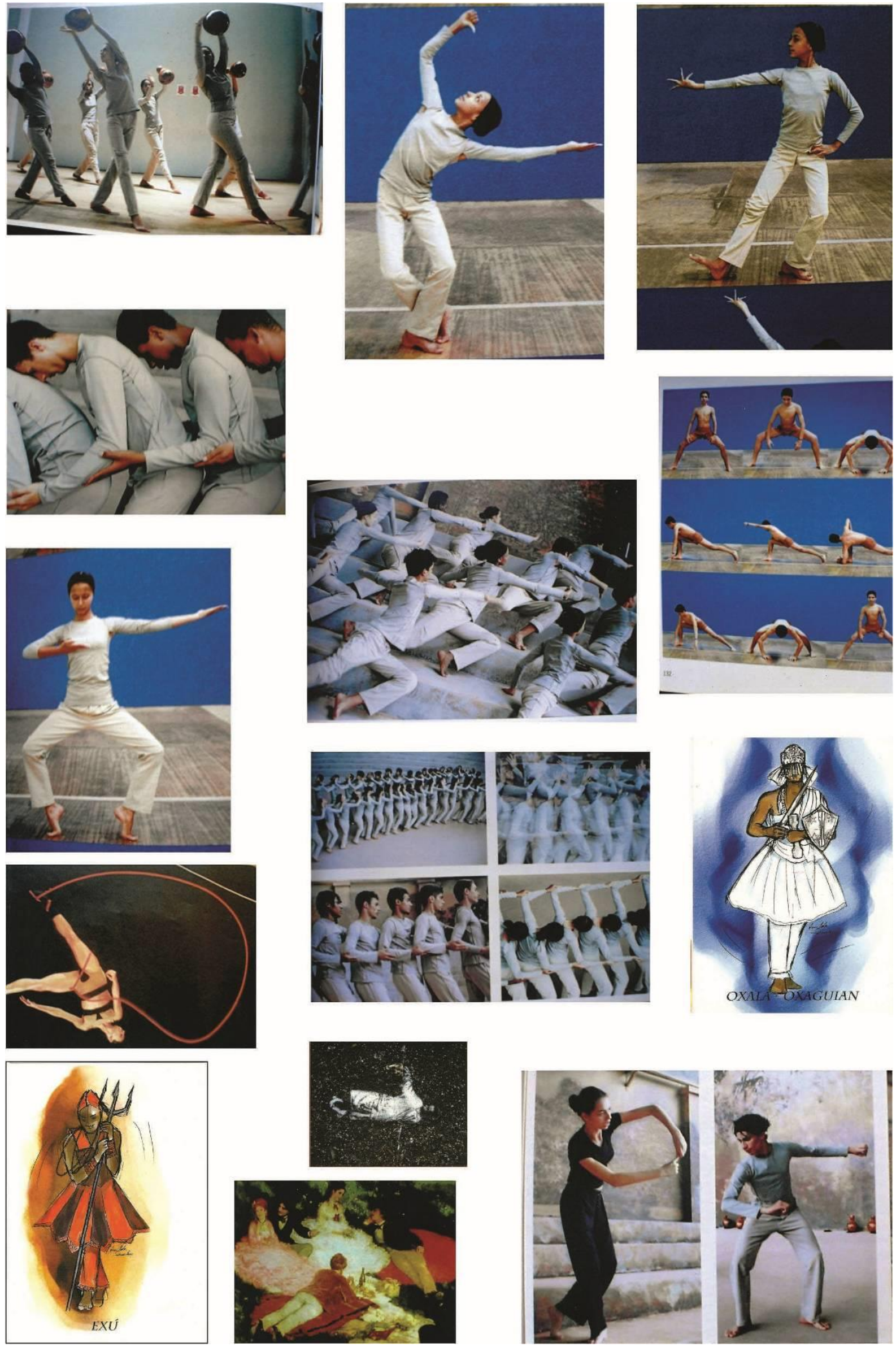

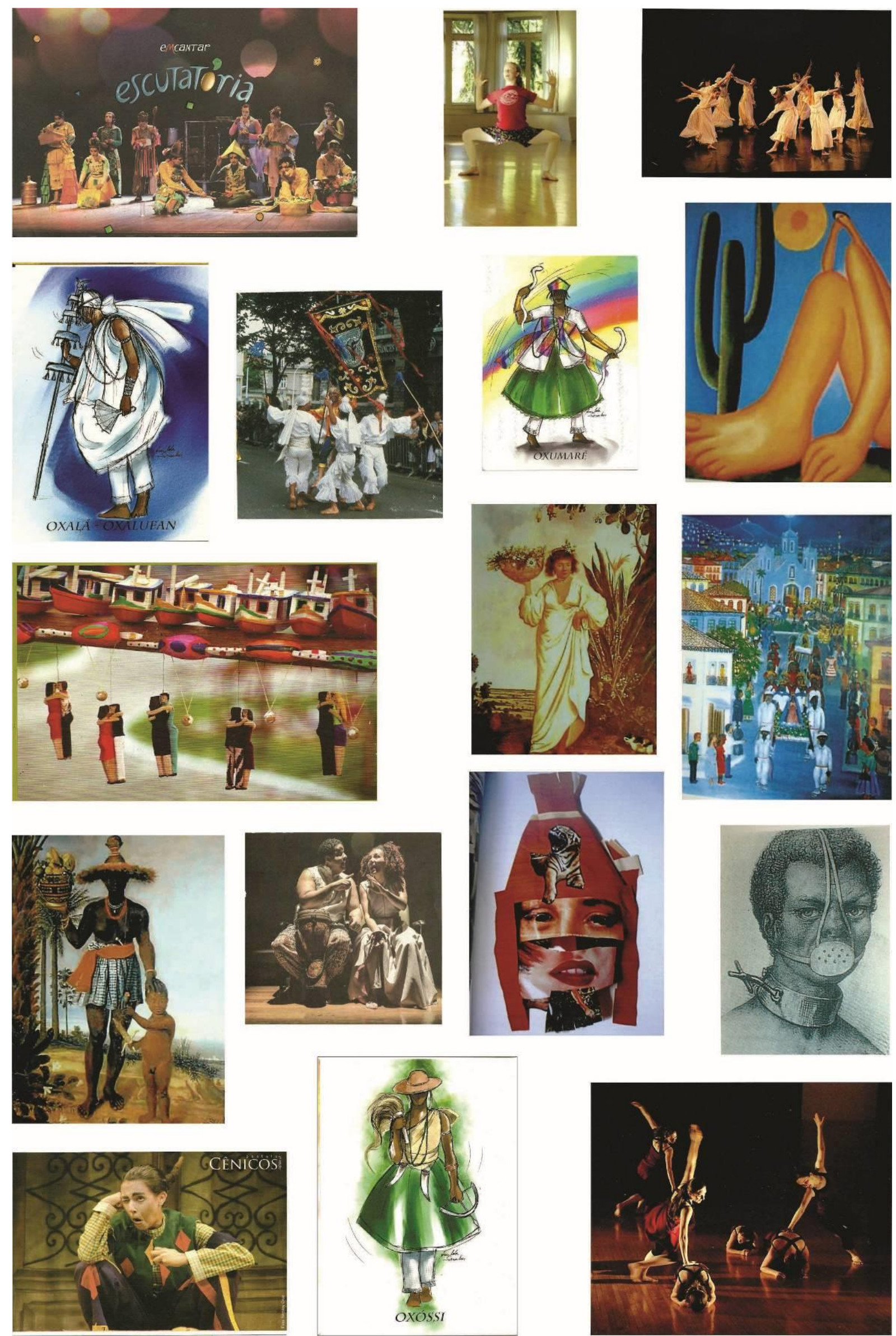

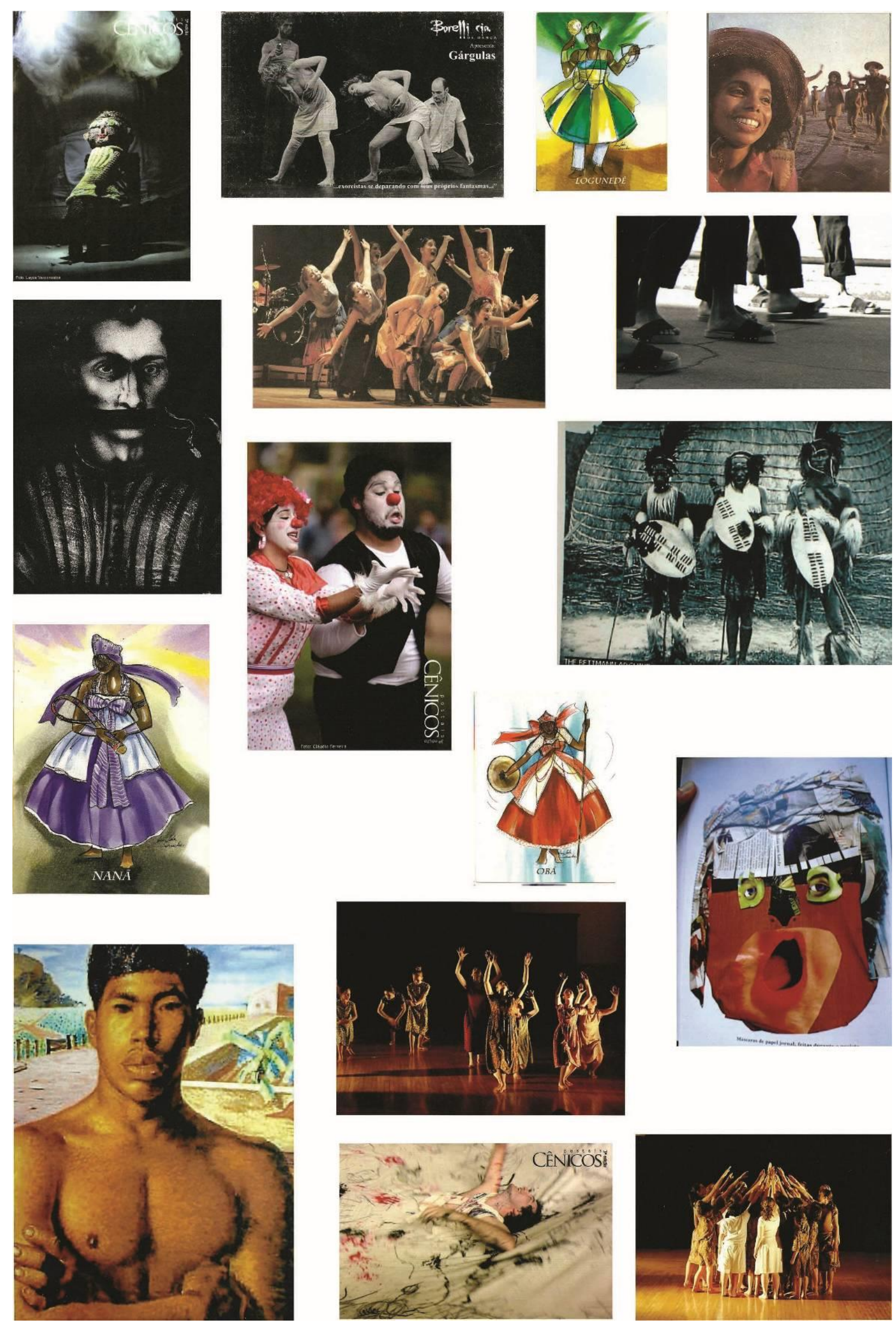

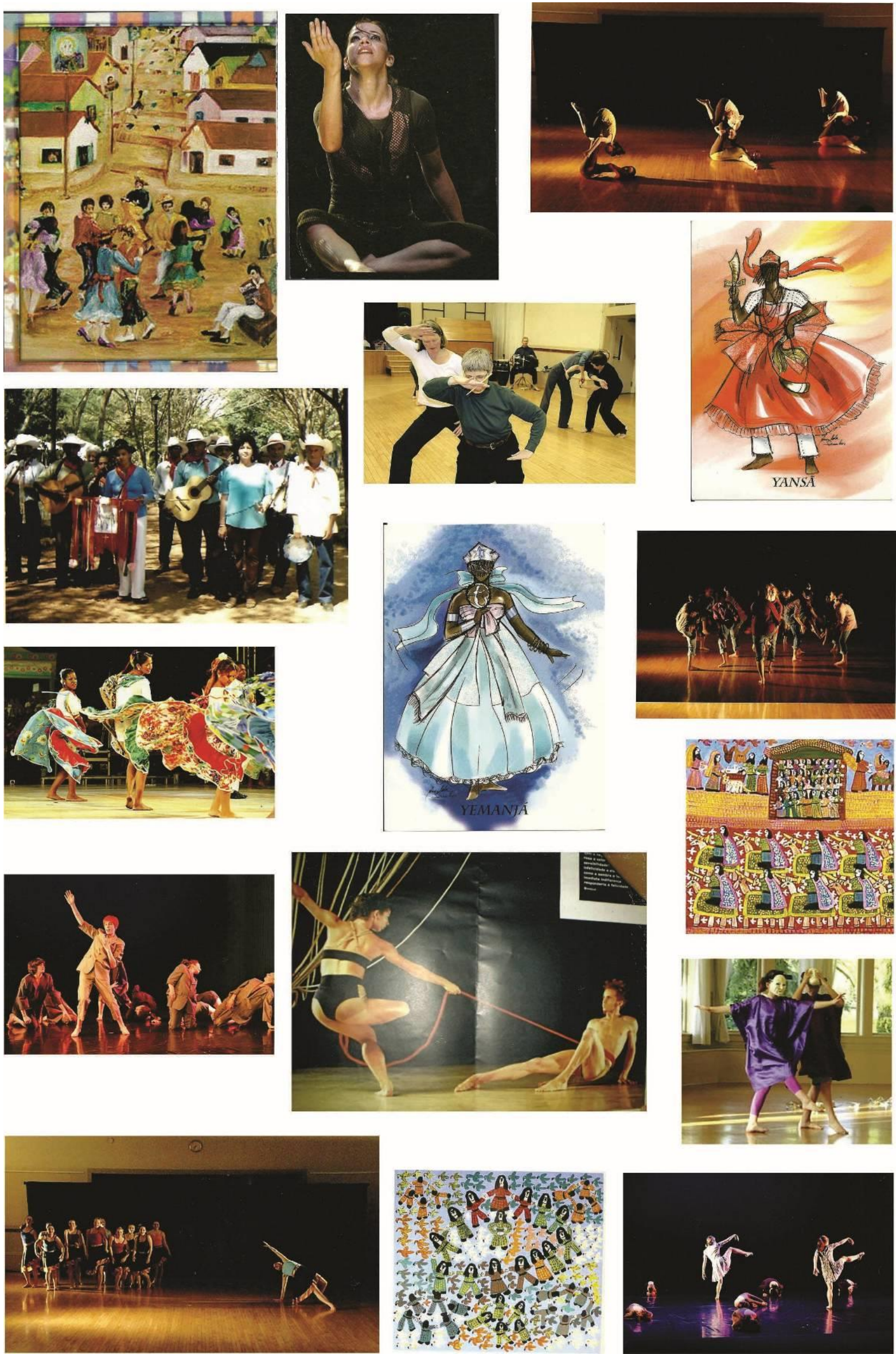

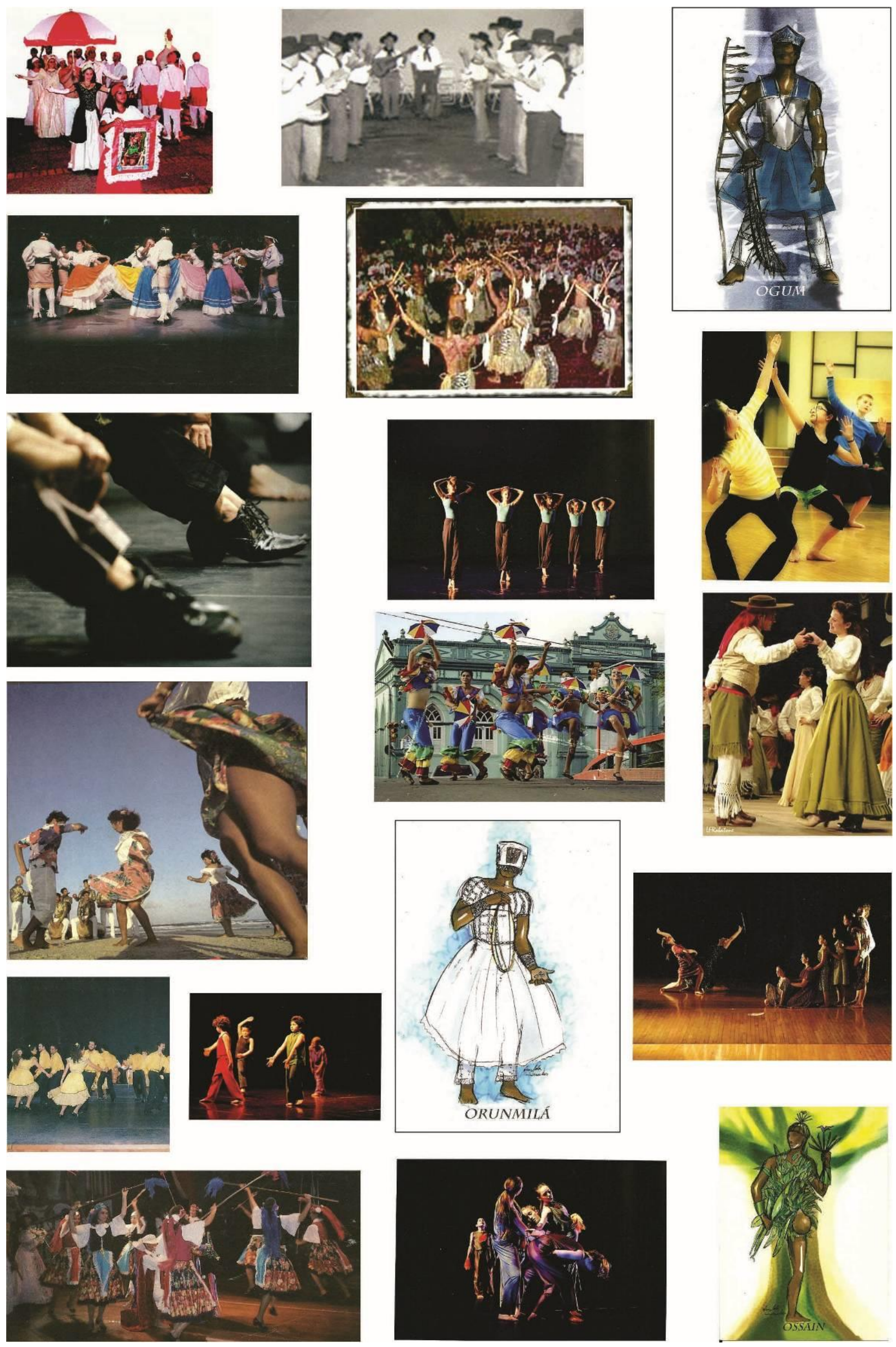

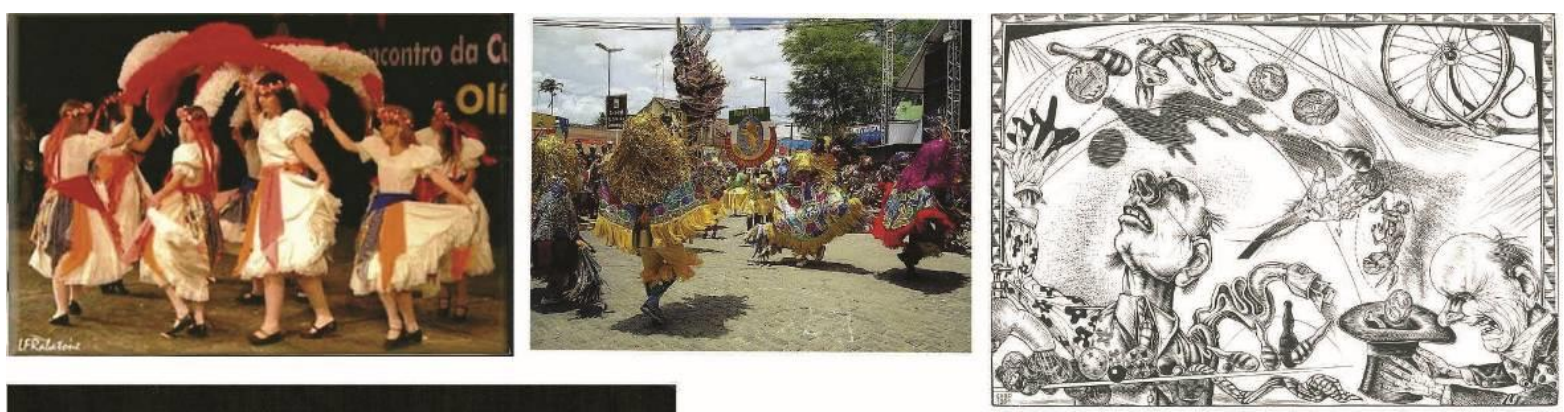
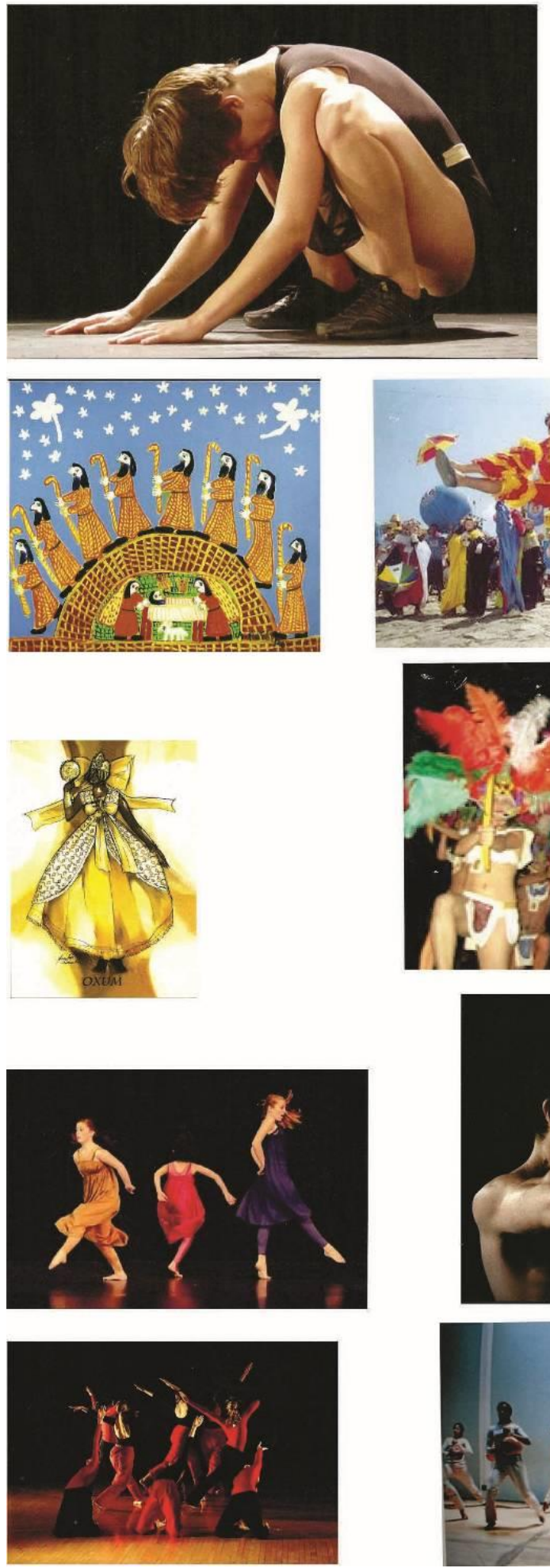
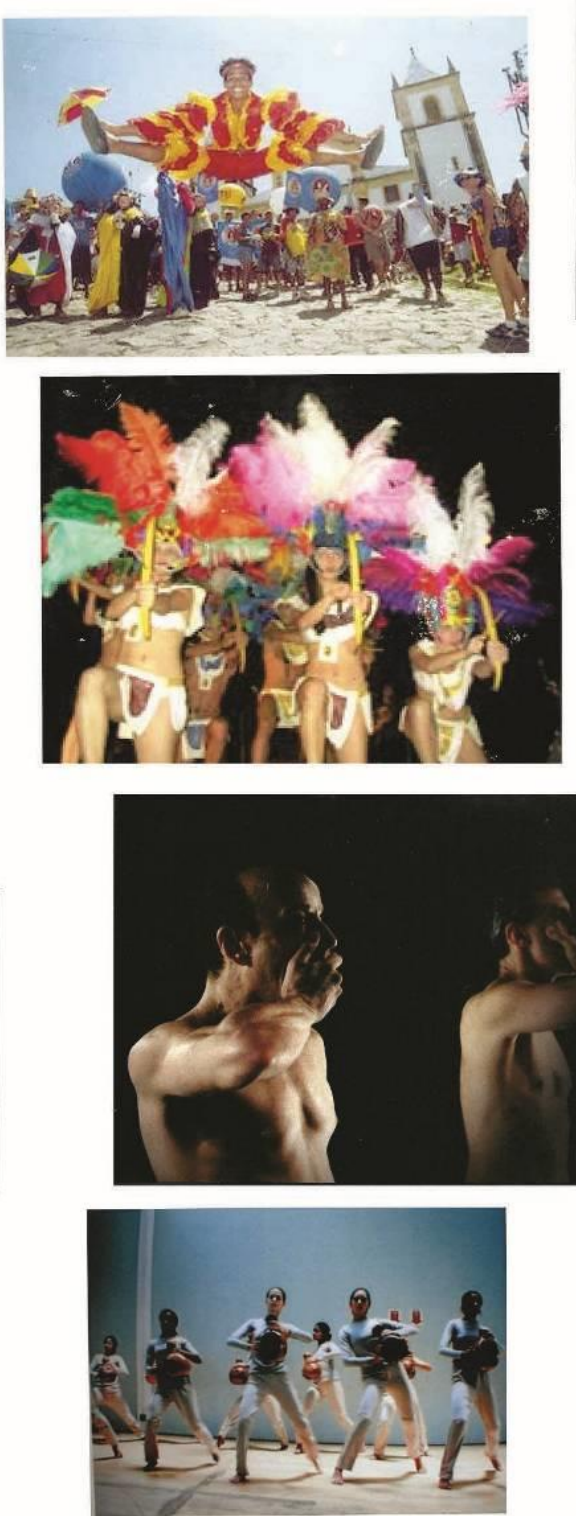
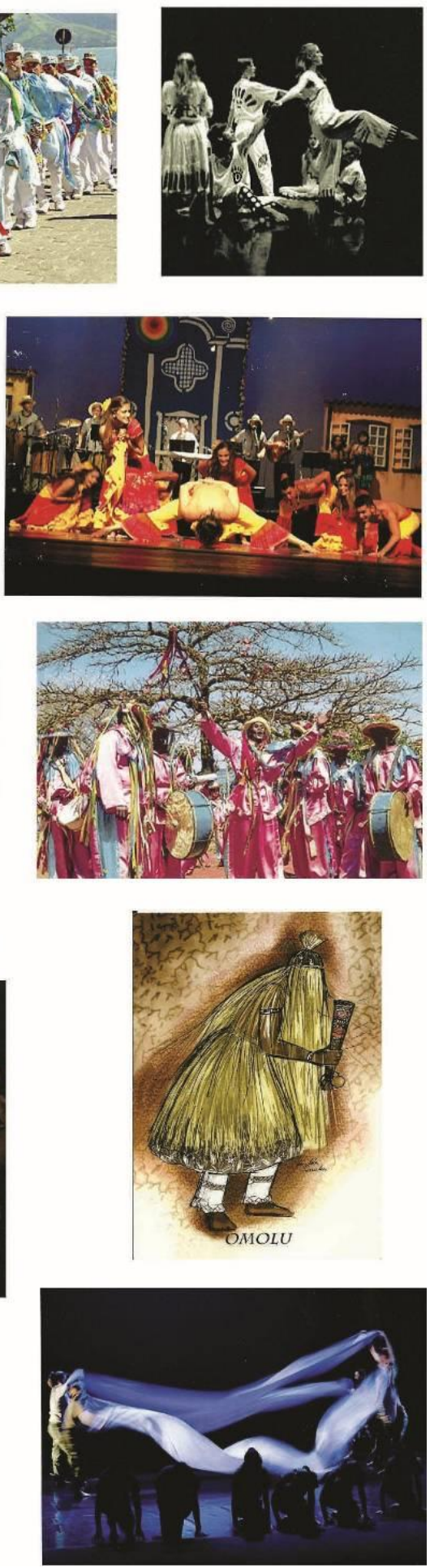
ANEXO II

Fotos da Exposição

Fonte: integrantes do grupo 

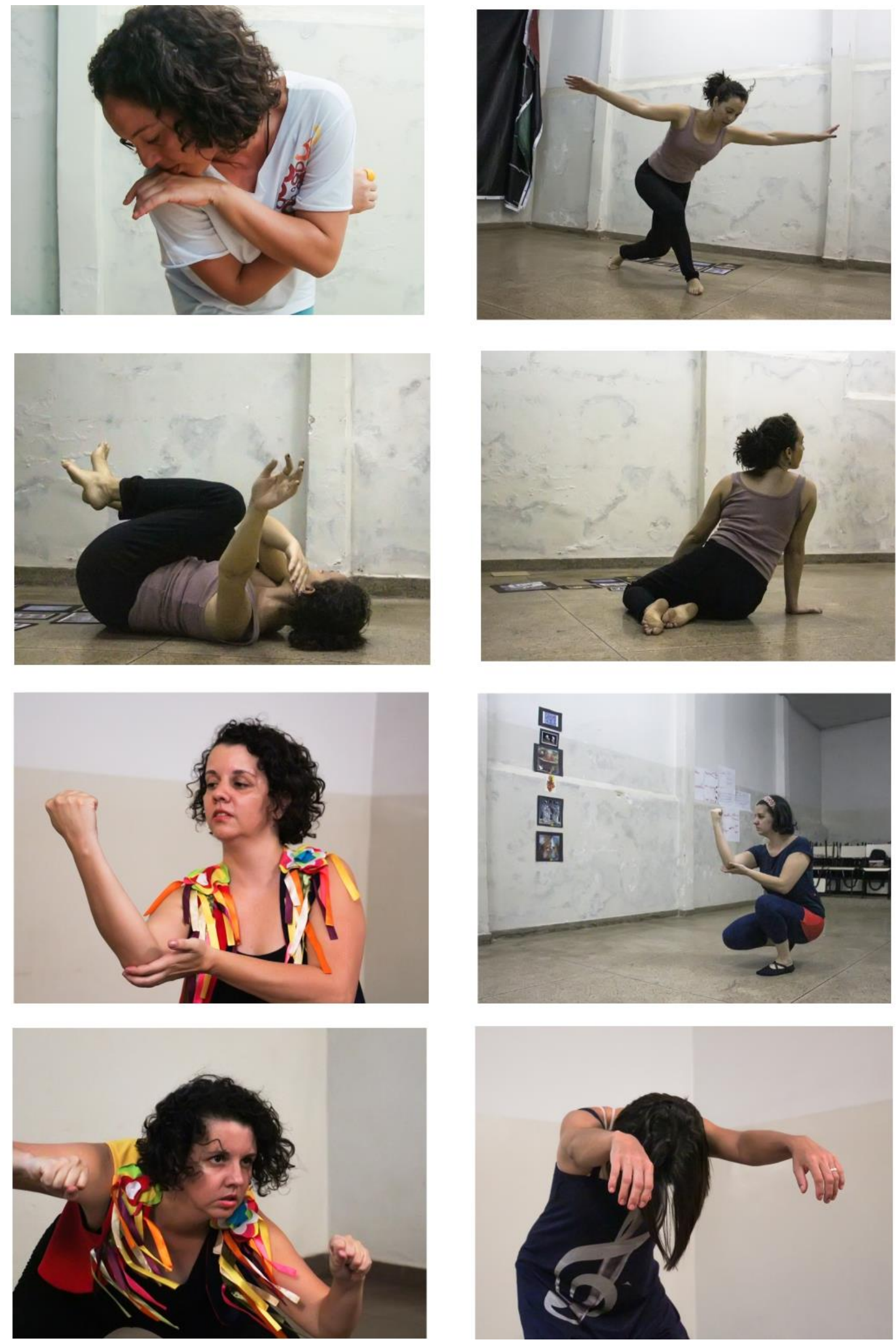

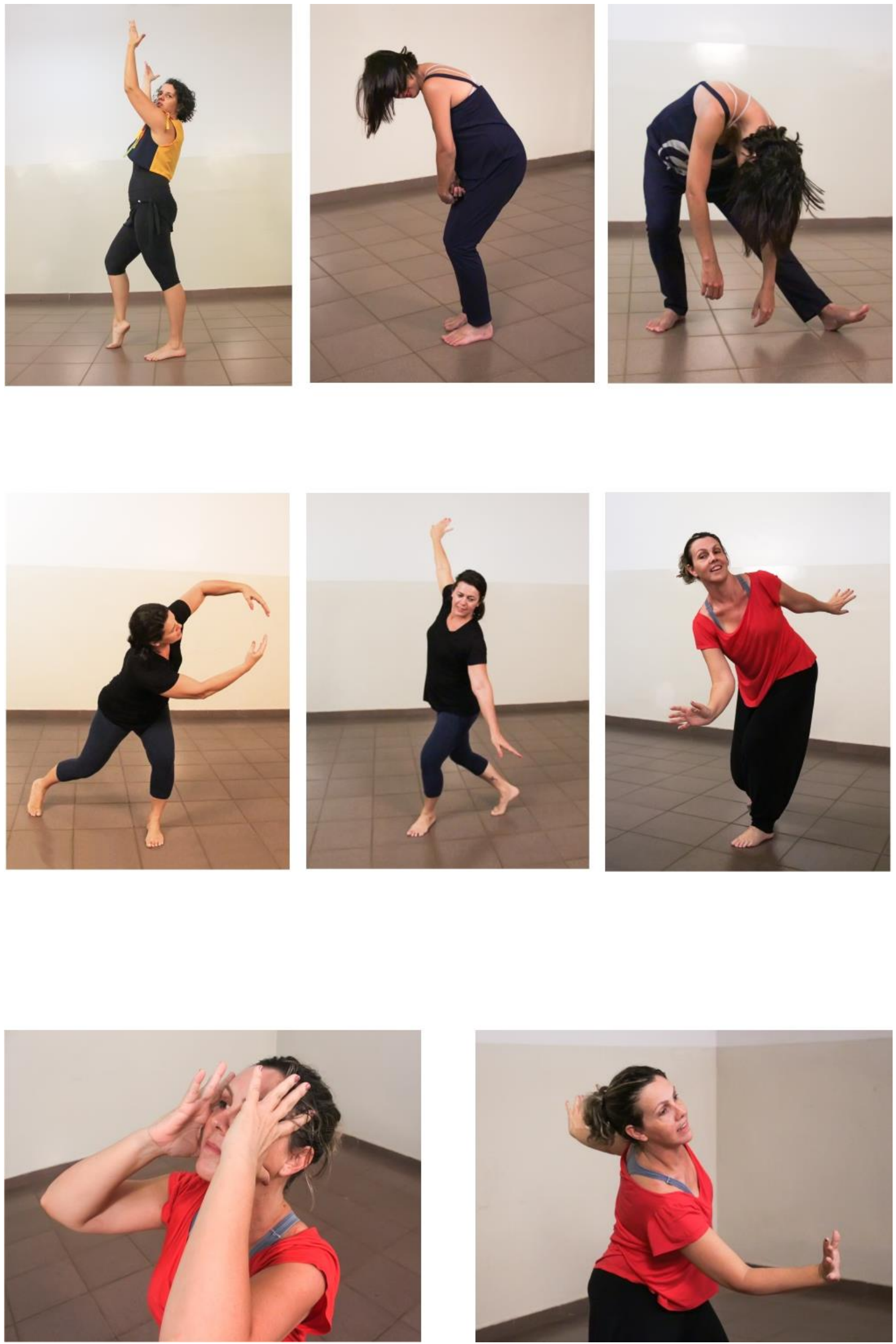

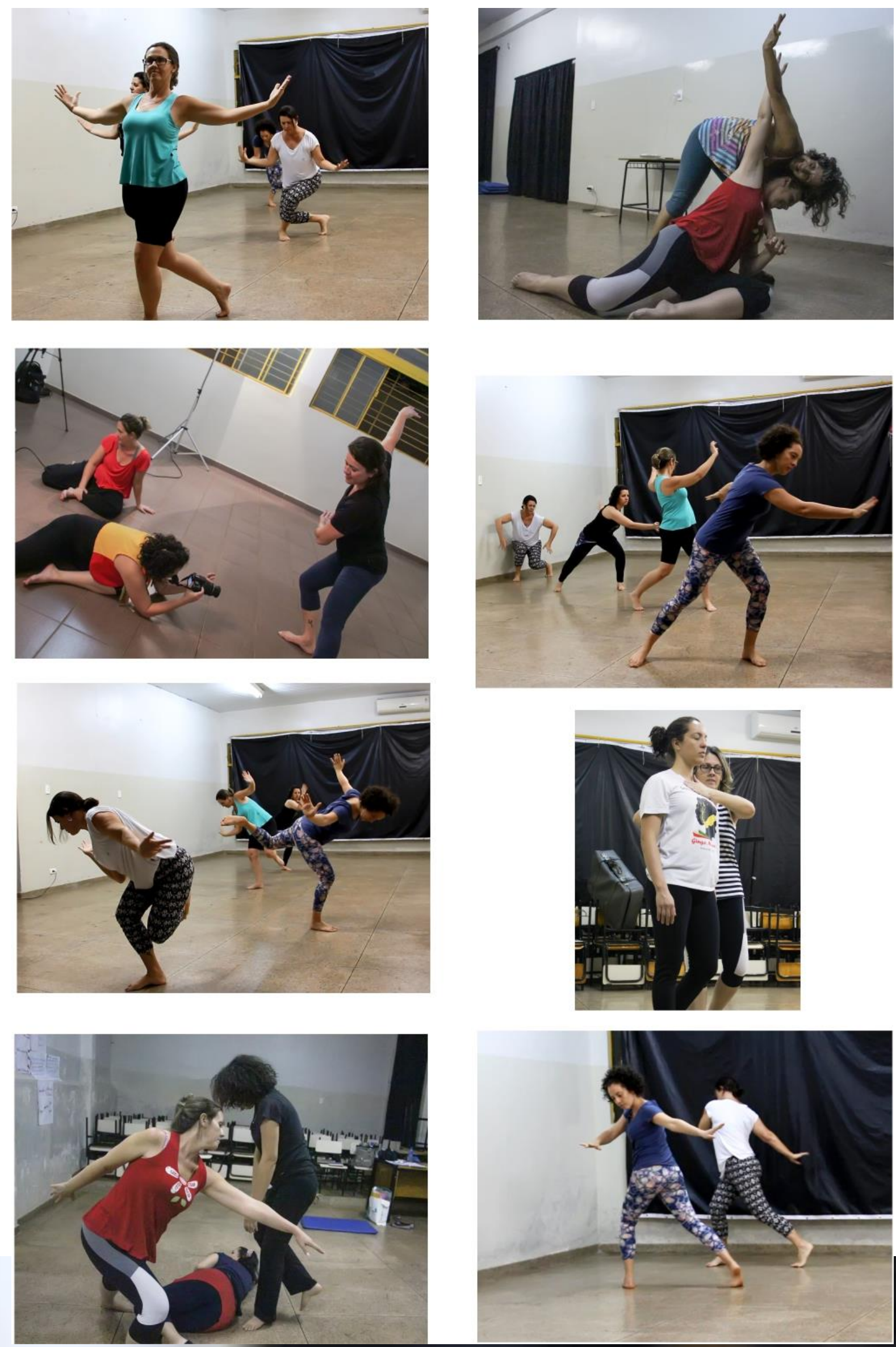
